\title{
The Lines of Concession 9 Part Lot 5: An Imagined Architectural Project on the Skootamatta River
}

by

Jessie Fyfe-Loose

A thesis submitted to the Faculty of Graduate and Postdoctoral Affairs in partial fulfillment of the requirements for the degree of

Master of Architecture

in

Architecture

Carleton University

Ottawa, Ontario

(C) 2014, Jessie Fyfe-Loose 


\begin{abstract}
This thesis attempts to understand 'lines'; lines on a specific site (site-lines) and how the architect responds and reads those 'sight-lines'. Even those lines that are visible but not seen, due to their ubiquity or our habitude. Lines that may seem permanent, transient, seasonal, narrative, temporary or metaphysical.
\end{abstract}

The site is to be found on the Skootamatta River in the township of Elzevir in the Province of Ontario, Canada. The plot of land can be seen from that impossible view, bird's eye, as a slightly irregular rectangular patch in a quilt of others seemingly just like it. On the official land registry map it is called Concession 9 part Lot 5.

This thesis will investigate the types of lines found on Concession 9 part Lot 5 to inform a reading of the site that provides the architect with considerations of the land beyond that of the objective survey that is often preliminary to design. The resultant 'maps of consideration' are made of the layers of lines and will influence the design and build of a small intervention where the invited and uninvited may retreat to share their stories if they are moved to do so. 


\section{Acknowledgements}

I could fill pages with the names of those who have encouraged me through their words, acts of kindness, support, and guidance. I will endeavor to thank them all in some way. I will use these few pages to thank and acknowledge those who have shared this project with me most closely.

For my partner in life, Matt, for how we celebrate our lives together and how he supports the way I see the world. None of this is possible without him. He and our two beautiful daughters fill my heart everyday and make my life such a loving one.

Federica Goffi has been my mentor since the first year of my studies and my admiration for how she looks deeply and encourages all manner of considerations only grows. Her guidance and insightful comments, what I affectionately call, 'her clues', have allowed me to explore and find my own way in architecture for which I am very grateful.

Claudio Sgarbi challenged my thinking with humour and encouraged me to approach all projects with humanity and delight. Roger Connah graciously invited me to be deschooled and through his writing, thought filled editing, and by way of example has showed me there is life after architecture. 
I would also like to thank my studio brothers Mike, Kyle, Trevor, Amir and Andrew without whom our unique studio culture would not have been possible or nearly as much fun.

The writing of this thesis came after the talking with Ryan. Much talking. And drawing. Maps of consideration found their origins in work we had done together in an earlier studio. We called them 'Sensation Maps' and it was the first time I realised that a site plan could help me consider the site differently and found that dialogue was perhaps my method of understanding. Through questions and more questions he helped me find my way to the words about the site that were in my own heart and the courage to write down the dialogues I had been having with the land in my head. I will look forward to more of his questions.

Finally, for all those who love and share that dark fast flowing river: my brothers David and Mac, Lora, Linda, Michael, Dan, Julia, Griffin, Esta, Kristin and their families. And especially for my parents who brought me to the Skootamatta and made it a part of me.

All errings on the wondering path are my own. 
"These trees are magnificent, but even more magnificent is the sublime and moving space between them, as though with their growth it too increased."

Rainer Maria Rilke 


\section{Table of Contents}

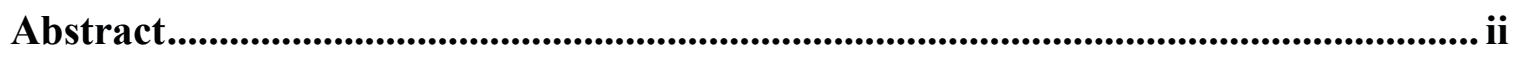

Acknowledgements ............................................................................................................................ iii

Table of Contents ........................................................................................................................... vi

List of Illustrations................................................................................................................ viii

1 Chapter: Finding Site ........................................................................................................... 1

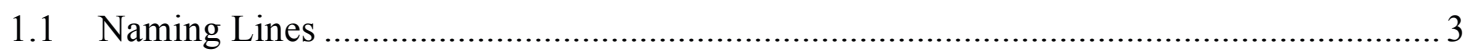

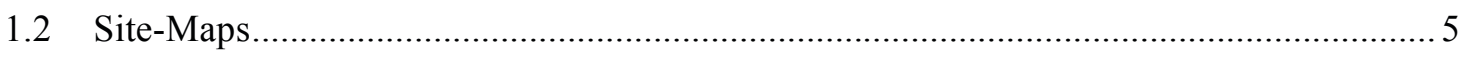

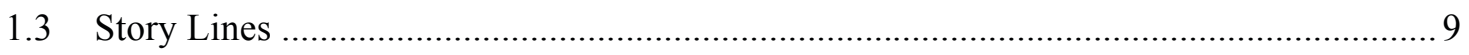

1.4 Storylines: Non Pictorial and Fictional / Factual Telling ........................................... 11

1.5 Storylines - Non pictorial Telling - Then ............................................................. 13

1.6 Storylines - Fictional / Factual Telling - Then ......................................................... 16

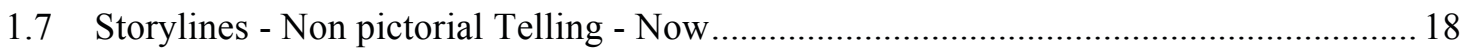

1.8 Story Lines - Fictional/Factual Telling - Now ....................................................... 20

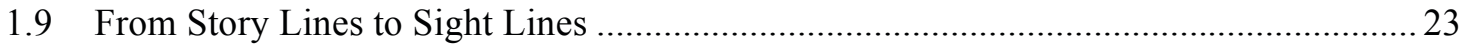

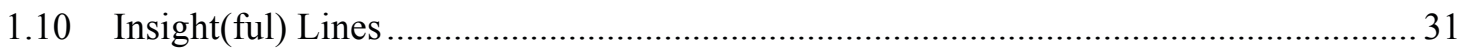

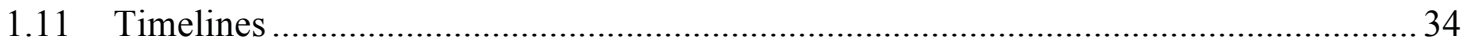

2 Chapter: The Act of Making a Line ............................................................................... 38

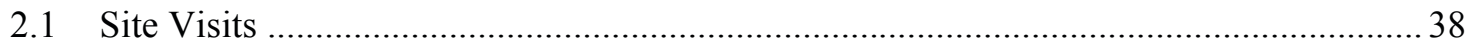

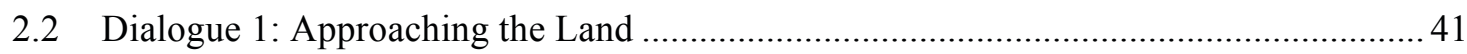

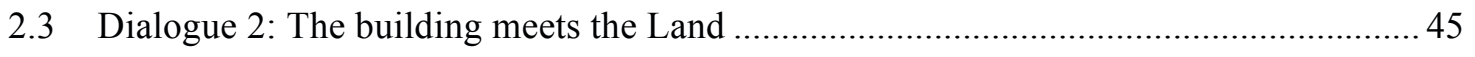

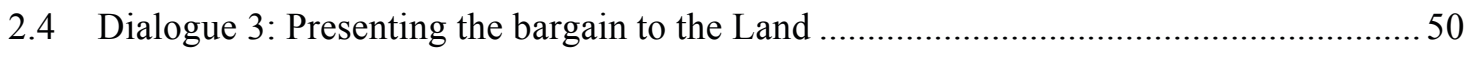

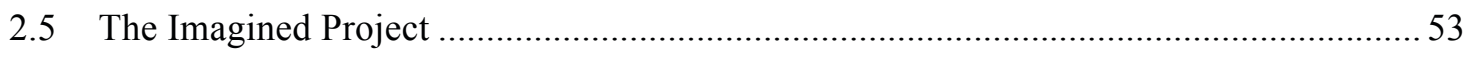

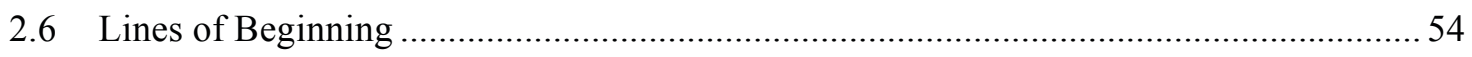




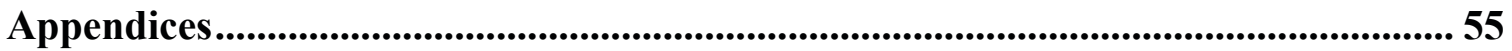

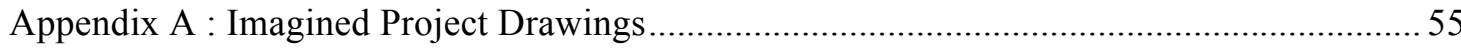

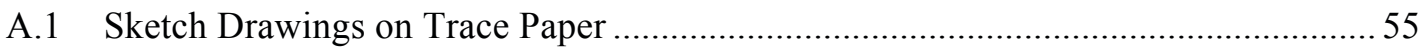

A.2 Working Scaled Drawings on Mylar Paper: Considerably Altered Site Plans ........... 71

A.3 Working Scaled Drawings on Mylar Paper: Ground Plan ......................................... 74

A.4 Working Scaled Drawings on Mylar Paper: Elevations .......................................... 75

A.5 Working Scaled Drawings on Mylar Paper: Section ................................................ 78

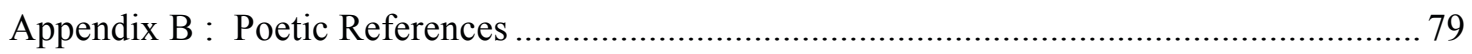

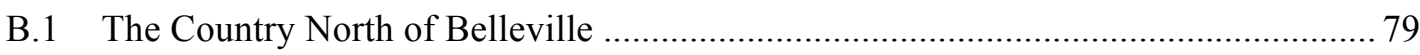

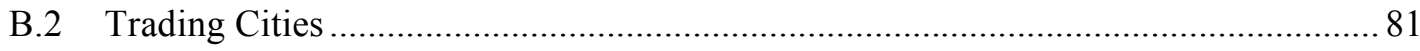

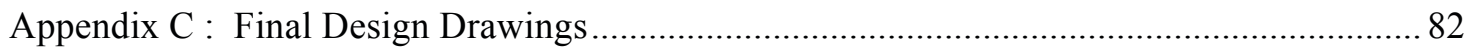

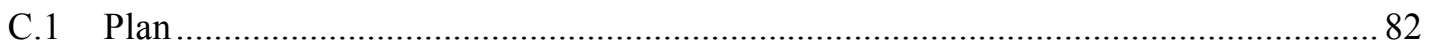

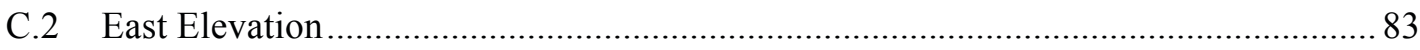

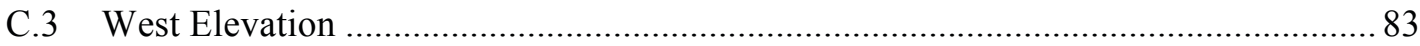

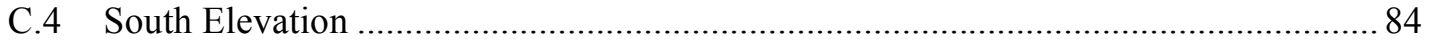

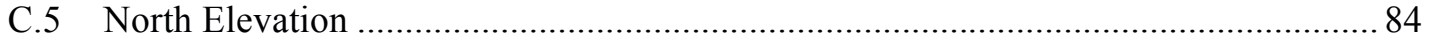

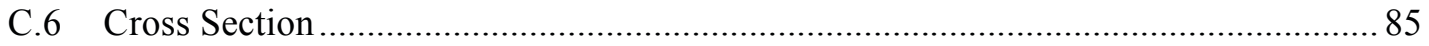

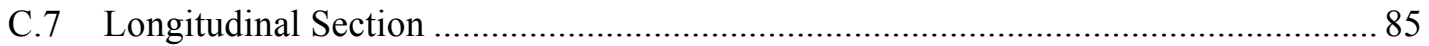

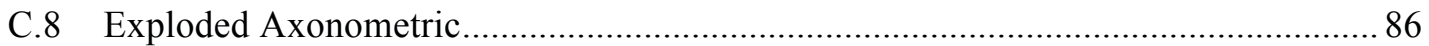

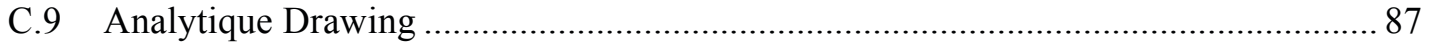

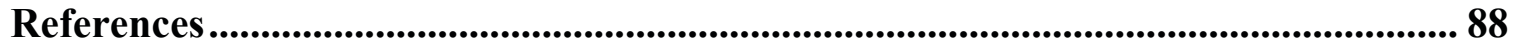




\section{List of Illustrations}

Illustration 1: Forsaken Garden 1909, from On Modern Art, Paul Klee....................2

Illustration 2 Lines: Storylines, Sight Lines, Insight Lines and Timelines.....................4a

Illustration 3: Map of Consideration - Without Scale.............................6a

Illustration 4: Greenland Coastal Maps, from David Turnbull, Maps are Territories........7

Illustration 5 Maps of Consideration - Layered and Without Scale ........................ $8 \mathrm{a}-8 \mathrm{~b}$

Illustration 6 Kleinstuber Family Photograph 1910...............................................11a

Illustration 7: Peter Zumthor, Bruder Klaus Field Chapel..........................12

Illustration 8: Skootamatta Landscape: Photographs ...............................................18a

Illustration 9: Carl Schaefer, Ploughed Field...................................22

Illustration 10: Sverre Fehn, The Hedmark Museum................................27

Illustration 11: Giordio de Chirico, Square with Ariadne........................... 30

Illustration 12: John Hejduk, Berlin Night.....................................32

Illustration 13: Robert Rauschenberg, Erased de Kooning Drawing..................33

Illustration 14: Dialogue 1 Site Visit Collage: Mixed Media ....................................45a

Illustration 15: Details of Land with Sketches - Mixed Media......................47a and 47b

Illustration 16: Dialogue 2 Site Visit Approach Photographs .....................................50a

Illustration 17: Dialogue 2 Site Visit String Series: Photographs...................... 50b - 50c

Illustration 18: Dialogue 3 Site Visit Collage: Photographs.......................................52a 


\section{Chapter: Finding Site}

The artist Paul Klee begins his famous Pedagogical Sketchbook with the concept of " $A n$ active line on a walk, moving freely, without goal. A walk for a walks sake. The mobility agent is a point, shifting its position forward." If you move a point, you get a line, and if you move the line you get a plane. This basic understanding gives you three kinds of mark-making, but doesn't the line offer much more?

In architectural drawing, even the faintest of lines can be dense with meaning. What are those meanings? What is in the line? What lines can be found on a specific site and what do they tell us? How can architects respond to what the lines have to say?

We speak also of site-lines and sight lines. This thesis offers an investigation into the site's lines in their many forms, traces, threads, trails, and tracks. What is their capacity to be additive, or reductive? What creates a surface, which can then be ruptured, producing cuts, cracks and creases.

In a 1924 lecture titled Über Moderne Kunst ('On Modern Art') Klee explains the need to resist the confinement of painting to only that which is visible. "Art does not reproduce the visible, rather, it makes visible." ${ }^{2}$ In the context of architectural marking and image making the writer, critic and artist John Berger echoes this observation and adds that "We

\footnotetext{
${ }^{1}$ Paul Klee, Pedagogical Sketchbook (London: Faber and Faber, 1953), 16.

${ }^{2}$ Paul Klee, On Modern Art, lecture held at Paul Klee's exhibition at the Kunstverein in Jena on 26 January 1924. See also the 'Curator's Talk' by Matthew Gale, The EY Exhibition: Paul Klee - Making Visible, Tate Modern, January 202014.
} 
who draw do so not only to make something visible to others, but also to accompany something invisible to its incalculable destination." ${ }^{3}$ This thesis explores what we might term the particular invisibles that inhabit a selected plot of land on the Upper Flinton Road, along the Skootamatta River in Ontario. How can we 'make visible' the story-lines of this patch of earth, rock and life?

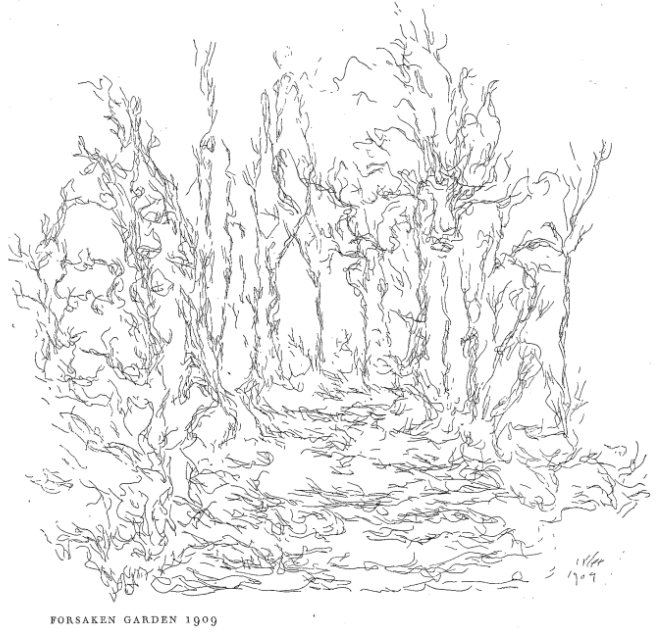

\section{Illustration 1: Forsaken Garden 1909, from On Modern Art, Paul Klee ${ }^{4}$}

What the layers of lines reveal will inform the design of the project that could be imagined to rest on it. The reading of these lines will also suggest their erasure, the possibility of their un-building, through a dismantling or removal by way of deterioration and weathering. What traces would be left to mark what was imagined there? And what would the fragments reveal to us?

This is the story of a site that is real and a project that is a fiction.

\footnotetext{
${ }^{3}$ John Berger, Bento's Sketchbook (London: Verso, 2011), 9.

${ }^{4}$ Paul Klee, On Modern Art (London, Faber and Faber, 1966), 10.
} 


\subsection{Naming Lines}

How do we now turn to a typology of lines, how can they be named, considered, differentiated and what would be learned from this exercise? Tim Ingold, the social anthropologist, has made a cross cultural and comprehensive study of traces and mark making, including lines. ${ }^{5}$ Each line, he writes, embodies in their formation a certain way of knowing. In the process of making an architectural drawing a diversity of lines are employed from diverse sources. Would our drawings then not have those multiple ways of knowing instilled in them? Paul Emmons and Carolina Dayer have written that the act of architectural drawing is a performance. There is a communication between the mark and mark making. The form of the drawing is discovered through the body as it is drawn. ${ }^{6}$

Ingold broadly categorizes traces into one or other of two kinds. They are either additive or reductive. Traces that are additive would be charcoal on paper or pigment on stone. Traces that are reductive are lines that are scratched, scored or etched into a surface; worn wood, clay from the river bank dug for hidden clams, bark of trees with teeth marks. These include traces of animals appearing as paths or tracks as an imprint is made with the wear and tear of many feet.

${ }^{5}$ Tim Ingold, Lines: A Brief History (Oxford: Routledge, 2007), 45.

${ }^{6}$ Carolina Dayer and Paul Emmons article argues that the form of the drawing is discovered as it is drawn with the body. Marcia Feuerstein ed., Architecture as a Performing Art, (London: Ashgate, 2013). 
There is also a class of line that is caused by ruptures in the surfaces themselves creating cracks, observed in breaking ice, dead wood and the bark of tress as well as creases like folds of skin in our hands. A rupture in a surface also creates cuts. For Ingold cutting is also an act of writing. Similar to another class of line, 'ghostly lines', which are visionary or metaphysical as a kind of unwritten line. Examples like constellations, which are invisibly connected, or the persistent use of latitudinal and longitudinal lines on maps and globes are ghostly lines. These invisible lines are necessary as only by creating them can we tell stories about them. These then become storylines.

In some form all of these trace types exist in and on Concession 9 Part lot 5.

The following section investigates each of these line types in turn although there is much intersection. $^{7}$ Narrative lines or storylines are both the written and unwritten stories that have entered the consciousness of the architect. Sight Lines are the additive and reductive traces that can be seen and felt with the body. Insight Lines are ghostly lines that are dashed, erased or signify that which was and is no longer or that which will be in construction or after. Timelines overlap with all other lines. They are invisible and nonlinear leaving changes as their mark. Changes due to cycles of moon and sun, seasons, the calling up of a vivid memory or the faded echo of one. Timelines are at work when marks are left on materials as they change through weathering and deterioration. The elements in the landscape (both natural and fabricated) demonstrate the long arc of time

\footnotetext{
${ }^{7}$ See Illustration 2 Lines: Storylines, Sight Lines, Insight Lines and Timelines, p.4a.
} 
and bear witness to the changes, both those that occurred before memory and those that will be endured in future. Timelines may represent history in the sense that history is what we have been through, what we are in now and what is as yet incomplete. ${ }^{8}$ In Chapter 2 timelines will also serve as a way to engage with the idea of site visits. The episodic visits to Concession 9 Part lot 5 , which also make ghostly and invisible lines until they are recorded in some meaningful way. ${ }^{9}$

All of these layers of lines will provide the architect with a reading of the site that will in turn influence her decisions.

\subsection{Site-Maps}

What does it mean to consider the site? In the case of Concession 9 Part Lot 5 the multiple meanings and usages of the word 'consideration', from the Latin considerare, may be instructional here. In one sense the verb 'to consider' means to examine, to keep in mind, to take into account something or someone. To consider, then, is the process of giving careful thought, and invokes the feeling of a beholding, a looking at something or someone with thoughtfulness, requiring meditation and deliberation. When something is considered it becomes a reason or grounds for a (possible) decision. To consider may also result in a sympathetic regard or an attentive respect and therefore an opinion based upon reflection. In another sense, in contractual law for example, a consideration is

\footnotetext{
${ }^{8}$ David Leatherbarrow, Eric Parry Architects (EPA), lecture (http://vimeo.com/77483578
} Accessed May 2014) September 2013 London. 
something given in payment or recompense for something done. All of these meanings are embedded in 'maps of consideration' for Concession 9 Part Lot 5.

How to read the site? Perhaps first the question must be, how to present the site for it to be read? Or even, how do we presence ourselves at the site, what in-sight do we have? How can we use our bodies to read a site? What other tools are available? What kind of mapping or site analysis could provide the information from which critical considerations and responses will follow? From which point of view shall the site be revealed? What does it mean, what does it require to be truly present at a site and capture the sense of place?

The point of view is of consequence in the construction of a map. The mapping of the site being the first step in this process of line finding, line making and line reading is also of consequence. If in the first place a theoretical understanding, meaning objective and distanced, is undesirable for the task set here what kind of map then is necessary to orient, inform and frame the architectural proposal? ${ }^{10}$

In Maps are Territories David Turnbull questions what maps are, as well as how they function, and attempts to explain the fundamental role space plays in ordering our knowledge of the world. This ordering is not without its tensions. Two general characteristics are outlined: "Firstly, maps are selective: they do not, and cannot, display

\footnotetext{
${ }^{10}$ See Illustration 3 Map of Consideration Without Scale, p. $6 a$.
} 
all there is to know about any given piece of the environment. Secondly, if they are to be maps at all they must directly represent at least some aspects of the landscape." ${ }^{\prime 1}$

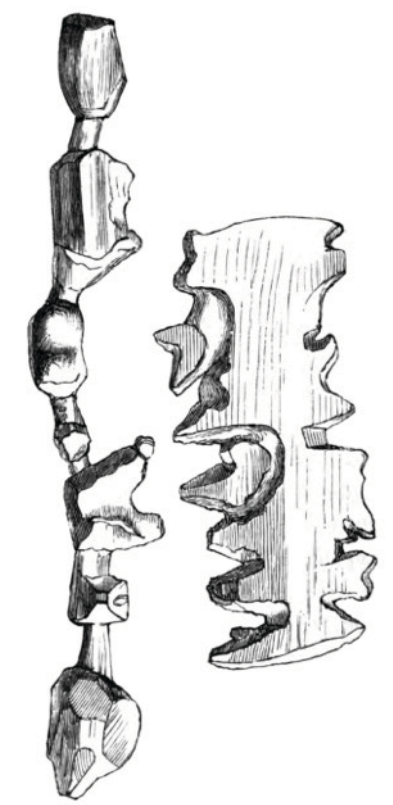

\section{Illustration 4: Greenland Coastal Maps, from David Turnbull, Maps are}

\section{Territories $^{12}$}

The types of representation can be further categorized into two subtypes: iconic representation pertaining to the direct portrayal of "certain visual aspects of the piece of

${ }^{11}$ David Turnbull, Maps are Territories, (Chicago: University of Chicago Press, 1989), 11. The map as metaphor is so persuasive and pervasive and is always selective. "The mapmaker determines what is, and equally importantly, what is not included in the representation... what is on the map is determined not simply by what is in the environment but also by the human agent that produced it."

${ }^{12}$ Ibid. These were three dimensional, carved maps that were used for teaching navigation and kept in canoes. 
territory in question" and symbolic representation, which employs "purely conventional signs and symbols, like letters, numbers or graphic devices." ${ }^{13}$

Turnbull arrives at a working definition of a map as "a graphic representation of the milieu, containing both pictorial (or iconic) and non-pictorial elements." This definition captures the inherent hybridity of maps; they may contain the spatial understanding of variables such as concepts and events, as well as landscape and scale, all from a select and privileged conceptual scheme. ${ }^{14}$

It is this hybrid and considered nature that may allow for a reading of the site that will give vivacity to the image-making that is to follow in this project. ${ }^{15}$ Perhaps resisting a flattening of the perceptible and imperceptible contents of the site and allow the lines these hybrid qualities. Thereby representing both pictorial and non-pictorial elements the most instructive of which may be the lines that result from stories. In order for Concession 9 part lot 5 to become a site for architecture someone has to draft a story.

\footnotetext{
${ }^{13}$ Ibid. p. 12.

${ }^{14}$ See Illustration 5: Map of Consideration - Layered and Without Scale, p.8a.

${ }^{15}$ Elaine Scarry. Dreaming by the Book, (Princeton: Princeton University Press, 1999), p.6. Scarry argues that "the imagined object lacks the vitality and vivacity of the perceived one; it is in fact these very attributes of vitality and vivacity that enable us to differentiate the actual world present to our senses from the one that we introduce through the exercise of the imagination." P.3. This phenomenon, she claims, is true of the visual arts but argues that the verbal arts in contrast somehow do "acquire the vivacity of perceptual objects". P.5. The book is then dedicated to tracing the ways in which this occurs.
} 


\subsection{Story Lines}

Perhaps also we can consider multiple storylines, with multiple authors all feeding into the site, into the imagination. If we continue with Turnbull we see that maps are actually pictures with different and additional functions and purposes to those of perspectival representation. "Pictures may sometimes be entirely subjective, but maps, to be capable of transmitting information, have to be intersubjective." 16 This leads us to ask just what is an intersubjective approach to the mapping of the project site: multi-perspectival representations, a series of pictures rather than maps, a series of stories rather than pictures?

Let us turn to the narrative line again. In a lecture titled Buildings Remember: Spaces as Stories, David Leatherbarrow echoes James Joyce and claims that places remember. ${ }^{17}$ They remember events as memory is placed in places, things and the human body. Buildings can make stories; plans are like plots. There is a coupling found in the architectural plan of both historical and fictional dimensions and they must both exist if there is to be coherence in the story. The events in the story, that move the plot along, like the plan of a building, must be causal not episodic: one event because of another, not one after another. ${ }^{18}$

\footnotetext{
${ }^{16}$ Turnbull, p.12.

${ }^{17}$ This note was hand written in the margins of James Joyce's notes for Ulysses. Notes taken during the attendance of the lecture at Confabulations: Storytelling in Architecture at Virginia Tech, Washington, Friday March 282014.

${ }^{18}$ David Leatherbarrow, lecture titled Buildings Remember: Spaces are Stories delivered at the Confabulations: Storytelling in Architecture Symposium March 28, 2014 at
} 
With this in mind how might the site of Concession 9 part lot 5 and an imagined plan be represented as a story with such potential? This is a representational challenge that begins with the site plan and an alternative to the more objective architectural site survey that concerns itself with location and physical characteristics like topography and road access or variations in wind and sun exposure. ${ }^{19}$ To survey something it must be distant from one's normal experience, as Paul Ricoeur would describe as “distant in time or some other place. ${ }^{, 20}$ In contrast something that is latent or implicit cannot be surveyed in this way. It is something that is not directly visible that may give rise to a rich sense of the place.

This thesis offers an alternative intersubjective site view comprised of layered stories, pictures and maps providing more than what can be objectively observed. ${ }^{21}$ The result

Virginia Tech Washington. See Aristotle Poetics (Chapters 7 -9) and the criticism of episodic plot. Aristotle, trans. Malcolm Heath (Penguin Classic, London 1997).

${ }^{19}$ Jane Rendell the architect and educator compares the term site-specific in art discourse as being a "critically informed response to a site," to architecture where the term site "tends to define a location that can be measured in terms of physical rather than cultural qualities, such as geometry, geology and aspect." Art and Architecture: A Space Between. (London: I.B. Tauris and Co. Ltd., 2006), 52.

${ }^{20}$ See Paul Ricoeur, History and Truth (Northwestern University Press, 1965) 21. David Leatherbarrow describes the survey as a dimension of architectural work that "inaugurates the design". He expands the idea to mean the "sense of conditions under which a project is possible." He explains that what we conventionally and casually call surveying he considers to "similar to historical understanding" that is subjective. See Eric Parry Architects (EPA) (http://vimeo.com/77483578 Accessed May 2014) September 2013 London.

${ }^{21}$ Intersubjectivity in this context is borrowed from an understanding of the rejection of the subject-object dichotomy in the work of Maurice Merleau-Ponty and the possibility of a genuine intersubjectivity, where multiple minds can share meanings based on their 
being a site consideration that informs the architectural plan and in return a plan that informs the composition of the site. ${ }^{22}$

\subsection{Storylines: Non Pictorial and Fictional / Factual Telling}

The following narrative compositions include two arcs of time, 'then' and 'now'. Influenced by Turnbull's definition of a map each arc has two components: a nonpictorial telling and a fictional/factual telling. The story telling in the following sections are hybrids of fact and fiction on sliding scales of time. When thinking of the stories images may come to mind and the power of metaphor rises to the surface and can be included in considerate mapping. ${ }^{23}$ In Neuroscience and Architecture, Henry Francis Mallgrave dedicates a chapter to the use of metaphor in the theory and practice of architecture. He explains from a biological viewpoint what occurs when we make judgments about buildings, his research leading to conclusions about the immediacy of our sensory perceptions and that the brain is a "rhythmic and holistic process of neural activity not only imbued with sensory and emotional coloration but also structured by metaphoric pattern making". ${ }^{24}$ There is something neurological and primal at play when

interactions with one another. The Cambridge Dictionary of Philosophy, Edited by Robert Audi (Cambridge: Cambridge University Press, $19992^{\text {nd }}$ Edition), 559.

${ }^{22}$ Carolina Dayer and Paul Emmons: The act of drawing as a performance. The form of the drawing is discovered as it is drawn. Architecture as a Performing Art. Edited by Marcia Feuerstein.

${ }^{23}$ See Illustration 6 Kleinstuber Family Photograph 1910, p. 11a. The Kleinsteubers were one of the original families in the German Settlement in Elzevir Township in the middle of the 19th Century. http://atthemanse.wordpress.com/2013/07/08/what-once-wasphotographs-from-elzevirs-german-settlement/ Accessed May 2014.

${ }^{24}$ Henry Francis Mallgrave, Neuroscience and Architecture, (Wiley Blackwell Chichester, West Sussex, 2011), 185. 
we respond to the archetypal architectural experiences of "color, light and shadow, space, time, water, sound, hapticity, proportion and scale." ${ }^{25}$ Peter Zumthor opens his book Thinking Architecture with the simple phrase, "When I think about architecture, images come into my mind." Mallgrave explains this in biological terms: "For all of the neurological complexity of the brain, the metaphoric activity of the architect is primarily a process of image-making a re-simulation of familiar or associative neural patterns drawn from experience and on occasions bringing something quite new to the result." 26 When experiencing the site through these stories what images of architecture come to mind?

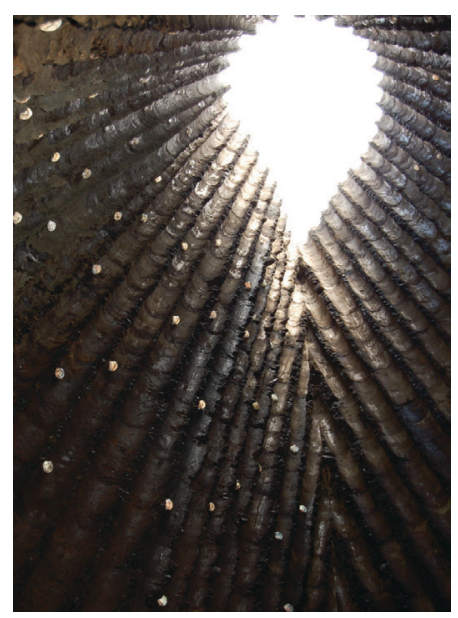

Illustration 7: Peter Zumthor, Bruder Klaus Field Chapel, Germany, 2007, Interior, photo by Samuel Ludwig ${ }^{27}$

\footnotetext{
${ }^{25}$ Steven Holl argues that we respond to these phenomena as their immediacy engages our sensory perceptions. Steven Holl, "Questions of Perception - Phenomenology of Architecture," in Holl, Pallasmaa, and Perez-Gomez, Questions of Perception, 41. See also Mallgrave (2011) p.185.

${ }^{26}$ Mallgrave (2011) P. 184.

${ }^{27}$ Accessed May 2014 from http://upload.wikimedia.org/wikipedia/commons/5/56/WikiWachendorf-Feldkapelle-Himmelsloch02.jpg
} 
The essayist Walter Benjamin famously wrote: "Artisan form of communication does not aim to convey the pure essence of the thing like information or a report. It sinks the thing into the life of the storyteller, in order to bring it out of him again." ${ }^{28}$ The sections below titled Storylines - Fictional / Factual Telling - Then and Now intend to provide enough information to generate the imaginative process but do not foretell an outcome or make a prescription. The sections attempt to provoke an understanding of how to imagine but not what to imagine and to give rise to a design for a building that is not a result of information gathered, but rather a way to sink the thing into the life of the architect in order to bring the drawing out of her.

\subsection{Storylines - Non pictorial Telling - Then}

Concession 9 Part Lot 5 lies in Elzevir Township. Grimsthorpe bound the township in the north, in the east by Kaladar, the south border was Hungerford, and the west was Madoc. The River Scootamatta was a conduit for the red and white pine that was felled in vast quantities until the lumber industry collapsed due to over forestation in the early 20th Century. ${ }^{29}$ In the 1860 s more than 200,000 logs a year were floated to the Ottawa River from tributaries like the Skootamatta. ${ }^{30}$ Competing firms with their "migratory bands of

\footnotetext{
${ }^{28}$ W Benjamin, “The Storyteller”, in Illuminations: Essays and Reflections, ed. Hannah Arendt, (Harcourt, Brace and World, New York), 91.

${ }^{29}$ Jean Holmes, Times to Remember in Elzevir Township, (Madoc Printing, Madoc, 1984).

${ }^{30}$ The current spelling of the river is Skootamatta. There are different translations for the Ojibwa words. One alternative being "burnt shoreline" perhaps as the Paleozoic sedimentary rocks of its shoreline is that of the dark amphibolite of the Canadian Shield. The other is the more widely accepted meaning as "a spilling of stars". Margaret Axford, The Oxen and the Axe, (Cloyne and District Historical Society Second Edition, 2008).
} 
lumbermen" would steward the logs toward the St. Lawrence and then on to Quebec City to be shipped overseas to its single destination, England, and its sole appropriator, the British Navy. ${ }^{31}$

Elzevir was named in 1820, possibly by Lieutenant-Governor Sir Peregrine Maitland, after the famous Elzevir publishing family, active in Holland from 1580 to 1712. ${ }^{32}$ The name is said to mean "elm" of which there were three species in the forests of the township or "firewood" which was plentiful. Two years after its incorporation in 1880 the local directory pronounced it “very prosperous... rapidly settling by an (sic) hardy, industrious population; the immense pineries with which it abounded are rapidly disappearing, like the forest children that were fostered beneath their boughs, and good houses and barns and well-cultivated farms have taken their place. ${ }^{33}$ Early township settlers, mainly Dutch, Irish, English, Scottish and German immigrants, were attracted to the thick forests and then to the fertile land left behind after they were clear cut. ${ }^{34}$ Land was offered for free by Lieutenant-Governor John Graves Simcoe in the land granting

\footnotetext{
${ }^{31}$ This was a term used by the Commissioner of Crown lands T.C. Keefer in a document from 1856 stating their involvement in the lumber trade as necessary but also socially undesirable. Curious to note also that wolves and coyotes were considered in the same document as also a "constant problem".

${ }^{32}$ Gerald E. Boyce. Historic Hastings, (Hastings City Council 1967).

${ }^{33}$ Hastings County Directory (Hastings County), 192

${ }^{34}$ The 1878 Beldon's Historical Atlas describes the forest trees of the township as: white pine, sugar maple, red pine, white spruce, tamarack, hemlock, white cedar, balsam, black spruce, red cedar, six species of oak, three species of elms (including slippery elm), three species of ash, three species of birches, beech, basswood, hickory, bitternut, butternut, balm of Gilead, black cherry, and the red or soft maple. The township took its greatest pride in its huge stands of white pine. "It was cut as if it would last forever." Jean Holmes, Times to Remember in Elzevir Township, (Madoc Printing, Madoc, 1984), 47.
} 
system of 1792 provided the intending settlers took an oath of loyalty, undertook to clear at least five acres, build a house and open a road across the front of their lands. A colonization of road building soon followed. ${ }^{35}$

Nearby villages, Bridgewater, Queensboro and Flinton were given complimentary reviews in the 1879 - 1880 directory and were noted to have made "considerable progress" due to being well placed to take advantage of the 'water-power' for saw and grist mills. The soil was variable throughout the township, some parts fertile and productive, and in others rocky and mountainous. What lay beneath the soil was of special interest as in the belly of the rocks there were minerals: iron ore; copper; lead and mica and for a short time a seam of gold was to be found. ${ }^{36}$

And what of the forest children? Under which particular boughs did they take shelter? How far back does the memory go to reveal the stories of Concession 9 Part Lot 5 ? Perhaps if we squint our eyes and sit very still we can imagine 4000 years before now, before this day. Can we see the hands that lost the spear point made of quartzite found on the Clarke Rawson property, while ploughing a field for oats? ${ }^{37}$

And what of the winter of 1615 that kept Samuel de Champlain from continuing his exploring and voyaging? "The snow was deep, so I spent the winter with the Indians

\footnotetext{
${ }^{35}$ Holmes, p. 8.

${ }^{36}$ Holmes, p. 9.

${ }^{37}$ Holmes, p. 10.
} 
about 80 miles north-west of the mouth of the big river where game was plentiful."

Could the travel have been from Fort Frontenac (Kingston) north to the encampment known to be on a trail between Kaladar and Elzevir Townships and along the

Skootamatta River? The same encampment, which was one day 200 years later, surrendered to the Government of Upper Canada in an agreement reached with the Mississauga Nation of peoples. ${ }^{38}$

\subsection{Storylines - Fictional / Factual Telling - Then ${ }^{39}$}

Dam repairs, devastating fires caused perhaps by chimney spark in which only some furniture could be saved, failed quartz mills, marriages (wife maiden name always in parenthesis), logging gangs with ice in their beards...

Watersheds mapped, beaver dams making water yellow and non-potable, the loss of the elm to Dutch elms disease, loss of virginity in freezing wood sheds, the scoring of the earth in the building of Hwy $7 \ldots$

The sound of crickets...

Ownership and loss, barns sold whole, dismantled and moved during the depression...

Another fire, Mr Frost burned badly about the head and one hand. The contents of the building were saved, except for one horse and one cow...

\footnotetext{
${ }^{38}$ Holmes, Introduction.

${ }^{39}$ These stories are hybrids; they are fiction derived from myth, conjecture as well facts found in historical sources. See: Holmes, Times to Remember. Hastings County Directory; Beldon's Historical Atlas; The Oxen and the Axe; Historic Hastings.
} 
1818, 25 years after the gradual abolition of slavery by the Province a notice appears in the Kingston Newspaper, Bet, a servant and her two-year-old child are demanded to return...it is forbidden to harbor them...

Mail was taken by stage from Belleville to Bridgewater and to Madoc and then to Queensboro. Horses were changed at Latta...

Foundries and tanneries, grinding and milling of grain...corn was brought from as far away as Madoc to be ground...

Snow fell...

Expecting her sixth child Elizabeth arrived in Bridgewater late in 1866. Caught in a blizzard she sought refuge in a lumber shanty...

Rain fell...

Yes and rain dried up...

1879 the only businesswoman in the directory was a dressmaker, Mrs. S. Chase...

Landforms, bedrock, contemplations over railroads, consequences considered and then felt, car loadings dwindling.

A brass bolt - a "land level" which is one of the cement abutments of the old railway bridge is exactly 643.3 feet above sea level...

A swimming hole at the end of the back street where people also watered their horses was a favorite place for him. 
Trains coming into Actinolite station after a snowstorm in $1922 \ldots$ an application for abandonment. ${ }^{40}$

\subsection{Storylines - Non pictorial Telling - Now ${ }^{41}$}

As of January 1st 1998 Concession 9 Part Lot 5 is in the Municipality of Tweed an amalgamation of the former village of Tweed and the former townships of Hungerford, Elzevir and Grimsthorpe. Thirty percent of the Municipality is Crown Land, owned by the province largely for the purposes of forestry concessions. Two percent of the municipality is made up of lakes, rivers and streams of which the Skootamatta is included.

Dammed in two locations the river no longer carries lumber. The 'put-in' is at the bridge in Flinton and it takes two long days of canoeing to traverse the 55-kilometers of flat water and rapids to arrive in Tweed. Take-out is near the parking lot where summer corn and blueberry pies are sold.

Concession 9 Part Lot 5 is bound to the South by the gravel of Upper Flinton Road, to the East by the Skootamatta River forded by a concrete bridge, to the North and West by land not yet sold by Mr. Foster. There is an existing timber frame cottage built with The Pattern Language as a guide on a footprint larger than expected due to the

${ }^{40}$ See Illustration 8 Skootamatta Landscape: Photographs, p.18a.

${ }^{41}$ The content of this section is factual sourced by interviews with the builder architect of the timber frame cottage and log cabin existing on Concession 9 Part Lot 5. 
uncontrollability of dynamite. ${ }^{42}$ A covered passageway beyond the front door connects the timber frame construction to a log cabin. Built at the same time, less than a decade ago, with the pine logs from the plantation across the road and cut with an old circular sawmill that Andy Roys father built and is still in good working order. These two vernacular building types attached using the old Hudson's Bay style with notched channels in the posts and tenons so that they can shrink inside a timber frame that is stable enough to be attached to the main building. The logs are squared on three sides and sit on one another with strips of blue Styrofoam sealing the joints.

During construction there was always a concern that the blue mold might set in so, there was a lot of stacking and restacking of very heavy timbers. In the spring, the bents were put together on the subfloor using 'come-alongs' on nylon straps to pull all the joints tight and square each of the bents before drilling the holes and driving in the pegs. Then there was a day with a crane to lift the bents one at a time and put in the girts. Bents were stacked on top of each other with the North end on top. Crane at furthest reach just tall enough to keep it vertical while stays were roped back up to the pine trees on the ridge. Once the frame was together the youngest member of the team climbed up and tacked a pine branch on the gable end as was and is tradition.

${ }^{42}$ Christopher Alexander, Sara Ishikawa and Murray Silverstein, A Pattern Language: Towns, Buildings, Construction (Oxford University Press, 1977) advocates a design approach by which lay people can resolve design problems. 
The cottage has views of the river and the sound from the rapids and the wind in the trees can be heard from the bedrooms on the second level. There are no windows to the North as if the building is closing one eye and can only see forward to the road or to the East and the river.

With your back to the road facing North with the River to the East you will see there is a fold in the earth. An open top ridge of solid granite rises out of a deep forked ravine behind the timber frame cottage. Beyond the ridge is a pond. Its privacy is in contrast to the rapids and the wide flat rocks near the Bridge that is a favorite swimming hole for local families and the adventurous on long weekends. Here is the best view of the falls and the pond that is made by the river diverted briefly before returning on its way toward the rapids. The pond is edged with trees no older than 20 years; chanterelles, cowslip, ferns and moss all grow here. In the winter with a flash freeze the pond becomes a skating rink.

\subsection{Story Lines - Fictional/Factual Telling - Now ${ }^{43}$}

There are chinks in the rocks around the pool where the machinery of the mill was inserted. Although I haven't looked for them in years they must still be there.

And there was a drowning, too, during a church picnic.

And there are the ashes of some of our dead.

\footnotetext{
${ }^{43}$ The stories captured in this section are gathered from experiences and memories of those who live on and around Concession 9 Part Lot 5.
} 
And the sleeping tree that was so so old but that blew down in a storm. Under that tree the people who built our place once camped.

One bridge was built with logs, only to last the day, a wedding day, at which names of guests were written on river stones.

There is a smell left on the feet of the city dogs after they returned from their roaming, wild about the eyes and panting.

Badminton matches at which some are found always to be cheating...

The sound of crickets...

A bridge named but always referred to by us as Carl's bridge for the man who once painted there...took with him pieces of the Skootamatta River in ink and oils. ${ }^{44}$

Snow falls... snow melts and swells...passing hundred year markers, pictures are taken to document the rise and it is said: 'never seen it that high'...

Daring November or April swims risking hearts missing beats and useless fingers...

Trips to the dump because we are only temporary here... select days to recycle glass, metal and newsprint.

${ }^{44}$ Carl Schaefer was a Canadian regionalist artist and teacher who painted scenes of rural southern Ontario. In 1940 he was the first Canadian to have received a Guggenheim Fellowship for the visual arts. He taught at the Ontario College of Art from 1948 - 1970 and had brought his students to paint from the bridge on the southern property line of Concession 9 Part Lot 5. See: G. Johnston, Carl: Portrait of a Painter (Penumbra Press, 1986); M. Gray et al, Carl Schaefer (Gage Pub, 1977); C. Varley, Carl Schaefer in Hanover (Edmonton: Art Gallery 1980). 
Bridge was built.

Bridge was rebuilt.

If, before you swim, you lie down in the stars of the juniper moss, you can hear the river over the rocks.

Feet on weather worn decking announce arrival and departure.

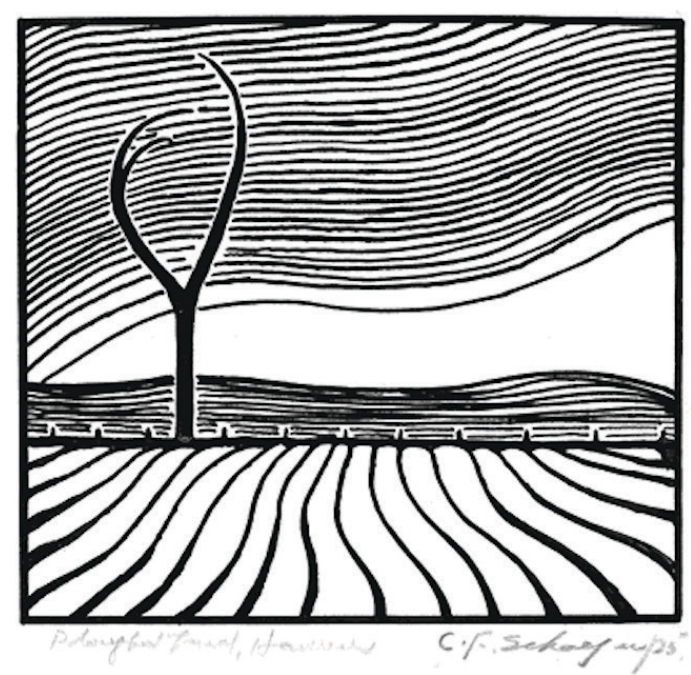

Illustration 9: Carl Schaefer, Ploughed Field, Hanover Drawings ${ }^{45}$

45 Accessed May 2014 from

http://www.penumbrapress.com/galleries/schaefer/artshow2.php?style=print 


\subsection{From Story Lines to Sight Lines}

Story lines present the architect with possible clues to reveal what is latent in the landscape of Concession 9 Part Lot 5. How do we now move from the ephemeral and temporary, the unseen and invisible to lines on a plan?

We know also that there are those lines on the site that are tangible. Lines we see and feel that mark the site. They have a three dimensional quality and we use our sense of sight, touch and hearing in order to become aware of them. ${ }^{46}$ The complexity of lines has corporeality and these lines allow for a phenomenological reading of the site and an understanding that all description is always already interpretation. ${ }^{47}$ One that is partial in two senses: partial in the sense of belonging to a single person's experience and partial meaning incomplete. The site considerations are not a description of the entirety of the site it is incomplete and by virtue of this allows for new possibilities to emerge dislocating any possibility of a singular reading. ${ }^{48}$

\footnotetext{
${ }^{46}$ Edmund Husserl the German philosopher who established the school of phenomenology described the process as: "Focusing our experiencing gaze on our own psychic life necessarily takes place as reflection, as a turning about of a glance which had previously been directed elsewhere. Every experience can be subject to reflection, as can indeed every manner in which we occupy ourselves with any real or ideal objects...through reflection, instead of grasping the matter straight-out - the values, goals, and instrumentalities - we grasp the corresponding subjective experiences in which we become 'conscious' of them, in which (in the broadest sense) they 'appear'. For this reason, they are called 'phenomena'." Edmund Husserl, in 'Phenomenology' for the Encyclopedia Britannica (1927). Revised translation by Richard E. Palmer. See also Kengo Kuma, Anti Object, (Architectural Association London, 2008), 14

${ }^{47}$ Hans Georg Gadamer, Elements of a Theory of Hermeneutic Experience in Truth and Method (Wahrheit und Methode, 1960).

${ }^{48}$ In writing about the work of the Portuguese architect Alvaro Siza, Leatherbarrow contends that a sketch has this attribute and moreover this incompleteness prompts
} 
As explained previously these Sight Lines may be additive or reductive. They may be tracks left by animals as they migrate or forage for food among the ferns, moss, pine needles and light colored granite or dark amphibolite. These lines may also be tracks of a human kind; paths made as one walks carefully to avoid poison ivy or oak, over and around the fallen trees now home to colonies of insects and fungus. Paths made by boot, ski and snowshoe, now in deep snow are able to wander more freely without fear of rash or obstacle. These paths track movement and allow for variation in the approach to the site as well as affecting opportunities for access.

The path of the river can also be seen, felt and heard. The falls can be heard from the site but not seen directly in summer through the dense stands of pines, soft maple and young oaks. There are the lines of the existing timber structure on the site, its walls, foundations and ridge of roof. The distances between the timber cabin and the project site can be measured with the use of string. A method used since ancient times of knotting the string with equal lengths to mark the distance. ${ }^{49} \mathrm{~A}$ site is also marked prior to

creative work. He considers that the "marks of the drawing survey are incomplete indications of a possible project." D. Leatherbarrow (EPA) video.

${ }^{49}$ Paul Emmons cites Leon Battista Alberti as noting that among the ancients "it was customary to mark out the line of the intended wall with a trail of powdered white earth." Drawing Sites: Site Drawings. Paper given at AHRA Conference "Field/Work" in Edinburgh, November 2009. 
construction works with physical lines. Boundaries are made with string or rope to denote geometries where the foundation or the outer limits of construction are to be found..$^{50}$

The site may also be marked with thread, tape, chalk or ink. ${ }^{51}$ These are utilitarian lines that mark to impart information, distance and geometry. Architectural elements that may be used, wood, brick and stone are made with many types of lines, but once removed from the site they too disappear. When traces are left behind, they leave ruins, like the fieldstones that once made up foundations of barns and homesteads in the area, farmland

\footnotetext{
${ }^{50}$ Leon Battista Alberti uses the Latin word "Lineamenta" in his De Re Aedificatoria and dedicates the first book in his treatise to its understanding. The translation and therefore the interpretation of his meaning has been subject of much academic controversy. On construction sites the builder would use tracing lines, ropes, ribbons, strings or threads were made mostly with flax fibers or linen, which do not distort with weather and age. The Latin origin of the word linea (line) is derived from linum meaning linen thread (also made with flax. See Marco Frascari, Eleven Exercises in the Art of Architectural Drawing (Taylor \& Francis, 2011), 99 for historical telling of Alberti's understanding of denoting lines (lineamenta).

${ }^{51}$ Carpentry tools include a chalk line, often blue, where a string under tension is snapped against the work piece or site to create an accurate, thin, straight line between two points. In Japan The Sumitsubo is used by master Japanese carpenters. It is similar in function to the Western chalk line; it is used to mark thin, straight lines on wood and other materials. Instead of chalk on string a fine silk line is drawn out through an ink soaked wad of cotton, tensioned and then snapped. They are both also used as a plumb line. Odate, Toshio. Japanese Woodworking Tools: Their Tradition, Spirit and Use, (1998).
} 
spolia. ${ }^{52}$ Piles of these fieldstones can be seen in farm fields, "gathered for some ghost purpose," or can be stumbled upon in a clearing in the woods. ${ }^{53}$ Even these physical architectural elements now out of use but still in context signify something other than its earlier existence. ${ }^{54}$ It provides an opportunity for a dialogue with previous manifestations. Federica Goffi in her book Time Matter(s): Invention and Re-Imagination in Built Conservation describes the approach the Norwegian Architect Sverre Fehn took in building the museum in Hamar, Norway around existing ruins.

${ }^{52}$ The celebrated Canadian Poet Al Purdy wrote about the counties around Concession 9 Part Lot 5, including Elzevir in his poem The Country North of Belleville. He writes: And where the farms have gone back to forest are only soft outlines shadowy differences -

Old fences drift vaguely among the trees

a pile of moss-covered stones

gathered for some ghost purpose

has lost meaning under the meaningless sky

- they are like cities under water

and the undulating green waves of time are laid on them -

See Appendix B1 for the poem in its entirety. From Beyond Remembering: The Collected Poems of Al Purdy, (Harbour Publishing: 2011).

${ }^{53}$ In southern Ontario fieldstones were collected from fields and streams rather than quarried from bedrock outcrops. This was most common in the mid $19^{\text {th }}$ Century. Bedrock is covered in thick layers of glacial debris left by retreating ice sheets 10,000 years ago. Fieldstones were easier to obtain.

${ }^{54}$ There is something reminiscent of the famous lines from the 1910 essay 'Architecture' by Austrian architect Adolf Loos, "when we stumble upon a mound in the forest, six feet long and three feet wide, formed into a pyramid shape by a shovel, we become serious and something within us says, 'Someone lies buried here'. This is architecture." Loos made the observation that architecture when not in harmony with its context can cause dissonance and for him, unnecessarily "shatters the quiet". Aldolf Loos. Essay in Architecture, 1910. 


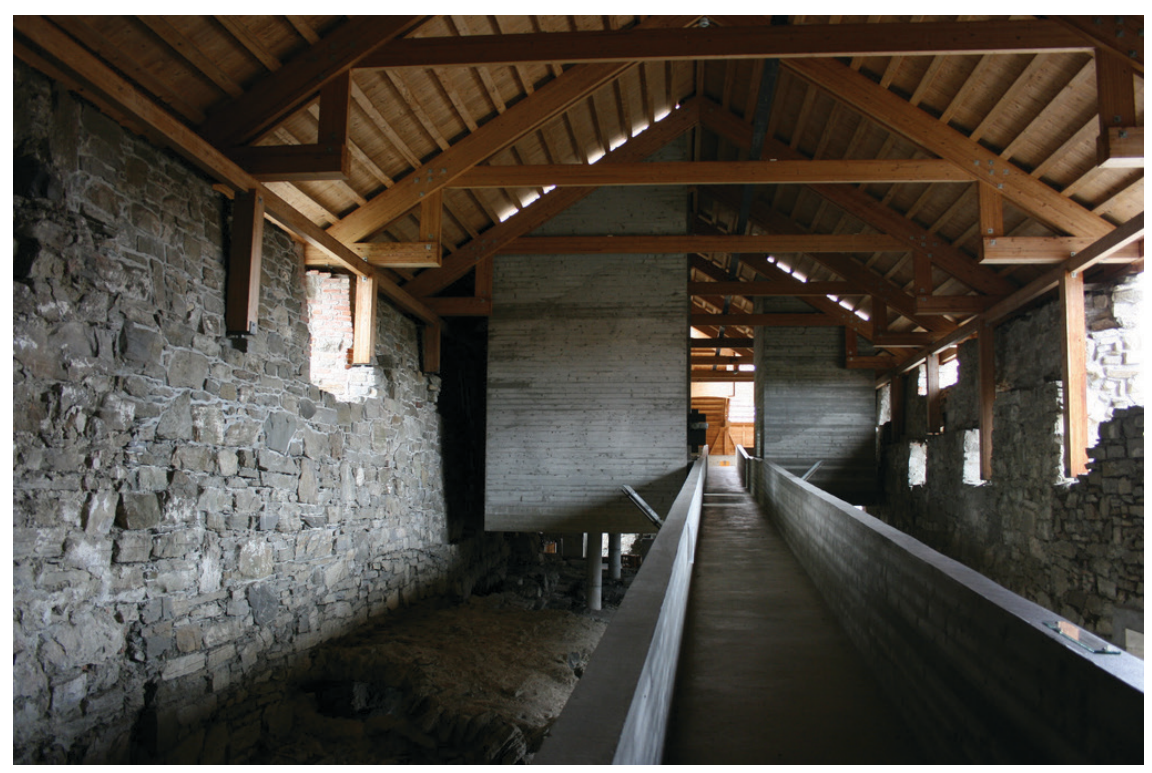

Illustration 10: Sverre Fehn, The Hedmark Museum, Norway, $1973^{55}$

His approach allowed the historical objects, the content of the museum, to "re-inhabit the past meanwhile acknowledging its identity." ${ }^{, 56}$ Furthermore, she adds:

“The objects may be born again and find their 'space' in their new context. So that the object can find this space, the architect must take up residence in the objects, as words take up residence in the soul of an actor. Past and future live close together, meeting at junctures created by openings along the ruin wall, allowing a see through from the new into the old-generating simultaneous existence of a building within a building. Merging past and future through a layering allows a permeability of time reminiscent of Carlo Scarpa's design for

\footnotetext{
${ }^{55}$ Accessed May 2014 from http://elizabethquigley.files.wordpress.com/2011/10/screenshot-2011-10-02-at-3-16-30-pm.png

${ }^{56}$ Federica Goffi, Time Matter[s]: Invention and Re-Imagination in Built Conservation the Unfinished Drawing and Building of St. Peter's, the Vatican, (Surrey: Ashgate Publishing, 2013), 165-166.
} 
the courtyard façade of Castelvecchio in Verona, where the past merges with the future born in the voids of an incomplete image." 57

There is an opportunity then, when objects, architectural elements or otherwise can be integrated and brought together to engage with the land in a time that is not of its own. The architect ingests or inhabits the detail and by so doing creates a new layer for which it can exist.

The line where the river water meets the earth, this rich and fertile line that rises and falls with the seasonal widening girth of the river, swollen with the spring melt, raises concerns and the need to consider the risk of flooding. A biological richness can be found where these two edges meet. One that social theorist Richard Sennett has considered in a cultural context where the health of cities can be measured by the frequency with which edges or strangers meet and differences intersect. ${ }^{58}$ It is not because the boundaries are distinct that they have this rich quality, but because they are blurry, layered and able to overlap..$^{59}$

These are lines that can be experienced on the site. But what of the lines when one is no longer present? Away from the site, on the drawing board, when pen meets paper physical lines, sight lines, are also made. Lines on paper are analogous to ropes on the

\footnotetext{
${ }^{57}$ Ibid. 165.

${ }^{58}$ Richard Sennett, Together: The Rituals, Pleasures and Politics of Cooperation, (London: Yale University Press, 2011).

${ }^{59}$ I am indebted to Ryan Stec for this observation and for others too many to number.
} 
site. Paul Emmons in his work on the dashed line and its unique consequences for architectural notation explains that the scoring of the paper was the mark making of renaissance architects. ${ }^{60}$

At times lines on an architectural drawing more literally marked points of incision. Where the linear edge of a spade cuts the surface of the soil creating a new vertical surface in the process. There is an intersection here where visible and invisible lines overlap or echo each other. There are moments when the representation of something on paper indicates something that does not exist in reality, a moment where the dash is a "physically present indication of an omission or a break in thought." ${ }^{61}$ Emmons continues to explain that dash lines are magical notations that allow one to see the invisible, to represent the in-between and has the ability to stitch together the physical and metaphysical.

Again we may turn to Berger and find references to lines, paths and plots. He provides a useful description of the overlap between the seen and unseen, heard and unheard. "No story", Berger writes, "is like a wheeled vehicle whose contact with the road is

\footnotetext{
${ }^{60}$ Paul Emmons Proceedings: Paradoxes of Progress: Architecture and Education in a Post-utopian Era: 89th Association of Collegiate Schools of Architecture (ACSA). Annual Meeting : March 16-20, Baltimore, Maryland. The architect Sebastiano Serlio (1475 - c.1554) in his treatise, I Sette Libri Dell'Architettura ("Seven Books of Architecture") first described dashed lines (line occulte) as a reference to the "hidden" or "secret" portions of geometric solids. As Emmons explains, the process of making a dashed line, whereby the pen alternates between touching and not touching the surface of the paper, suggests the simultaneous inhabitation of two separate planes: on and off the field of representation.

${ }^{61}$ Ibid 458.
} 
continuous. Stories walk, like animals and men and their steps are not only between

narrated events but between each sentence, sometimes each word, every step is a stride over something not said." ${ }^{62}$

Is a map of considerations more likely to describe and follow stories that walk? Like Ariadne's thread reading the path is not just physical, the path is the story ${ }^{63}$

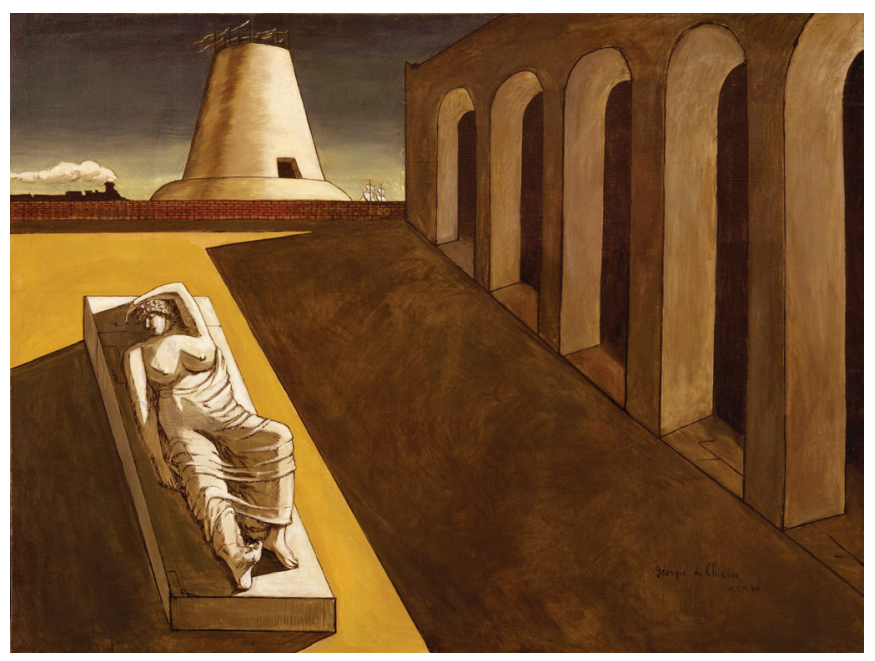

Illustration 11: Giordio de Chirico, Square with Ariadne (1913) The Metropolitan Museum of Art ${ }^{64}$

${ }^{62}$ John Berger with Jean Mohr, Another Way of Telling (New York: Pantheon Books, 1982), 284-285.

${ }^{63}$ Ariadne was the unfortunate daughter of King Minos of Crete chosen by lot to be fed to the Minotaur. She is associated with mazes and labyrinths as she helps Theseus escape the Minotaur with her gift of thread. Italian artist Giorgio de Chirico (1888 - 1978) painted a series of Ariadane asleep on the island of Naxos where in some myths she has been abandoned by Theseus only to be seen by Dionysus who falls in love with her, marries her and makes her immortal. The paintings have no single vanishing point, but instead have many. The iterative paintings are considered to be on the border between representation and abstraction. Michael Taylor, Giorgio De Chirico and the Myth of Ariadne (London: Merrell Publishers Ltd, 2002).

${ }^{64}$ Accessed May 2014 from

http://artobserved.com/artimages/2011/12/gm_322524EX2.jpg 


\subsection{Insight(ful) Lines}

What does it mean to consider a site waiting for architecture? What lines were there once but now no longer; water levels, tree stumps, footprints in soft mud. Lines are joined by lines that may appear some day still to emerge. These lines might also need to be considered and perhaps factured, marked somehow. Lines not drawn like things unsaid. ${ }^{65}$

The architect and educator John Hejduk drew lines all his life. ${ }^{66}$ He proposed that architectural tracings of the site might be apparitions, "xrays of thoughts, meditations on the sense of erasures: to fabricate a construction of time." ${ }^{97}$ In an introduction to Mask of Medusa architect Daniel Libeskind describes Hejduk as a messenger of the invisible and his work as having the ability to un-conceal, "A seeing which by virtue of being concealed yet visible, has access to the experience of an uninvited pausing, a surprised witnessing. " ${ }^{98}$ Hejduk in his work Berlin Night, a hybrid journal with writing, collage and drawings uses the collection of multivalent considerations expressed with mixed media to represent the city as more than a complex source of information. Is it possible to

\footnotetext{
${ }^{65}$ David Summers dedicated a chapter to the term 'facture' in his book Real Spaces: World Art History and the Rise of Western Modernism. (London: Phaidon Press, 2003) to indicate that which has been made in his analysis and proposal for a new art history methodology that include 'world art history.' The term is also used by Marco Frascari "A reflection on paper and its virtues within the material and invisible factures of architecture.” In Marco Frascari, Jonathan Hale, Bradley Starkey, From Models to Drawings: imagination and Representation in Architecture (London: Routledge, 2003). ${ }^{66}$ John Hejduk drawing books include: Berlin Night (1993); Soundings (1993); Architectures in Love (1995); and Mask of Medusa (1995).

${ }^{67}$ Hejduk, Victims (London: Architectural Association, 1986).

${ }^{68}$ Daniel Libeskind Mask of Medusa. (New York: Rizzoli International Publications, 1985). Introduction.
} 
approach the site of Concession 9 Part Lot 5 with a similar consideration of the elements of the landscape and their eidetic and poetic nature $?^{69}$

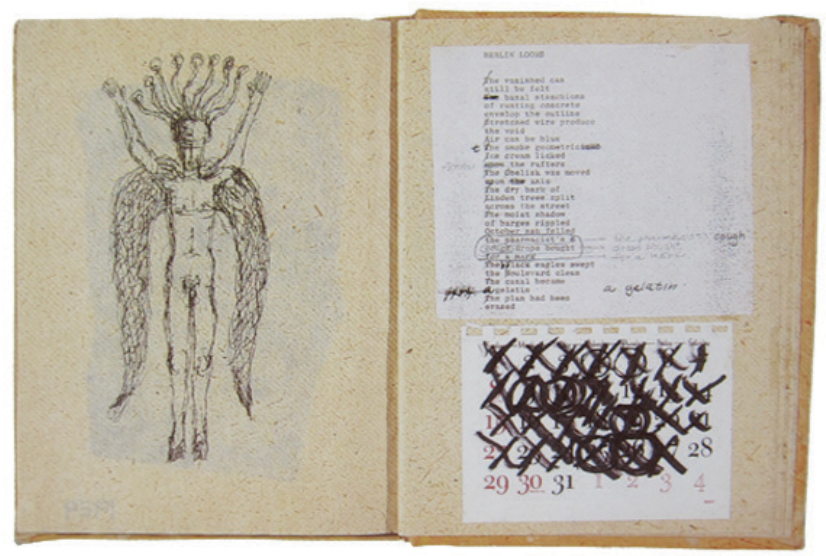

\section{Illustration 12: John Hejduk, Berlin Night, 1993, Canadian Centre for Architecture}

\section{Archives, Accessed May 2014}

What is the sense to be found in erasure? Perhaps first there must be a recognition that every intervention leads to landscape loss. When something is removed from the site, in the course of ground works, preparations made for construction, for example, what trace does it leave? Is it a complete reduction? Similarly when a line is erased from a drawing does the page remember like spaces remember, as rivers may too remember?

In 1953 Robert Rauschenberg created an artwork by erasing a drawing given to him for the purpose by the Dutch American artist Wilem de Kooning. The drawing was mixed media, including oil paint and charcoal. It took Rauschenberg one month to erase. ${ }^{71}$

${ }^{69}$ Ibid. Eidetic is defined as the mental images that have unusual vividness and detail as if actually visible.

${ }^{70}$ Accessed May 2014 from http://2.bp.blogspot.com/-

hfHVSv_36MU/Thw9vdmUvzI/AAAAAAAAA7o/sKoipTm7riY/s1600/notebook+3.jpg 
The result is a field of marks. Complete erasure not being possible as Rauschenberg is aware and has made us aware that something else, in this case, art, was once there.

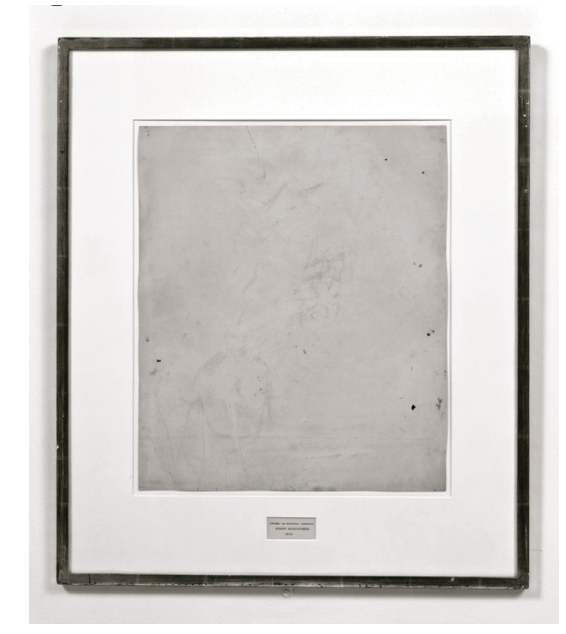

\section{Illustration 13: Robert Rauschenberg, Erased de Kooning Drawing, 1953}

In its place now stands art of a different kind. One that encourages us, the viewer, to think beyond the white of the page and imagine what could have been. Erasures imply former existences. Considering former existences may lead to a beholding of the site that is not a contemplation of loss but rather a notation of what can be remembered.

\footnotetext{
${ }^{71}$ Robert Rauschenberg discusses Erased de Kooning Drawing. http://artforum.com/video/mode=large\&id=19778. Again, I am indebted to Ryan Stec for literally pointing this piece of artwork out to me at the Hirshorn Museum in Washington where it was on loan from the San Francisco Museum of Modern Art.

${ }^{72}$ Accessed May 2014 from http://37.media.tumblr.com/4361e32e76601f57f9157f4d3e618dac/tumblr_mvuav3qP1T1r 9xcmto1_1280.jpg
} 
There are real and imagined partial erasures on Concession 9 Part Lot 5. They may come to the surface of a drawing or be found on the site; both can be mapped and so be made physical again through individual acts of beholding, of consideration.

Perhaps we start with a footprint and the architectural plan. A footprint marks the site upon arrival and with weight it is pressed into the earth. The first encounter with the site, how we meet it physically our feet like footings, our legs like columns. The methods of architectural representation described by the Roman architect Vitruvius as ichnographia emphasizes that there was an earlier notion of plan that is not the current Cartesian idea of a horizontal section, but arguably a weighty foot-print that is impressed into the earth. ${ }^{73}$ While unclear, some believe Vitruvius was describing the full scale marking of the earth on the construction site. ${ }^{74}$

\subsection{Timelines}

The inevitability of weathering serves as a reminder of the process of time and the impermanence of materials including our own flesh. With the wearing of wooden steps

\footnotetext{
73 "Ichnographia est circini regulaeque modice continens usus, e qua capinuntur formarum in solis arearum descriptions." Vitruvius, (I. II. 1). The very different modern idea of the architectural plan as a horizontal section derives from Cartesian rationalism by presuming that the $\mathrm{x}, \mathrm{y}$ and $\mathrm{z}$ axes can be rotated in any direction interchangeably in abstract space. J.N.L. Durand (1760-1834) is associated with introducing this idea of plan into architecture that reflects the influence of descriptive geometry. Jean-Nicolas-Louis Durand, Precis of the Lectures on Architecture, trans. David Britt (Santa Monica: Getty, 2000) p. 188. Alberto Pérez-Gómez, Architecture and the Crisis of Modern Science (Cambridge: MIT Press, 1983).

${ }^{74}$ Vitruvius (I II.) See also Hanno-Walter Kruft, History of Architectural Theory, (New York: Zwemmer; Princeton Architectural Press, 1994) 67.
} 
by many feet or the blooms of lichen across a mound of stones we are made aware of the long arc of time experienced on the site. ${ }^{75}$

There is much variation in the permanence of the materials. Weathering of the natural elements, wood and stone in particular, are dependent on the species and mineral configuration. There is only an approximate understanding of how the materials will react, become flawed, altered over time. The existing timber frame building already shows signs of time as the timbers pass into shades of grey and silver as the wood dries and is impregnated with dirt. This is an intentional or expected disfiguration, one that was foreseen by the builder architect. Necessary precautions were made to restrict direct exposure to rainwater with details such as sills, copings and eaves, however, there was an understanding that these will forever need to be maintained if the structure was to remain.

It is this potential to anticipate changes caused by weathering and the juxtaposition of materials that can lead to an awareness of timelines on a site and on any building constructed there. Mohsen Mostafavi and David Leatherbarrow ask:

"What is the value of this accumulated dirt, or this erosion of a finished edge? Is it not tragic? Alternatively does it not show the rightful claim nature has on all works of art? Is not this return of matter to its source, as a coherent body, already

\footnotetext{
${ }^{75}$ Mohsen Mostafavi and David Leatherbarrow. On Weathering: The Life of Buildings in Time (Cambridge: MIT, 1993) considers the physical and technical nature of architectural projects, their temporality and the philosophical and ethical implications of weathering.
} 
implied in its constitution, insofar as every physical thing carries within its deepest layers a tendency toward its own destruction - death as a birthright? If tragic, this metamorphosis is just. The value, then, of works that suffer stains and abrasions is the revelation of the eventuality of this final justice." 76

The passage of time, timelines, can be mapped in some way from a building's inception, construction and inhabitation. Mostafavi and Leatherbarrow propose that as the project moves through these phases the introduction and consideration of the time of weathering:

\begin{abstract}
"brings the project closer to a condition of actuality based on its potential transformations through time. This condition of actuality and potential for staining and fault complements the ideality of the project, making it both independent of the passage of time and caught up within it. Thought of in this way, weathering brings the virtual future of a building into dialogue with its actual present, as both are entangled in its past." 77
\end{abstract}

It is for us to consider then, how to mark the temporal structure of a building? Could one consider the deconstruction or dismantling of the building in tandem with thoughts of its construction? Could the recognition of time passing be made if elements were chosen to remain after others had returned to the land? Thoughts of disintegration and natural

\footnotetext{
${ }^{76}$ Ibid, 69.

${ }^{77}$ Ibid, 112.
} 
wearing could then influence material choices and their sources, the scale of the project, details to enhance preservation or conversely allow for anticipated failure or ageing.

Timelines continue to inform the project as site visits come into consideration. How do site visits inform our considerate mapping? And so we pass from fiction to fiction, from picture to picture and map to map to the lines most salient to the interests that bring us to the site. 


\section{Chapter: The Act of Making a Line}

\subsection{Site Visits}

What does it mean to enter the site to consider the land? Once lines have been identified and have been engaged to express, inform and describe how then are we moved to design? Each visit I asked and mapped in drawings, in photographs and in words: what did I bring? What did I take away? And recorded the changes. Some included paths over snow in April and through brush in June, water levels and topography, the orientation of sun and wind, views including those upward into the trees, the geometry of the existing buildings and proximity to the road. Then I marked in my own way the geometry of my stories in that moment and then later when they had become imperfect memories. These drawings are my considered site visit drawings. They are both simulated memories of the site and a tool for remembering. The drawings are a substitute, a mimetic device as an imitation of an experience on site.

What does it mean to be away from the site? The drawings then become a process by which sensorial information is stored in narrative. It becomes a confabulation, manifestations of errors in what we remember and what we see. ${ }^{78}$ Being away from the site makes its representation more significant.

\footnotetext{
${ }^{78}$ My first encounter with this term in an architectural context was in the book Eleven Exercises in the Art of Architectural Drawing: Slow Food for the Architect's Imagination by Marco Frascari (Taylor \& Francis, 2011), which details the critical nature and role of architectural drawings.
} 
Harvard university professor of Aesthetics Elaine Scarry in her book On Beauty and Being Just explains that when we are confronted with something beautiful it fills the mind yet invites the search for something beyond itself, something larger or something of the same scale with which it needs to be brought into relation. ${ }^{79}$ Simultaneously our minds are prompted to move "chronologically back in search for precedents and parallels, to move forward into new acts of creation". ${ }^{80}$ Beauty then, incites deliberation, a consideration, when it searches for precedents. Beautiful things she writes, "always carry greetings from other worlds within them." 81

Scarry also describes the suspended state of beholding, the cognitive act of the perceiver, as one of three methods by which beauty may actually press us toward justice. By being in the presence of beauty and the perception of that beauty, she argues we are invited to act with ethical fairness. Scarry uses the image of the scale as a metaphor, whereby fairness is held in the balance. The architectural translation then is symmetry. In working and designing how might the building, tectonically, embody these ideas? How then can I engage with the site, the land, as its equal?

The following section is in the form of an internal dialogue between my single voice and the chorus of imagined voices of the land. The voice of the Land, here, is a chorus in the performative spirit found in the plays of classical Greece. Imagine then that the

${ }^{80}$ E Scarry, On Beauty and Being Just, (Princeton University Press, 1999), 32.

${ }^{81}$ Ibid 47. 
collective voice of the Land can be performed with many voices, singing, dancing, with a rhythmic speech, as a theatrical foil, or literary trope that may provide sympathy, or empathy, a character that has its share of the action in both our tragedies and comedies. This is a device to again, add layers of considerations in order to understand the site on which to build and the lines with which to denote the building.

There are three dialogues. Each concerned with different conceptions of time, elements of the architectural project and the process of consideration. The first dialogue is a conversation that includes issues regarding the recording and measuring of the land and explores the layering of time through episodic site visits and questions: 'do you have time?'

The second dialogue is a conversation that presents the materiality of the project to the Land. The conversation includes questions of how the building meets the land and consequently asks 'can you give time'? Key elements of the architectural project are disclosed including: orientation, materiality, construction, and experiential and programmatic details. 
The third dialogue concerns itself with a bargain. It engages the definition of 'a consideration' that means a payment, or exchange in contractual law. A proposal is made to the Land, a bargain, which may or not be accepted. ${ }^{82}$

\subsection{Dialogue 1: Approaching the Land}

J: $\quad$ I had an idea. I wondered if you would have time, or perhaps the inclination to talk with me about it.

The Land: I have time.

J: $\quad$ I have been here before. Many times, (does that matter?) I have swum in this river, with its surface like constellations, I have walked between these trees, been laid down in the pine needles...

The Land: yes, I know...

J: $\quad$ I mean, that I am sometimes here, even when I am not.

${ }^{82}$ In an article titled "Bargains with the Land" Robert Fyfe writes about the work of Carl Schaefer and the art of landscape painting. He proposes that the real subject of all important landscape paintings - what makes them more than just a recording of a picturesque view - is the bargain struck between the landscape and the values of the particular community explicit or implicit in the painting. The bargain is made manifest in the geometry imposed on the landscape and revealed in the painting. The New Brick Reader, ed. Tara Quinn (Anansi: Toronto, 2013), 19. 
The Land: What does it feel like? To be away...

J: $\quad$ I feel I need to bring you with me somehow. To remember... me, here.

The Land: How do you remember? How do you remember each time?

J: $\quad$ I suppose I record them. I write you down... I write me down. I make stories with pictures and words. I document. I measure. Because of the undergrowth in spring, summer, autumn and the snow in winter I can't use a measuring tape, string is of little use. Even if I were to drive down stakes, which I have not yet done, measuring low to the ground gives me a limited understanding of how you rise and fall. So I have tied string, at the height of my daughters' eyes, between the trees to see what those geometries tell me. I record them in drawings, photographs and my memory.

The Land: Sounds imprecise.

J: $\quad$ Perhaps. It is not my intention to be perfectly accurate...I was reminded of a very short story by Jorge Luis Borges. He writes of a land in which the science of cartography is so exact that only a map on a 1:1 scale will suffice to capture the detail, 
the exact physical characteristics of the fictional land itself. But it becomes useless, unwieldy, and they resort to using the land itself and abandon the mapping. ${ }^{83}$

I did measurements of a kind. I used a fallen log, to note distance where it was mostly

level. But there were some details I was interested to know - where the trees were exactly and where the Canadian Shield revealed itself in mounds, I found I marked those very carefully in relation to each other and the directions of North, South, East and West. They became my landmarks. The particular trees, the particular rocks on the site.

The Land: And from which direction did you arrive?

J: $\quad$ I came from the East. Moving fast in a car. We were distracted, my friend and I, busy with ideas and a need to communicate. We arrived to find you under all this snow. I told him stories about you. And me and you. And I started to realize how we are all wrapped up together. Where we sat I knew it was free from flooding, I knew in the clearing we were sheltered from most winds on all sides, I knew under us was bedrock. I oriented myself using the rock that is split on one side with its perfect missing piece still there as if waiting to be put back together. I realized that you, the site, orient me.

${ }^{83}$ Jorge Luis Borges, "On Rigor in Science". The story is not unlike a detail in Lewis Carroll's Sylvie and Bruno Concluded that contained a fictional map that had "the scale of a mile to the mile". When one of the characters notes some practical difficulties with this map he states that "we now use the country itself, as its own map, and I assure you it does nearly as well". Lewis Carroll's Sylvie and Bruno Concluded (London: Macmillan, 1889). 
The Land: I I am always just beneath the surface. If you look... when your lines become landmarks, once they are committed, do these lines change? Do the value of the lines change? Do you stop using your memory?

J: $\quad$ I think they do change... They become more valuable, I can take them with me to where I work, away from here, to a different site - my work site. I don't think I could stop using my memory - it's too vivid, it's too present.

The Land: $\quad$ That may change... but you are here now, thinking about me and you...our paths have crossed with Kairos, the unpredictable time of chance, and of opportunity... Do you always anticipate a return ${ }^{84}$ ?

J: $\quad$ Yes, both real and imagined returning.

The Land: What did you bring with you?

\footnotetext{
${ }^{84}$ The architectural theorist and educator Marco Frascari writes in his Eleven Exercises in the Art of Architectural Drawing (Taylor \& Francis, 2011), 69, that for the ancient Greeks there were two kinds of time: Chronos and Kairos. "Chronos, straightforward chronological, historical time, measured with timepieces and calendars; and Kairos, the less tangible, mercurial, unpredictable time of chance, of opportunity..." He continues: "Astounding drawings materialize when these two aspects of time cross or merge since drawing is based on the right timing...Both types of time are resources for the architect...Patience in drawing, often overlooked as a resource, is more than the willingness to wait: it is also the willingness to facilitate rather than to dominate and to know when it is that the opportune moment presents itself."
} 
J: $\quad$ I brought my camera, my pen, my little book of blank pages, my body and all its senses, and nonsenses... I brought my friend. I brought a witness with whom I could talk and share.

The Land: What did you take?

J: I took photographs. I took notes. I took new memories. I took my time. ${ }^{85}$

\subsection{Dialogue 2: The building meets the Land}

J: I have a project I have been working on. I'd like to work it out loud with you if I could. Can you give (it) time?

The Land: I have time.

J: $\quad$ I have been making lines, marking paper and trace. The lines have become architectural - they offer descriptions of materials and programme. They detail elements of construction, how one material meets another, how and where light and shadow fall and how the sound of the rain can be heard and where it can be collected...

${ }^{85}$ See Illustration 14 Dialogue 1 Site Visit Collage: Mixed Media, p. 45a. 
The Land: So where do you begin?

J: On the existing stone. ${ }^{86}$ To touch the earth lightly, there are three exposed mounds of bedrock on the site. ${ }^{87}$ By using those as foundation I can cantilever the building, raising it up off the ground.

J: Can you take the weight?

The Land: $\quad$ Not alone.

J: $\quad$ I can support the roof and walls with wood columns set with a pin and strapping in a small footprint of concrete. Like a foot caught in riverbank mud... and my strings wrapped around slender tree trunks...The columns will need to make up for the lack of a fourth mound of stone to rest the building on. There is the split rock to orient the building to the north, the path that leads from the south up the ridge to the pond

\footnotetext{
${ }^{86}$ In the section on the "Characteristics of the Materials of Foundation-Beds" Solid Rock is given these attributes: "Solid Rock, or as it is locally know, BED-ROCK, or LEDGE, is proverbially a solid foundation. The harder rocks, such as granite, trap, slate, sandstone, limestone, etc., are all capable of carrying the load of any ordinary structure." The Architects' and Builders' Hand-Book (John Wiley \& sons, Inc. New York 1921), 135.

${ }^{87}$ The notion of "touching the earth lightly" is attributed to the Australian Aborigines and has influenced the work of the architect Glenn Murcutt. The Architectural Record notes his design adherence to this principle: "Murcutt often floats his buildings a few feet from the ground on posts, to protect against storm water and insects and maximize ventilation. He favors narrow linear plans, oriented East-West, to amplify summer breezes and winter sun, and wraps his houses in movable louvers, screens and glass doors, making them comfortable in all seasons, without air-conditioning." Architectural Record, May 2009. Vol. 197, No. 5.
} 
beyond, there is the crest of stone that runs east-west that makes a clear line of sight to where the woods start again as the soil becomes deep enough to grow more trees. All these elements must be given their moment. They must be preserved. ${ }^{88}$

The Land: I know where my elements are, where will yours be from? What kind of importation can be expected... how far do things need to travel to become a part of me?

J: $\quad$ The wood can be of this wood, milled up the road, as I know it to have been done before. A mix of woods as you are a mix of woods... maple, pine, larch...The concrete can be made here on site in small batches, the components carried in on our backs. The screws and bolts will likely be from China, but will allow for reclaiming and reusing perhaps one day... The glazing, Germany...I will think about this more...

The Land: $\quad$ And who am I to expect here? And what will they be like here, what could they feel, experience...in their time here?

J: I have been thinking about this... I am still thinking about this... Is it possible to create somewhere to retreat to or do we retreat from...how to keep the space open to gather, eat, drink perhaps celebrate, and be both intimate and welcoming? I have

\footnotetext{
${ }^{88}$ See Illustration 15 Details of Land with Sketches - Mixed Media, p. 47a and 47b.
} 
been thinking about the Thanksgiving table... how every year it expands and contracts depending on the number of people expected and how there is room always made for some unannounced arrival. The movement through the interior spaces becomes important, like making paths through the woods, made to move differently because of the uneven and subtle changes in levels. My pencil tracing turns to choreographic notation and will give direction to the movement of people through space.

The Land: Like dancing...perhaps draw lines for the erratic and spontaneous movement of your children.

J: $\quad$ Yes, children and dancers and bodies at rest, and bodies not like my own...

J: $\quad$ There are other key details I have drawn. The threshold, the passage from inside to outside has been drawn many times. The words of Gaston Bachelard have settled in me while drawing:

How concrete everything becomes in the world of the spirit when an object, a mere door, can give images of hesitation, temptation, desire, security, welcome and respect. If one were to govern an account of all the doors one has closed and 
opened, of all the doors one would like to re-open, one would have to tell the story of one's entire life. ${ }^{89}$

There are the doorways in and out and through but there are also windows. They will be frames with which to see the movement visible in the woods, snow, rain, and leaf fall, slow moving shadows made by moon and sun. Frames to capture both movement and stillness. ${ }^{90}$ I would like to know how close I could get to you without touching.

The Land: $\quad$ How will you keep me out, provided you think you will want that at times... or perhaps how do I keep you in?

J: $\quad$ The roof will be another place that we meet. There are places that will open to the sky and open to the earth. Not all at once, a gradual beholding if you like...

The Land: What did you bring with you this time?

${ }^{89}$ Gaston Bachelard, The Poetics of Space, (Boston: Beacon Press, 1994), 224. In the chapter titled "The Dialectics of Outside and Inside" he warns of a division when contemplating inside/outside and therefore the possibility of a positive and negative association, of being and not being. The design has been influenced instead by his call to daydream: "But how many daydreams we should have to analyze under the simple heading of Doors! For the door is an entire cosmos of the Half-open." 222.

${ }^{90}$ In the Buddhist tradition there is an awareness of the fundamental condition of existence that is not a cause for nihilistic despair, but rather a call to vital activity in the present and a gratitude for another moment being granted to us. These elements are in the art of Sansui in which the reality of constant change and impermanence is honored in Japanese dry landscape gardens. Francois Berthier, trans. Graham Parkes Reading Zen in the Rocks: The Japanese Dry Landscape Garden, (London: University of Chicago Press, 2000). William Theodore de Bary, Sources of Japanese Tradition, Vol. 1, (New York: Columbia University Press, 2001). 
J: $\quad$ I brought string and thread. I laced my way through trees and paths. Like the roaming refugees of the imagined Ersilia I made relationships. ${ }^{91}$

The Land: What did you take with you this time?

J: $\quad$ I took photographs. I took details. I took moments. ${ }^{92}$

\subsection{Dialogue 3: Presenting the bargain to the Land}

J: $\quad$ I wonder now, with more talking (of course, continuous talking) if I may make a proposal. See if we can come to some kind of agreement, a bargain. Do you have time to consider?

The Land: I have time.

${ }^{91}$ Italo Calvino, Invisible Cities, trans. William Weaver (London: Harcourt, Inc.), 62 "In Ersilia, to establish the relationships that sustain the city's life, the inhabitants stretch strings from the corners of the houses, white or black or gray or black-and-white according to whether they mark a relationship of blood, of trade, authority, agency. When the strings become so numerous that you can no longer pass among them, the inhabitants leave: the houses are dismantled; only the strings and their supports remain." See Appendix B2 for text in its entirety.

${ }^{92}$ See Illustration 16 Dialogue 2 Site Visit Approach Photographs, p 50a and Illustration 17 Dialogue 3 Site Visit String Series: Photographs, p. 50b and 50c. The hand written text in the second to last photograph in the series belongs to Ryan Stec - open questions and questioning of architecture. 
J: $\quad$ I would like to build here, for anyone who cares to visit, a space to be in the landscape alone or with others. I want to eat here, sleep here, be warm and cool here...I want to build a place to share stories.

The Land: How long will it last? In what time?

J: $\quad$ I had thought that as I will not endure perhaps over time choices will be made to only keep some elements. Perhaps a threshold will remain enclosed, like a hanging door half open. Or the path, the path to the building will age and weather but will remain somehow. An effacement rather than erasure...

The Land: This is my note of caution to you. Take care not to mythologize me. Do not treat me with such reverence that I remain unchanged, unmoved by your ideas, your lines made real into built form. You may need to reframe the physical landscape in each and every project, and you can as long as you remember. ${ }^{93}$ What is your way of remembering? You may add and subtract, make imaginary or real changes, but your

\footnotetext{
${ }^{93}$ That nature should never be regarded in a romantic way - architecture must create a tension between nature and an architectural intervention are thoughts attributed to Sverre Fehn's design philosophy as noted by the Pritzker Prize jurist Ada Louise Huxtable in an 1997 essay titled "The Paradox of Sverre Fehn.” www.pritzkerprize.com/1997/essay, accessed May 2014.

Jill Stoner in Toward a Minor Architecture (MA: MIT Press, 2012) writes in particular about the urban environment and advocates a metaphysical reading of the landscape - to re-territorialize nature in order to construct space rather than occupy it requires a kind of demystifying of nature.
} 
motivation should not be to detract. ${ }^{94}$ You must enhance what is here, at this time. For you to become more permanent, you must endure. ${ }^{95}$ You must endure well. That is a bargain we must be willing to make.

J: $\quad$ How much can I take?

The Land: You can take whatever you want as long as you give it back.

The Land: What did you bring?

J: $\quad$ My drawings and my considered mappings. I made changes. I amended my memories. I reoriented.

The Land: What did you take?

J: $\quad$ Drawings and photographs. A palimpsest with impressions of collaged moments in which this building can be found. ${ }^{96}$

${ }^{94}$ Leon Battista Alberti, Ten Books on Architecture (1452). The architect when confronted with a building will immediately become engaged with adding and subtracting elements to always improve on what exists but must never detract.

${ }^{95}$ Marc-Antoine Laugier, Essai Sur L'Architecture, Ed. 1753, (Paris: Hachette-Livre BNF, 2012) describes the primitive hut, the human need for permanence in accordance with nature and the origins of the column. See also Joseph Rykwert, On Adam's House in Paradise: The Idea of the Primitive Hut in Architectural History (1972).

${ }^{96}$ See Illustration 18 Dialogue 3 Site Visit Collage: Photographs, p. 52a. 


\subsection{The Imagined Project}

The project proposal for Concession 9 Part Lot 5 is a modest sized building to gather in comfort in the landscape. The materials are largely wood of various species, with glazing and minimal concrete for foundational support. There are visual openings through the roof and the floor to reveal and remind. There is a small wood-burning stove, with seating areas and windows to frame the Land's many characters.

Interior pathways are designed to facilitate further movement through the building, as if it wasn't there, as well as to invite pause and recognize that which has been captured for the time being. Inside you are meant to forget you are housed. Outside you are meant to see there is a house. There is a simplicity in the language, an efficiency in its functioning and a self sufficiency in its intentions.

The roofline is an echo of those found on concession lines across the province with the exception of the doubling of the peaks and their inner slopes glazed. These lead to a trough, a gutter that runs the line of the building and comes out in spouts to the East and West. This will allow for rain and thaw to be witnessed as it falls past the windows and onto the moss, earth and stone below. A chain hangs to turn frozen water into sculpture. 


\subsection{Lines of Beginning}

Concession 9 Part Lot 5 is a site made of lines. Storylines, lines unseen, lines found and made tangible, lines made with the body, lines made by the earth, the elements, age and weathering, lines made in the past, in this present and in its imagined future. When the interrelationships, the layers, are read these lines become a consideration for design. The architect must determine to mind or ignore the lines at the time of drawing. The time of drawing out the building that can be imagined to rest on that piece of land in Elzevir County by the Skootamatta River.

'Maps of consideration' are made of these layers of lines and will run through the evolution of drawings that follow. Throughout the considered process there is a dialogue with the site. This dialogue contains an agreement, tacit or if desired, explicit and dialectic. The project and its resultant geometry imposed on the land is a manifestation of the bargain.

This project and its fictions are a way to remember. Remember the contract, the details, the moments that have made an impression so that each one that finds its way onto trace is a marking that belongs to an iterative process of making considered lines. 


\section{Appendices}

Appendix A : Imagined Project Drawings

\section{A.1 Sketch Drawings on Trace Paper}

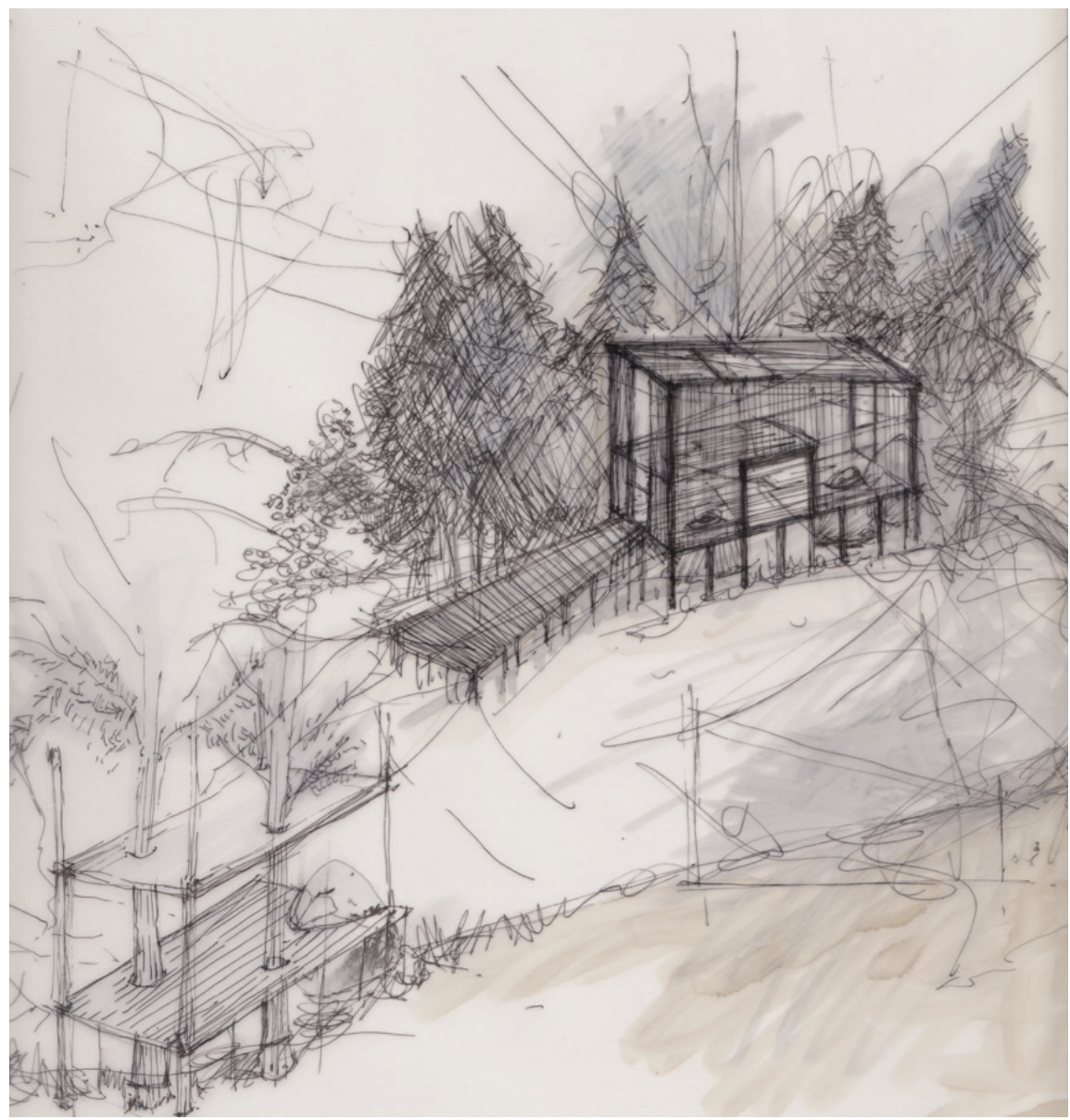



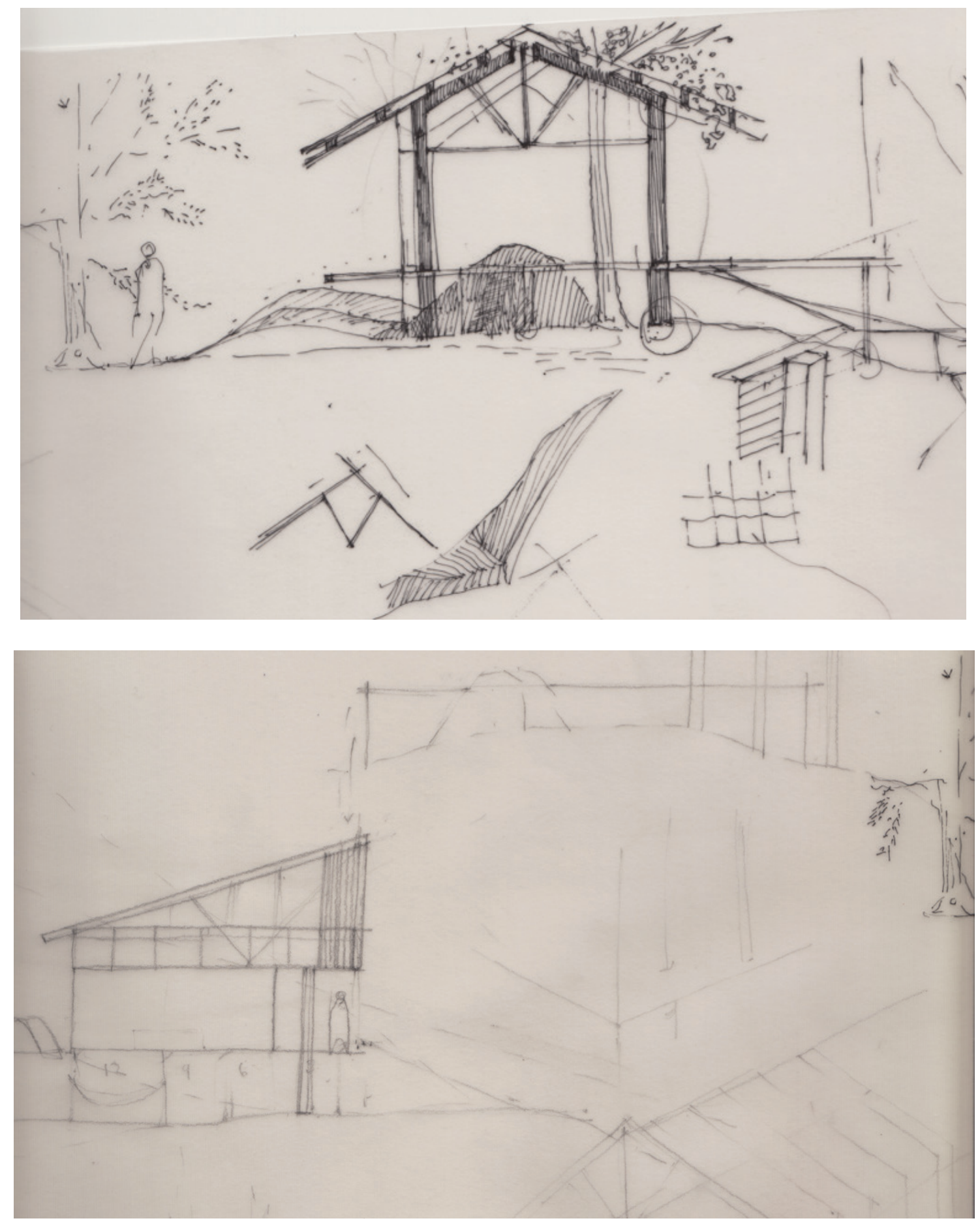

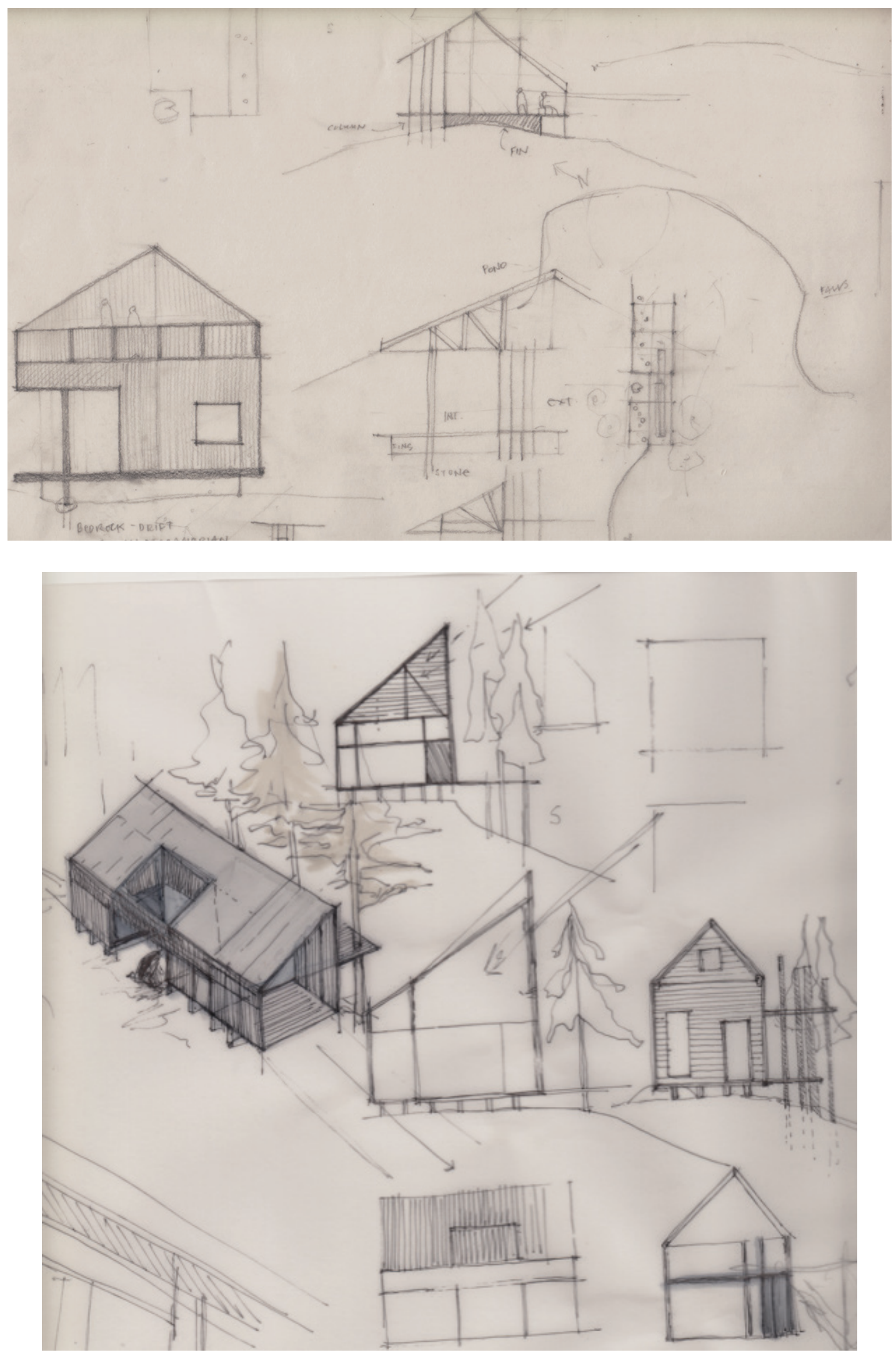


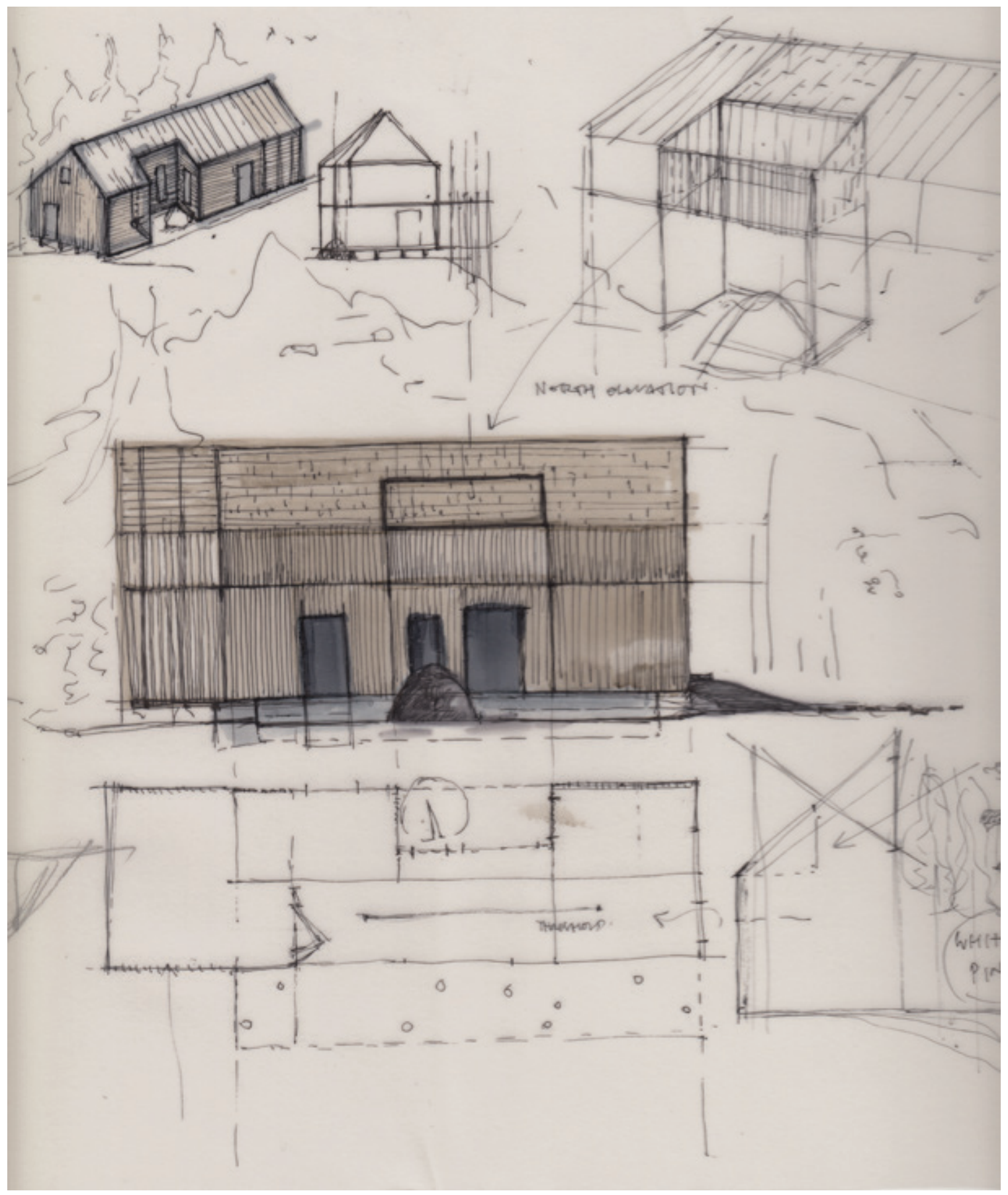




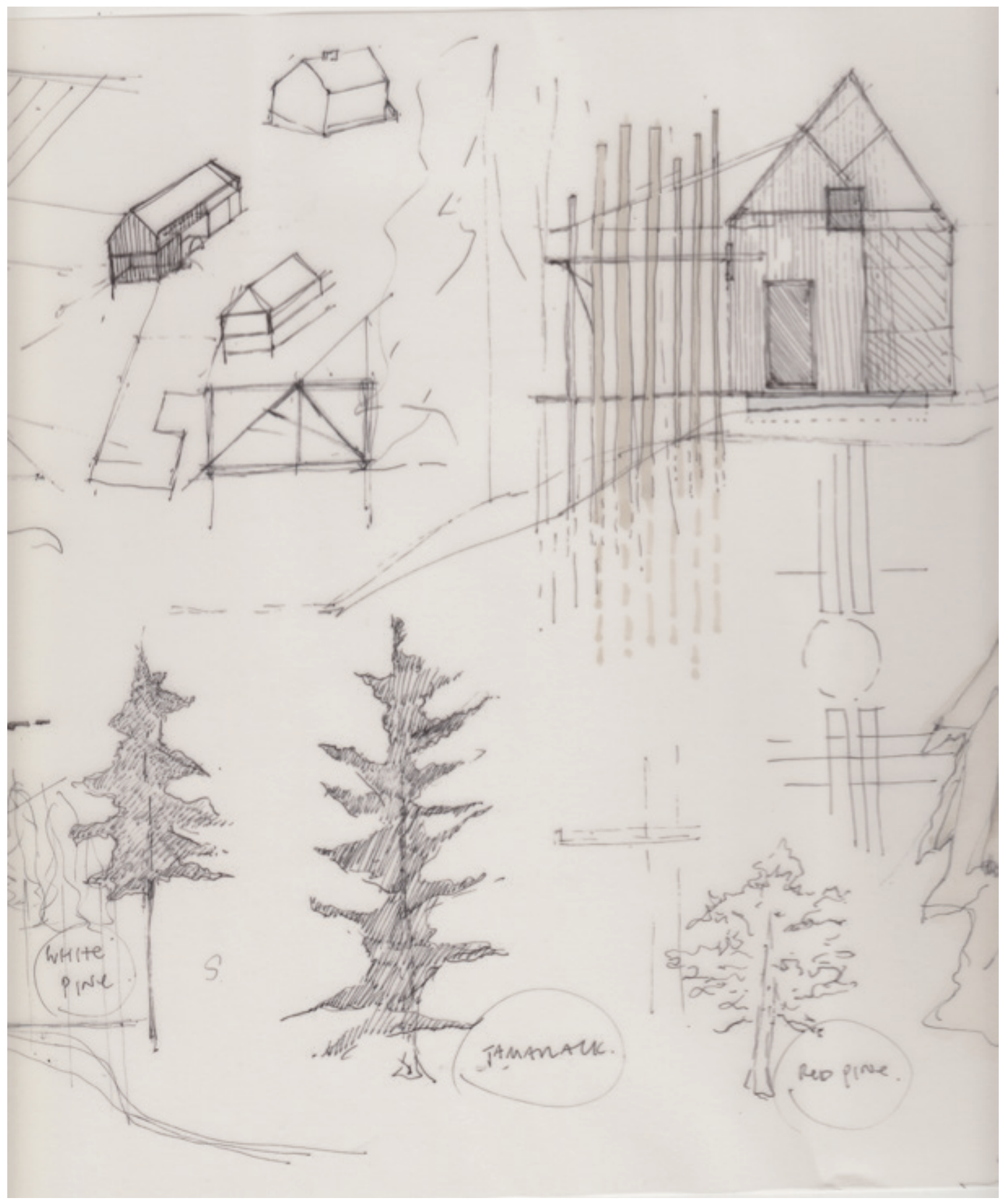




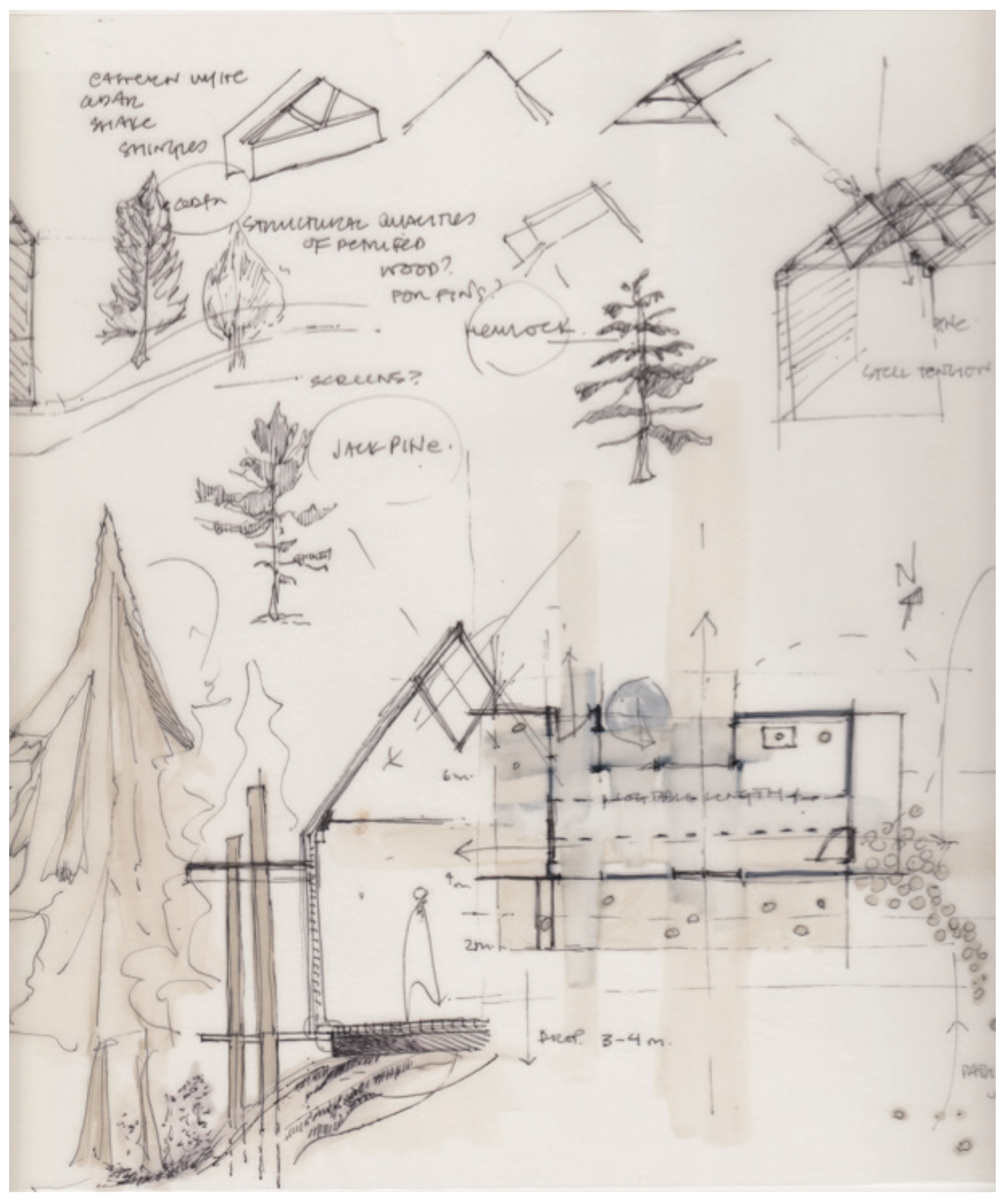



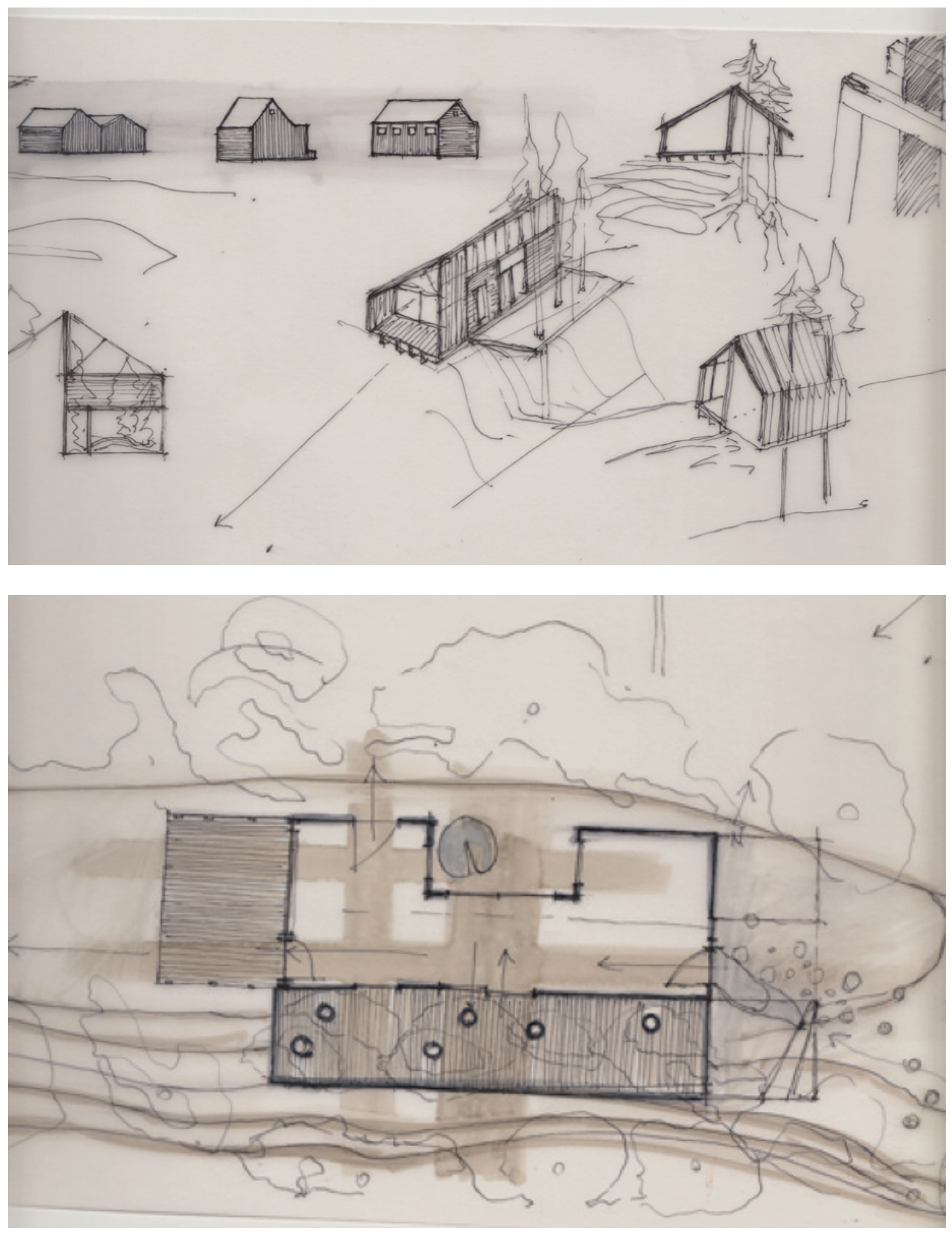

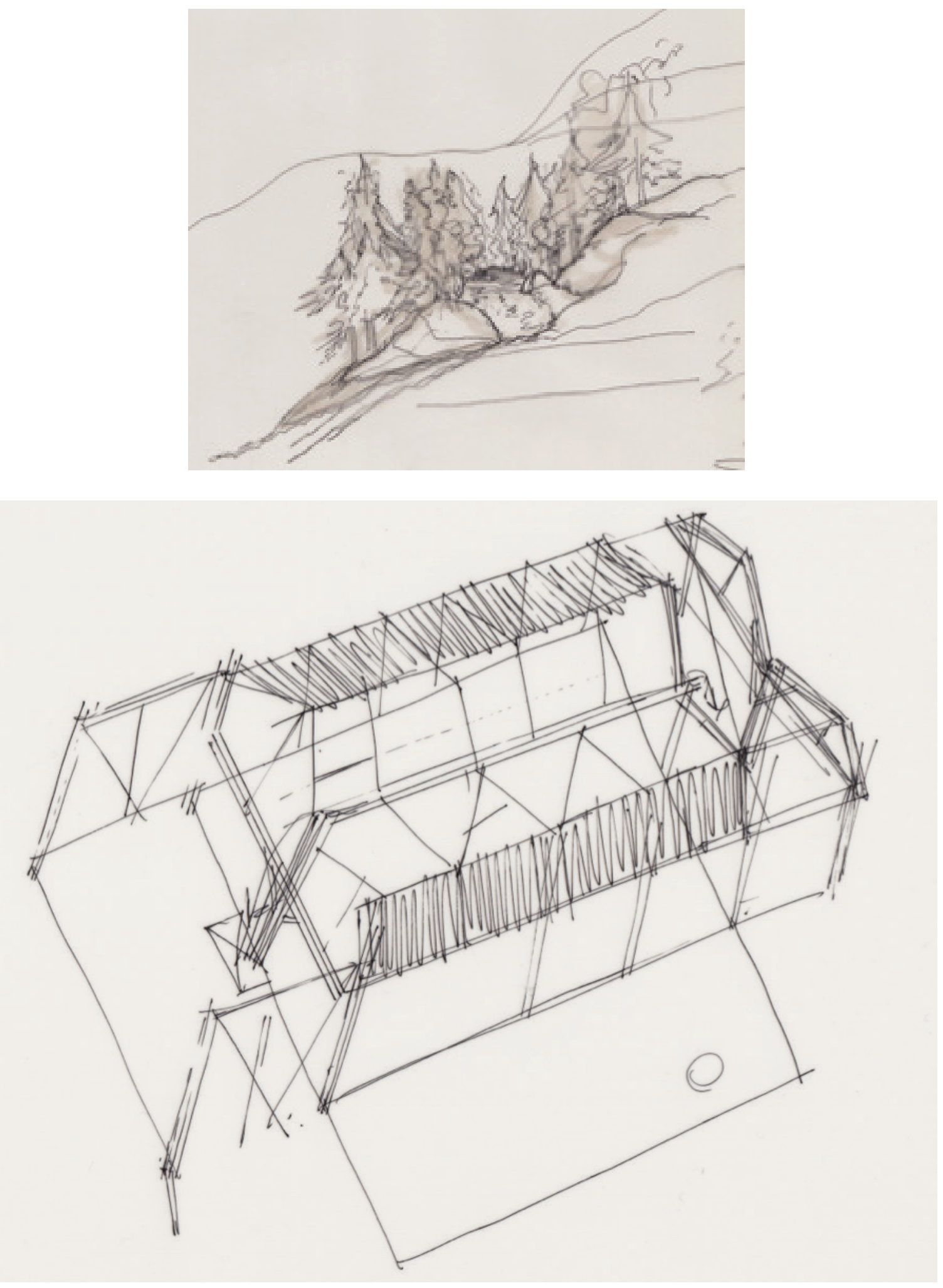

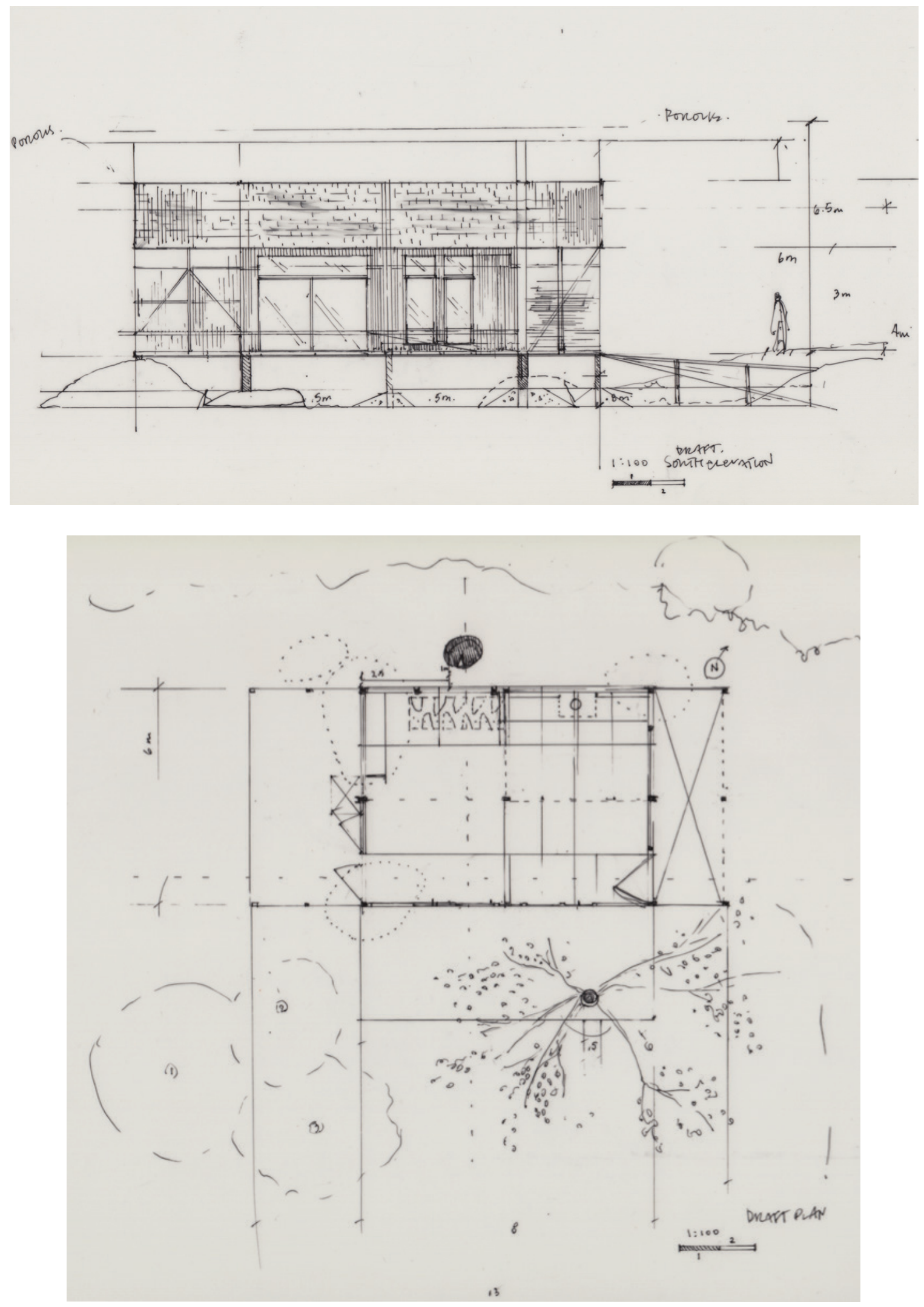


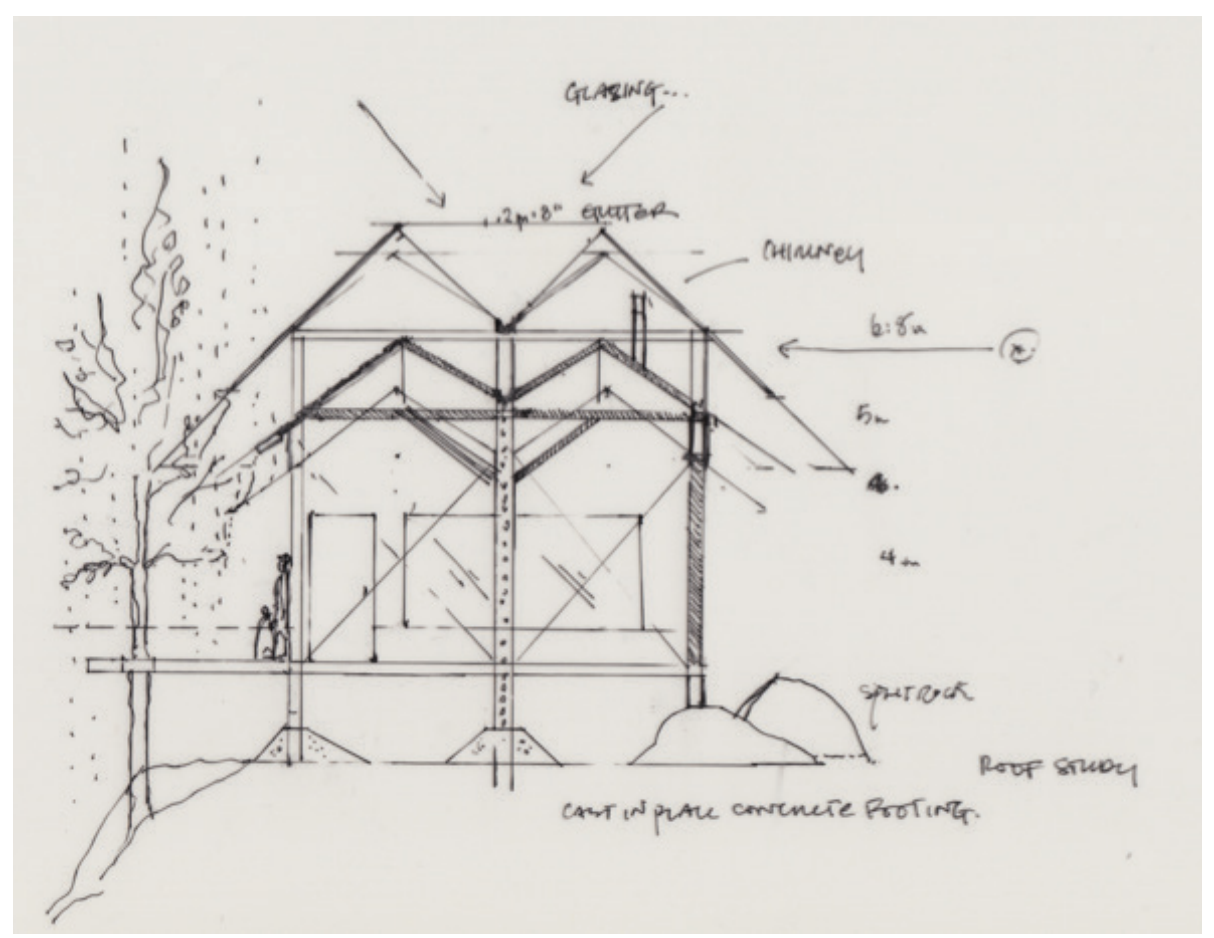



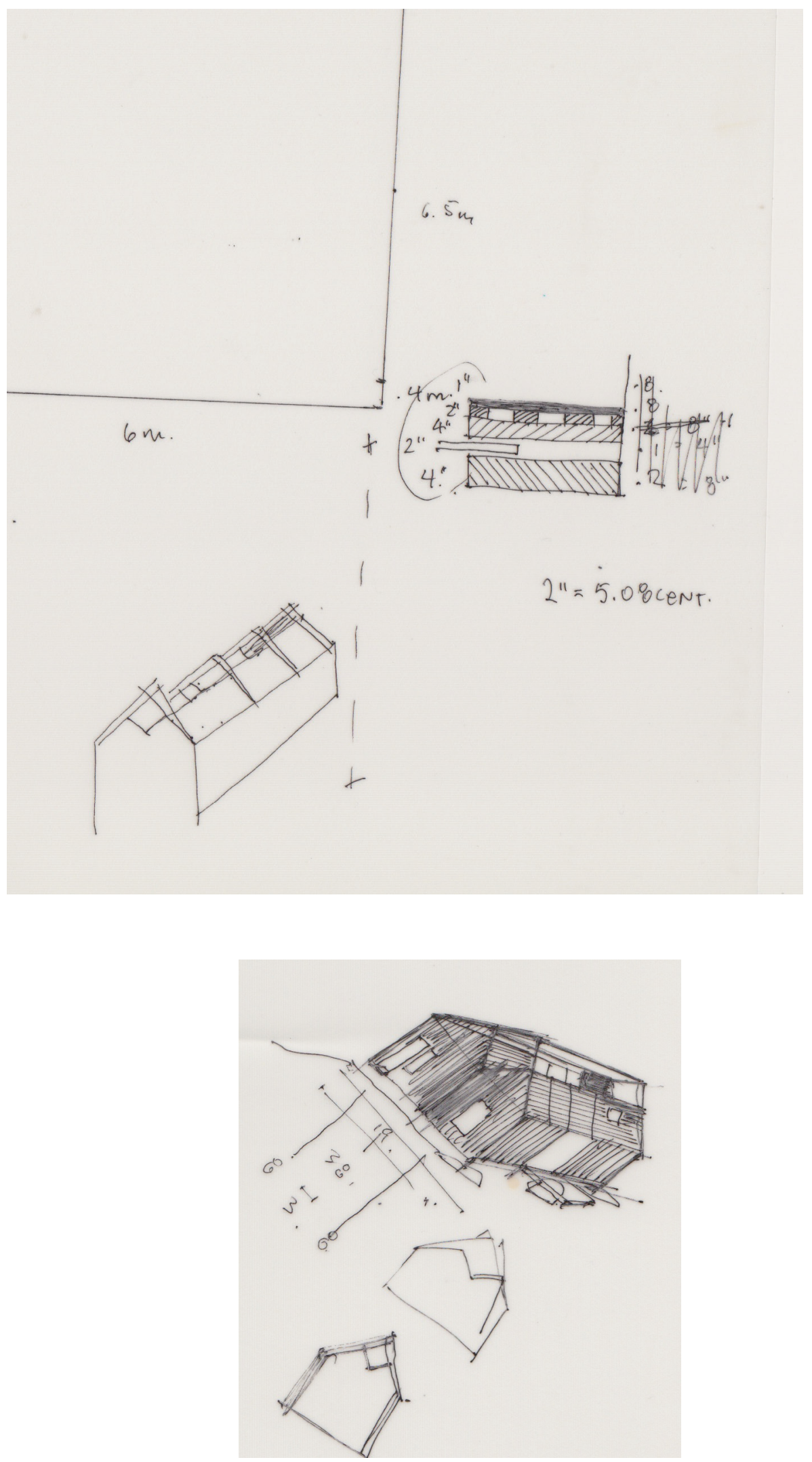


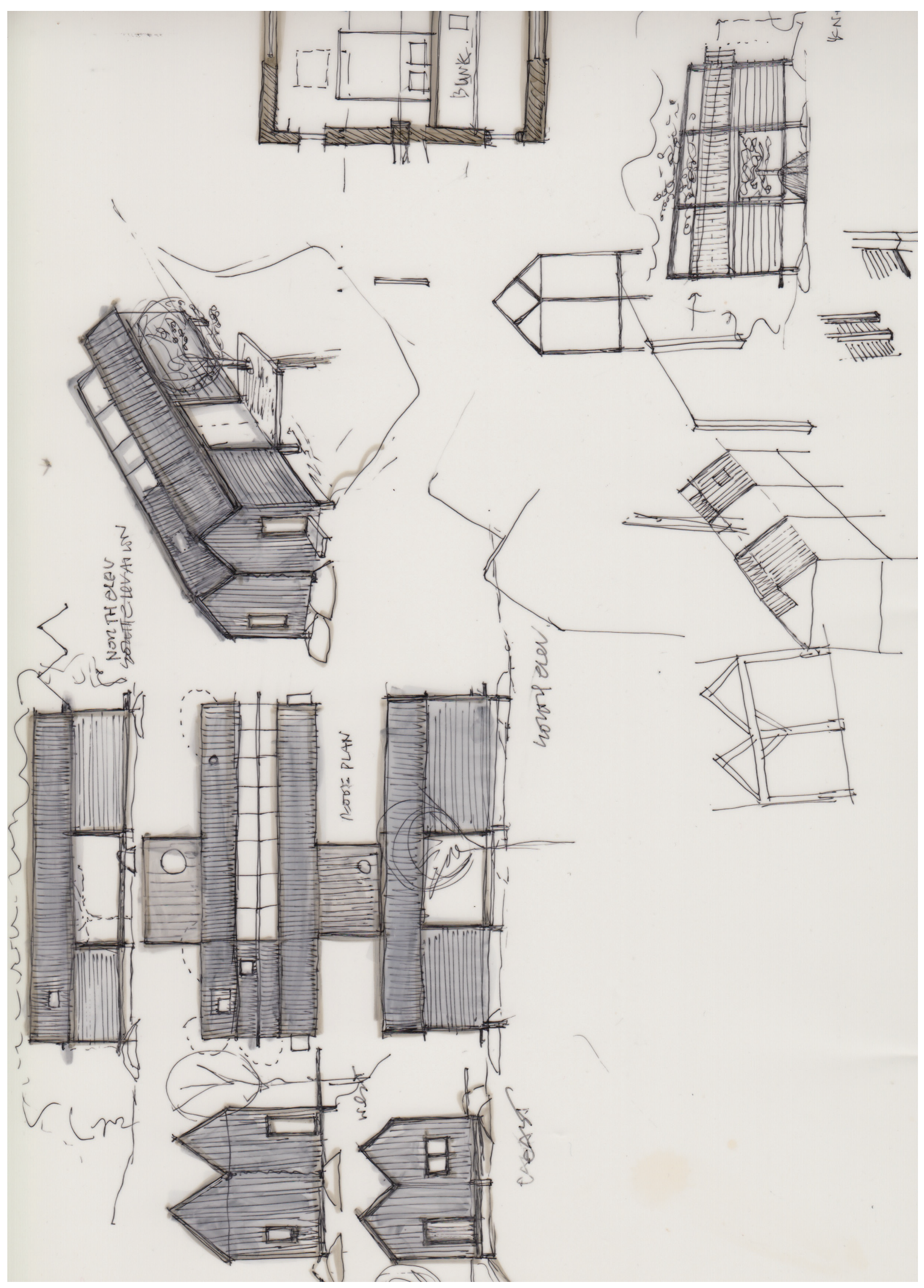




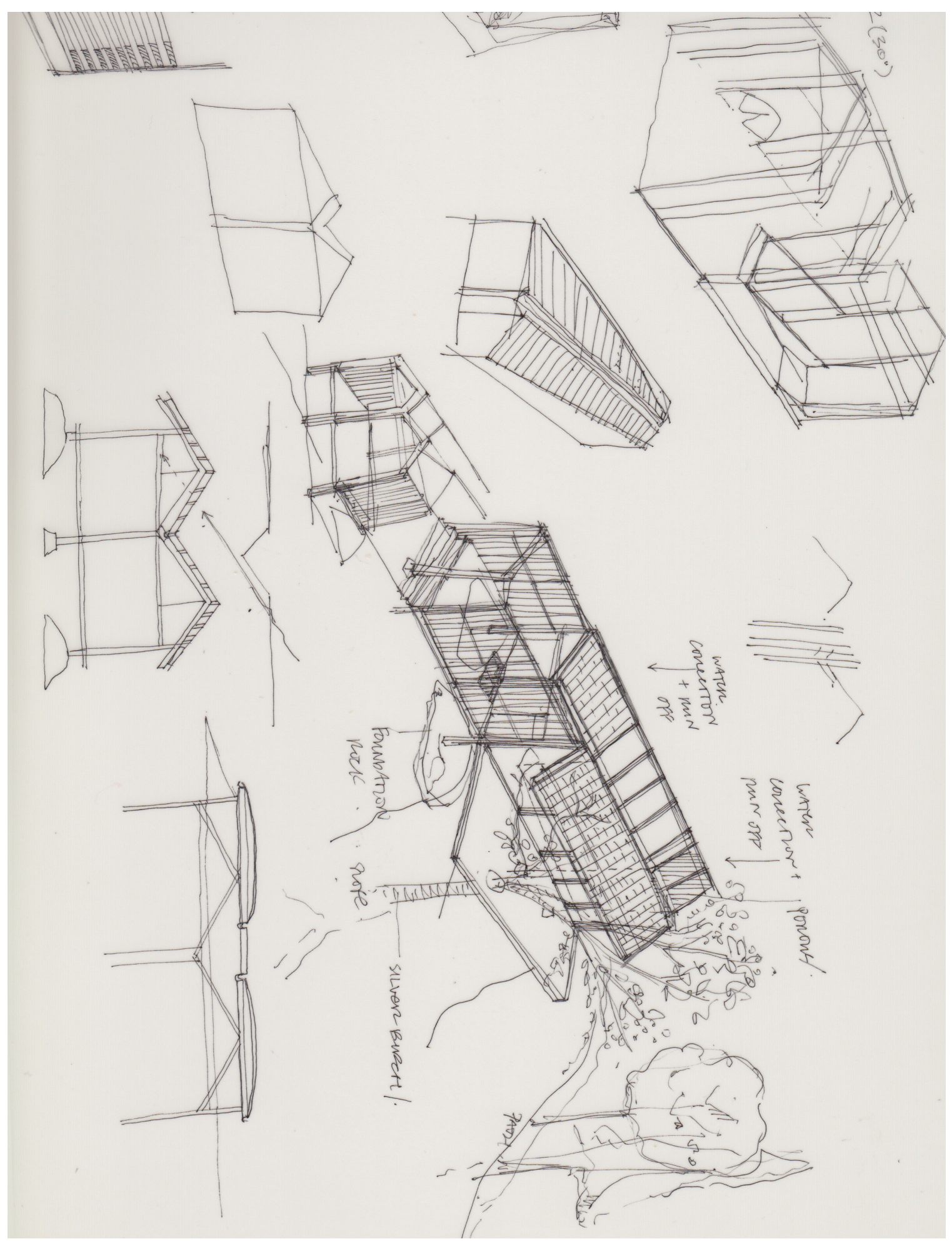




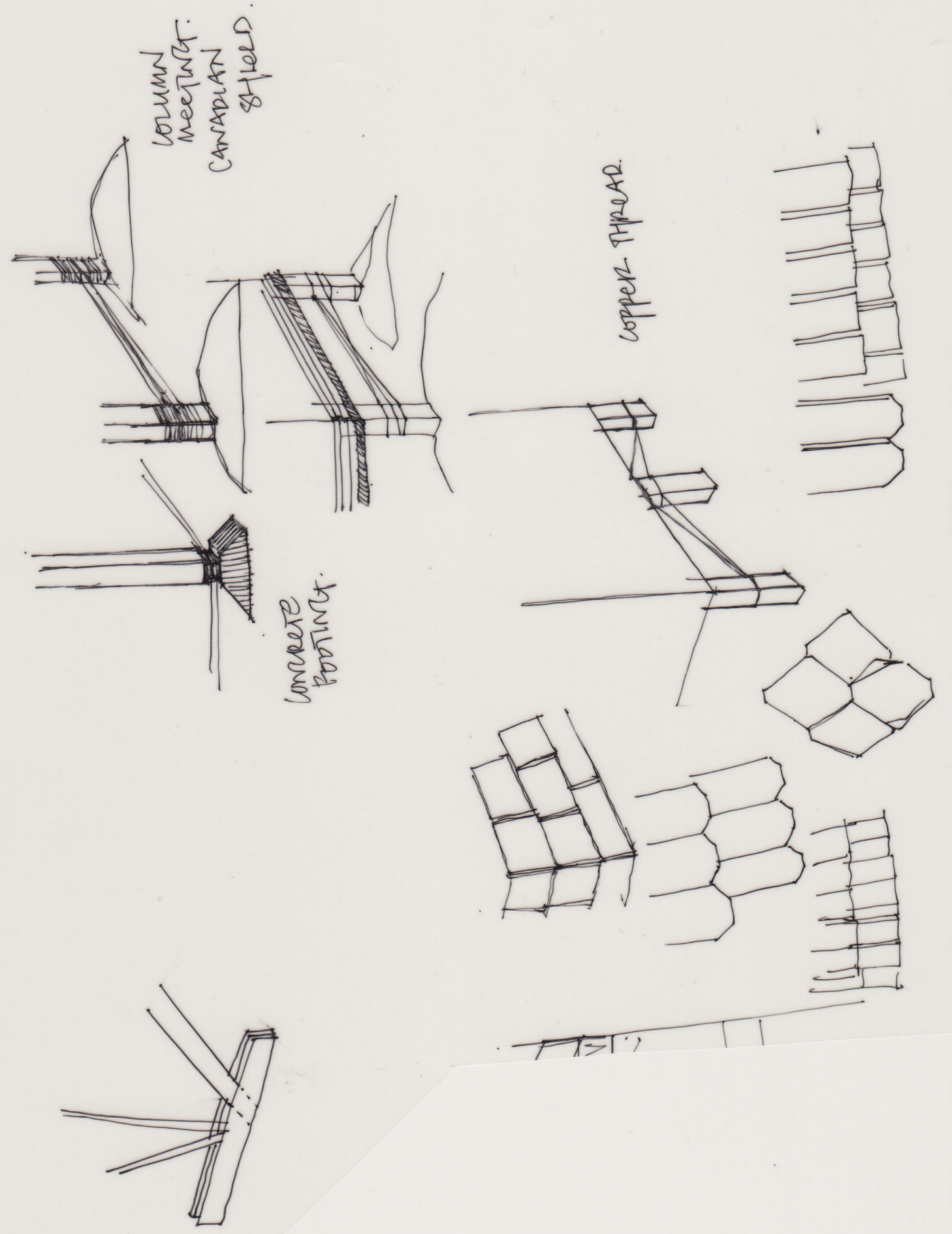




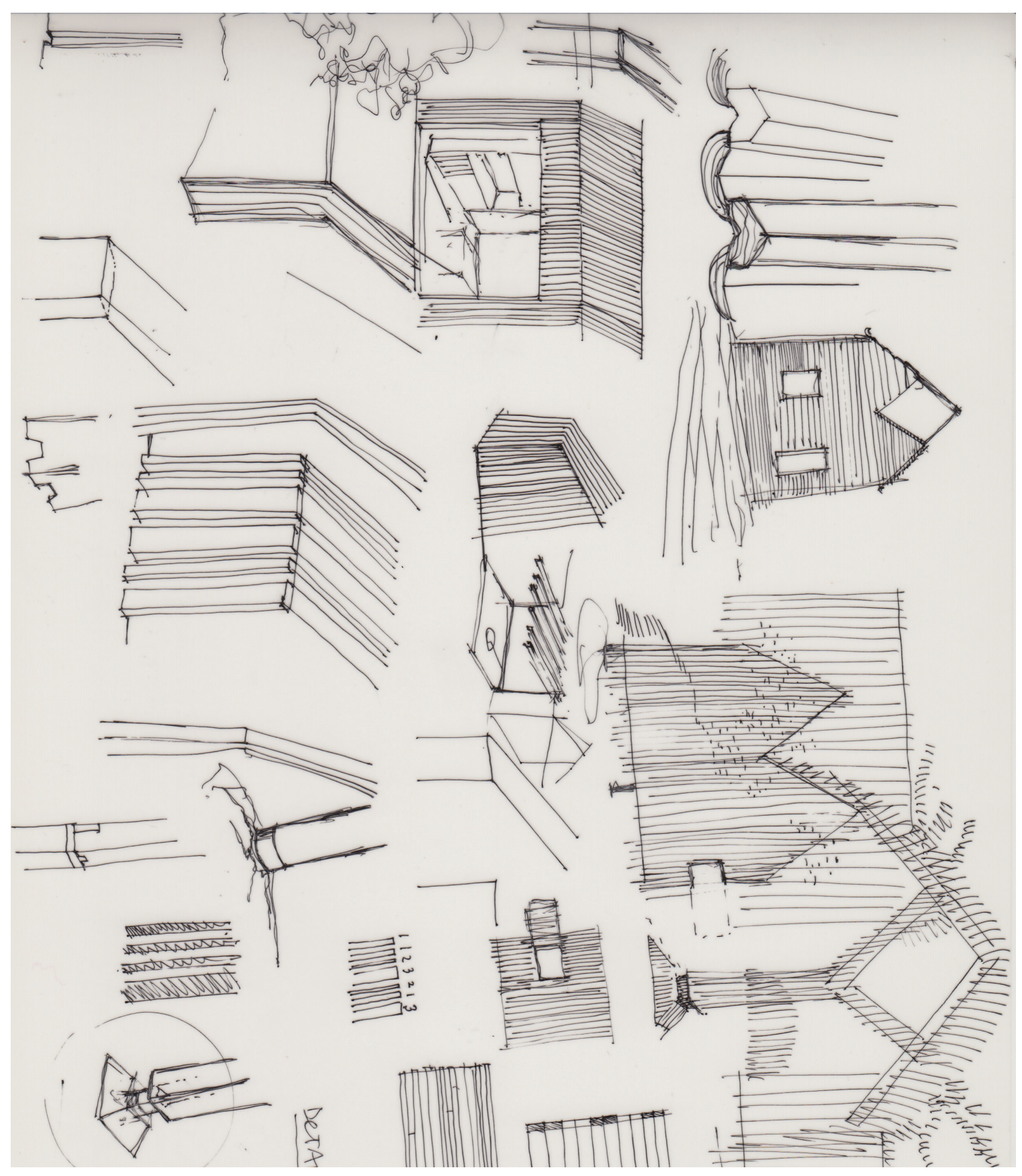




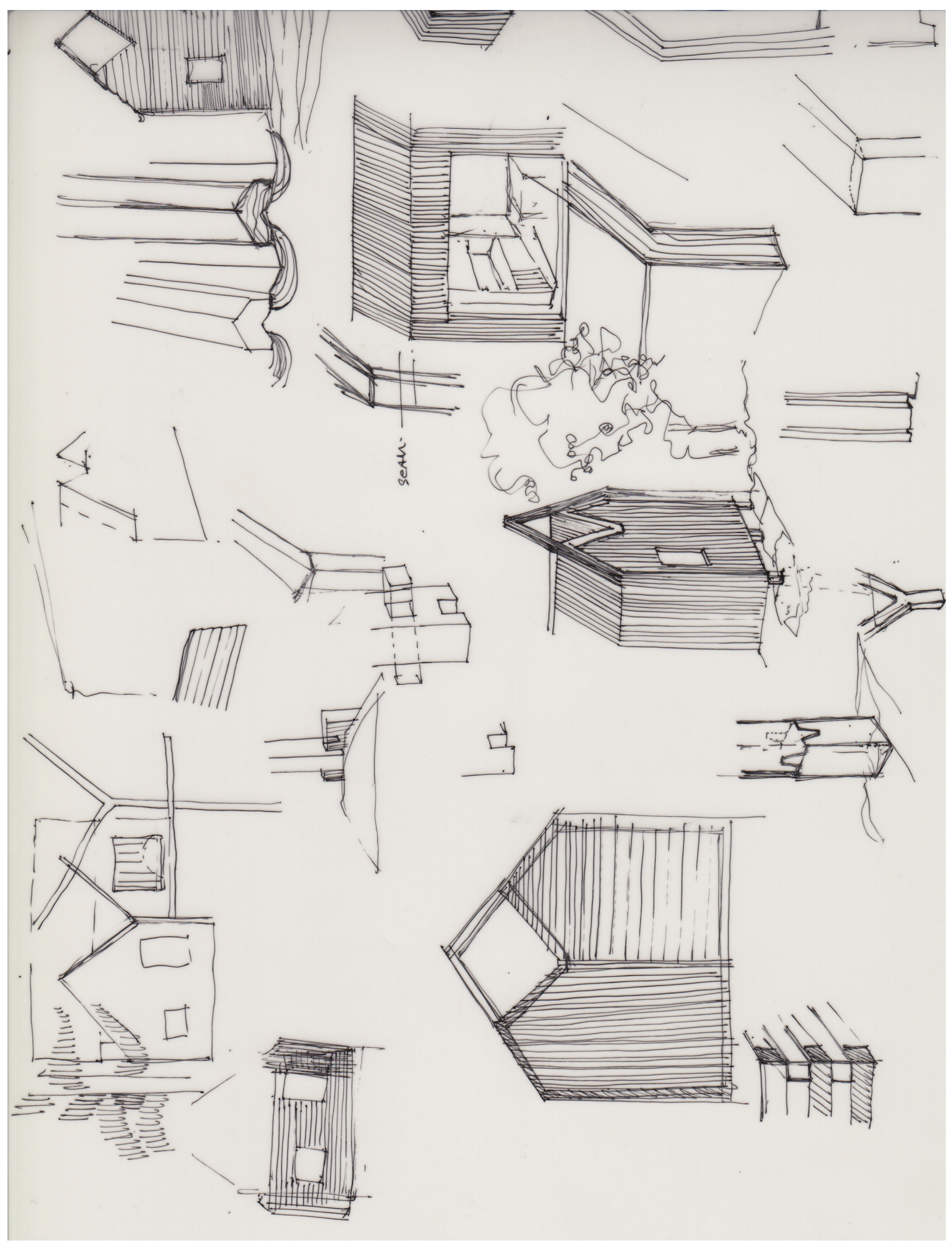




\section{A.2 Working Scaled Drawings on Mylar Paper: Considerably Altered Site Plans}

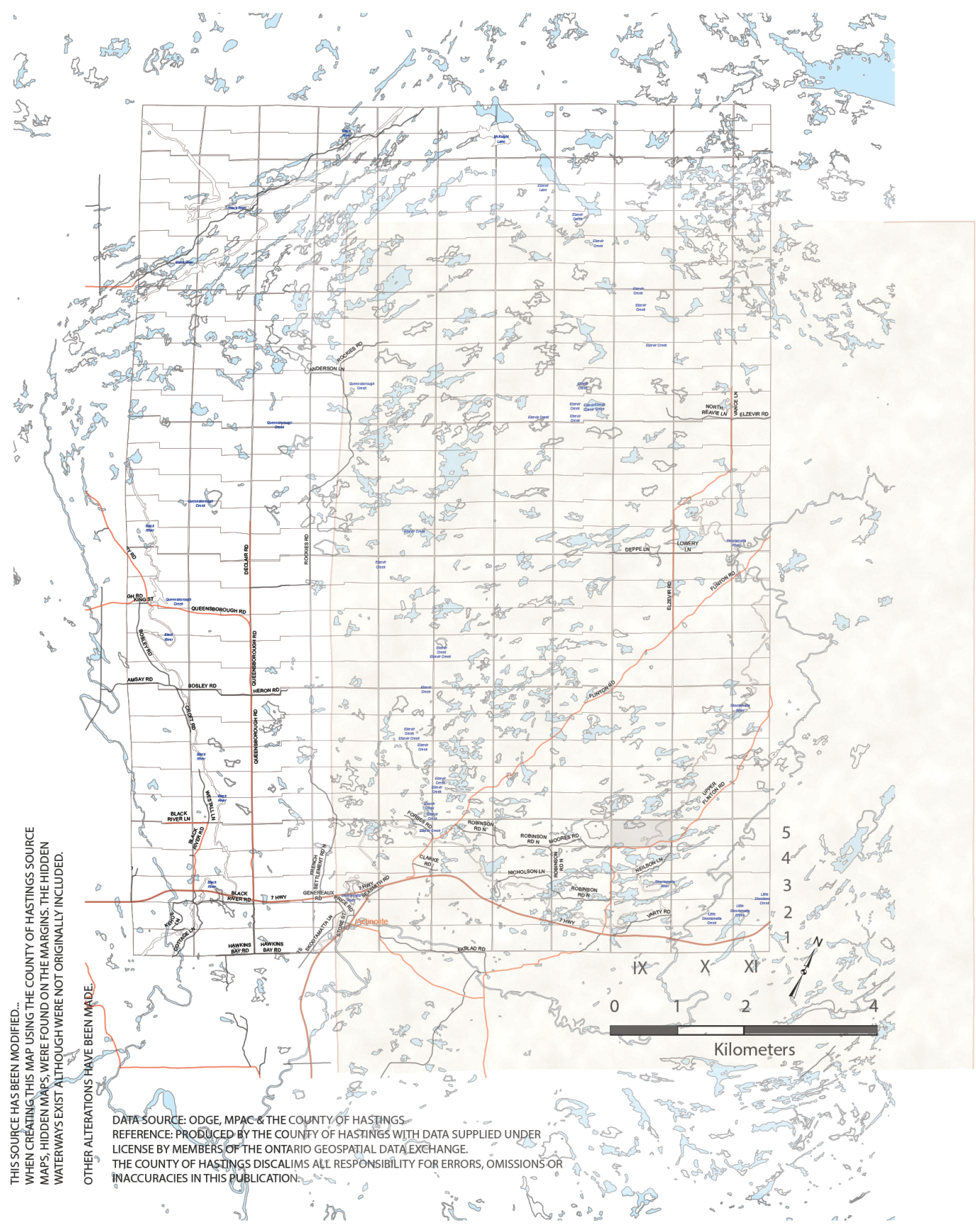




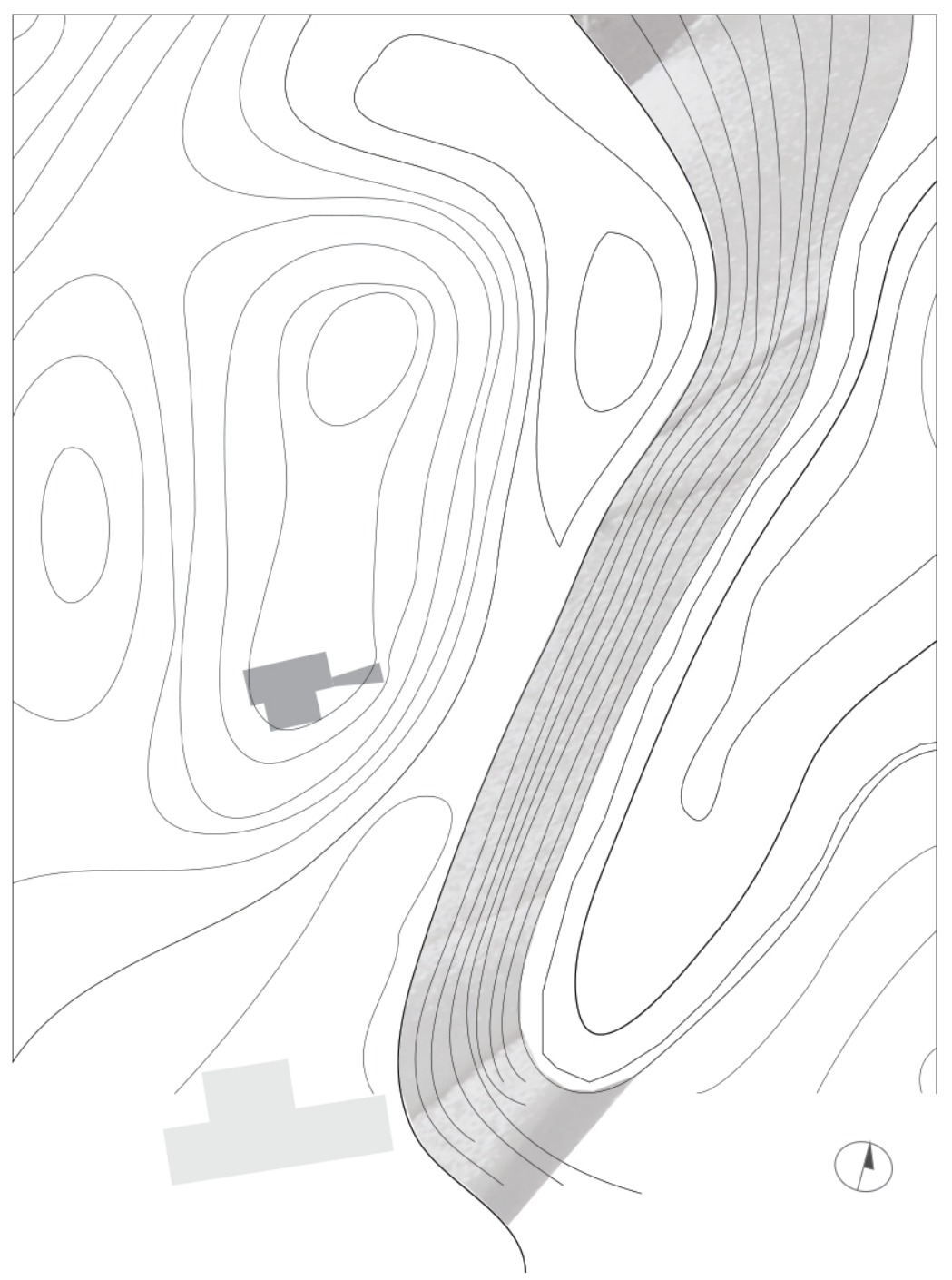

Map of Consideration: Site Plan with Topographic Contours at $1 \mathrm{~m}$

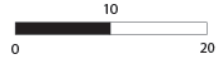




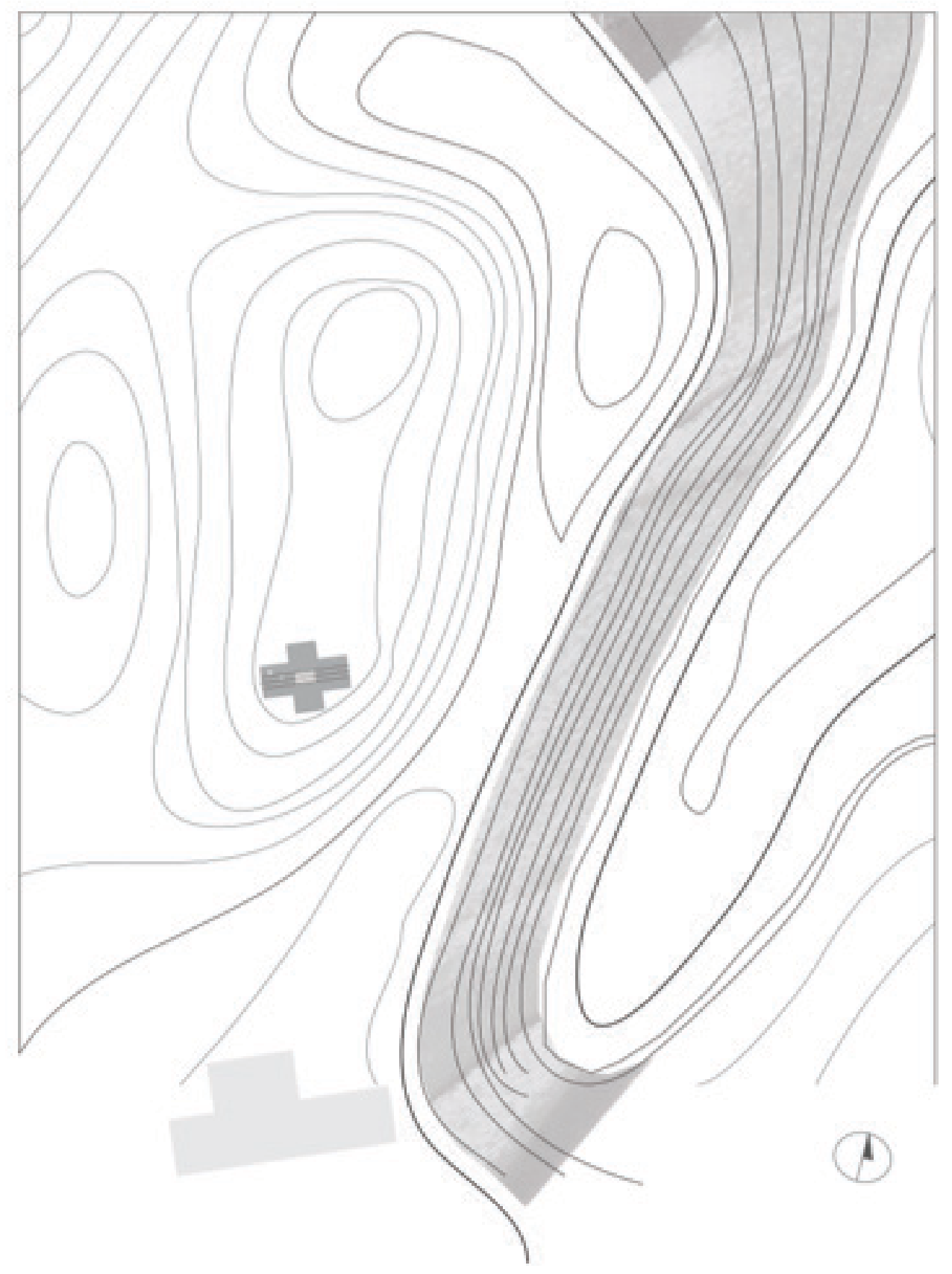

Map of Consideration: Site Plan with Topographic Contours

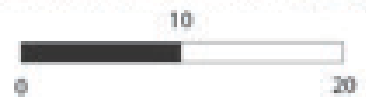




\section{A.3 Working Scaled Drawings on Mylar Paper: Ground Plan}

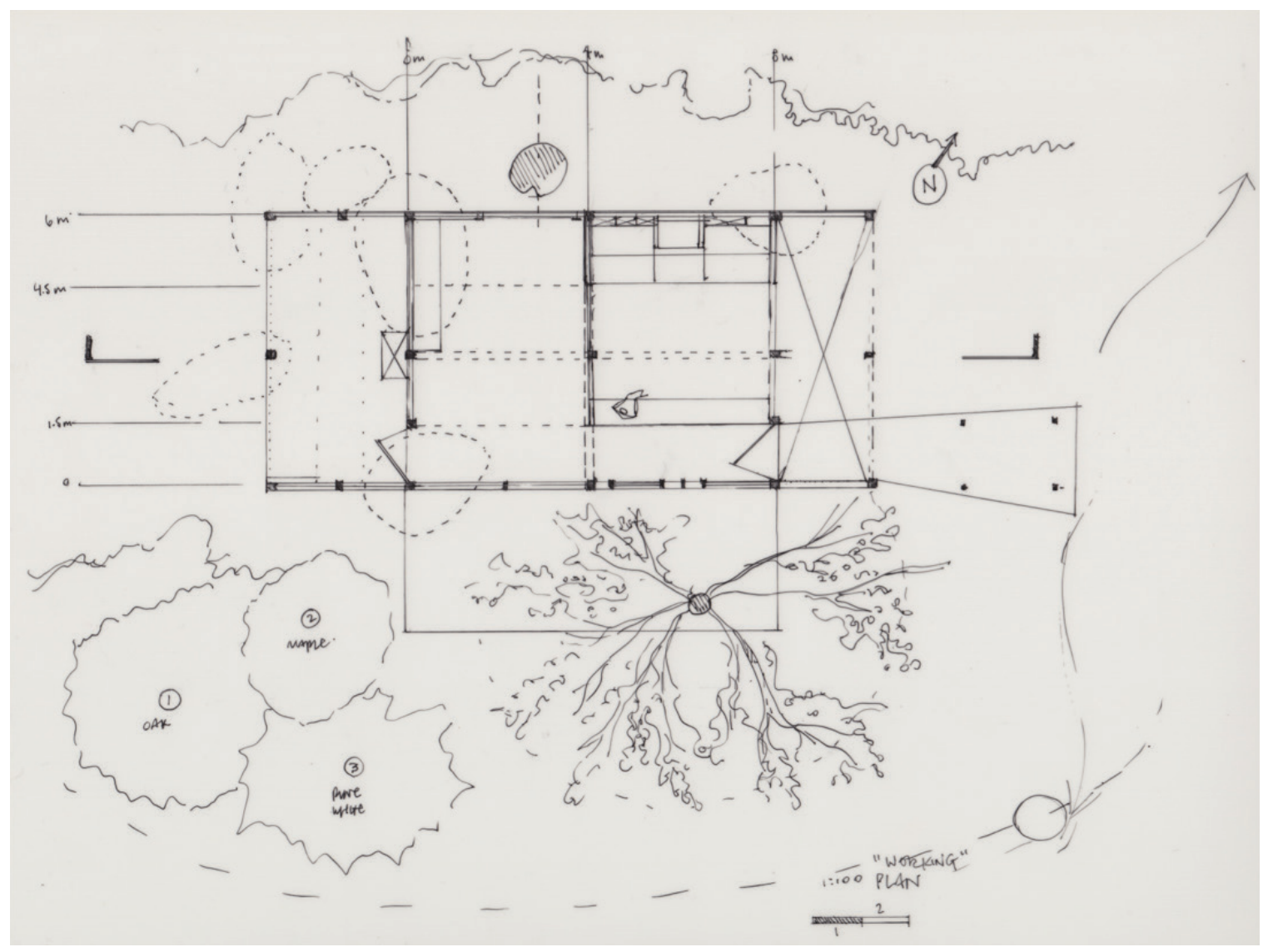




\section{A.4 Working Scaled Drawings on Mylar Paper: Elevations}

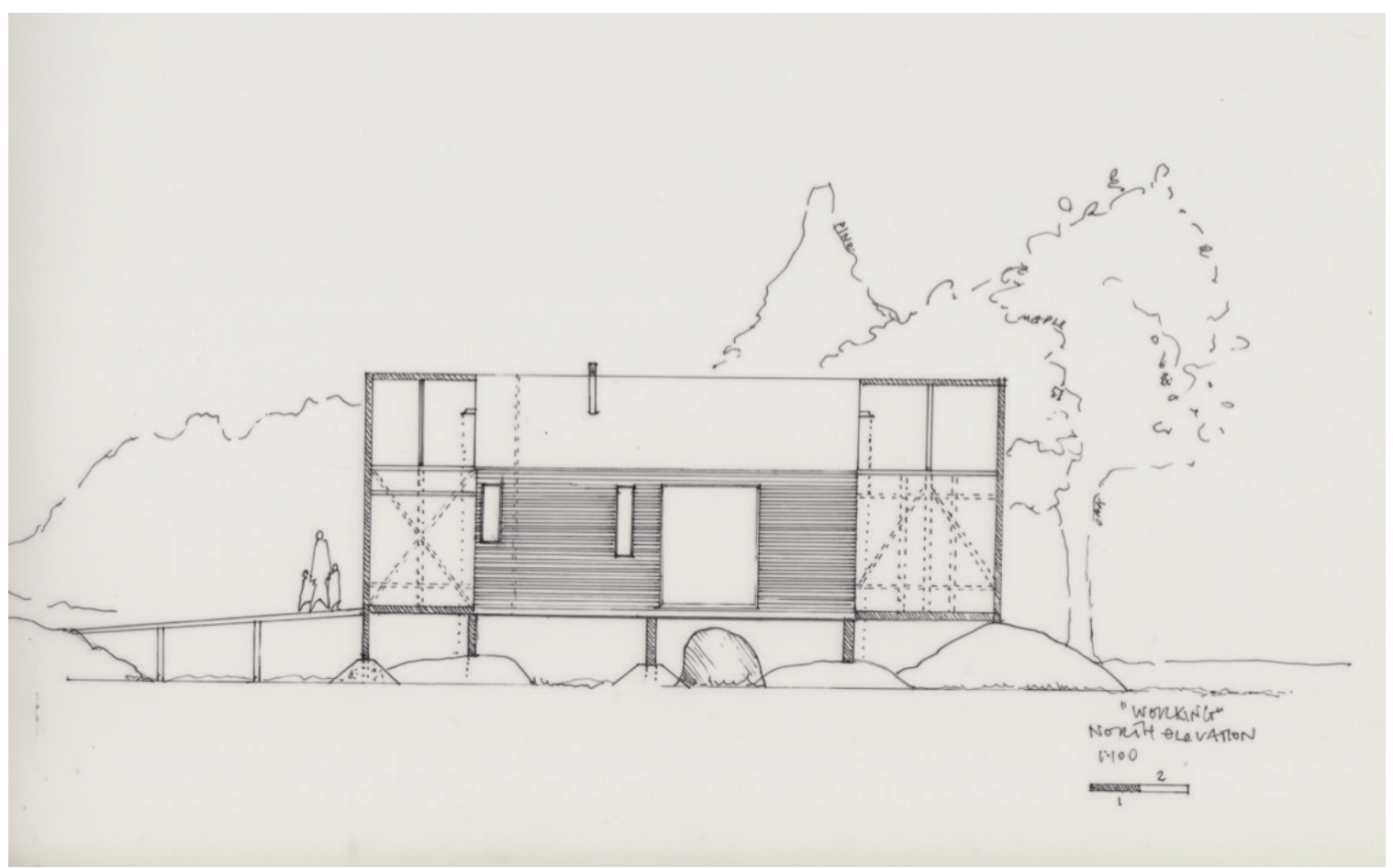




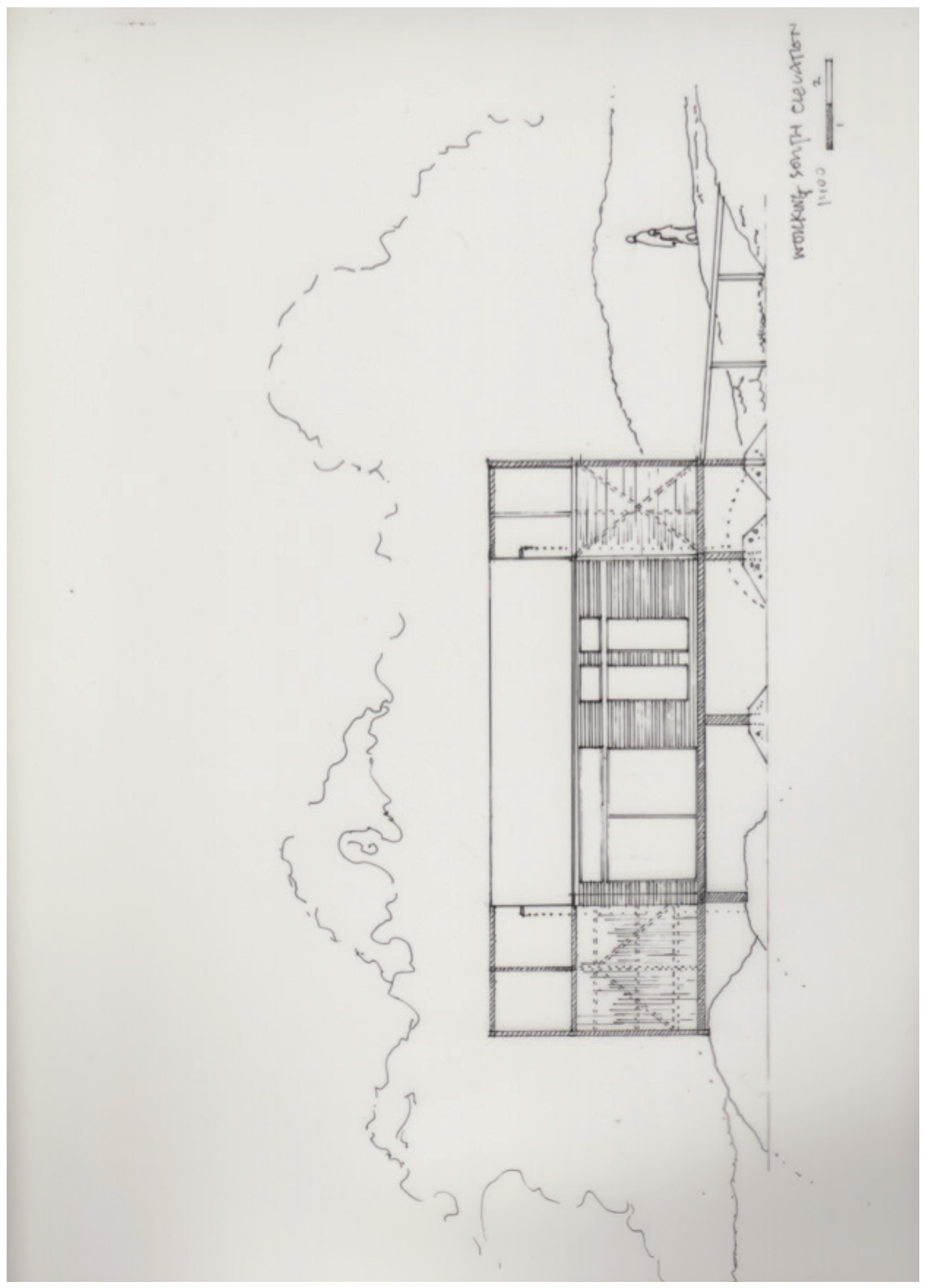



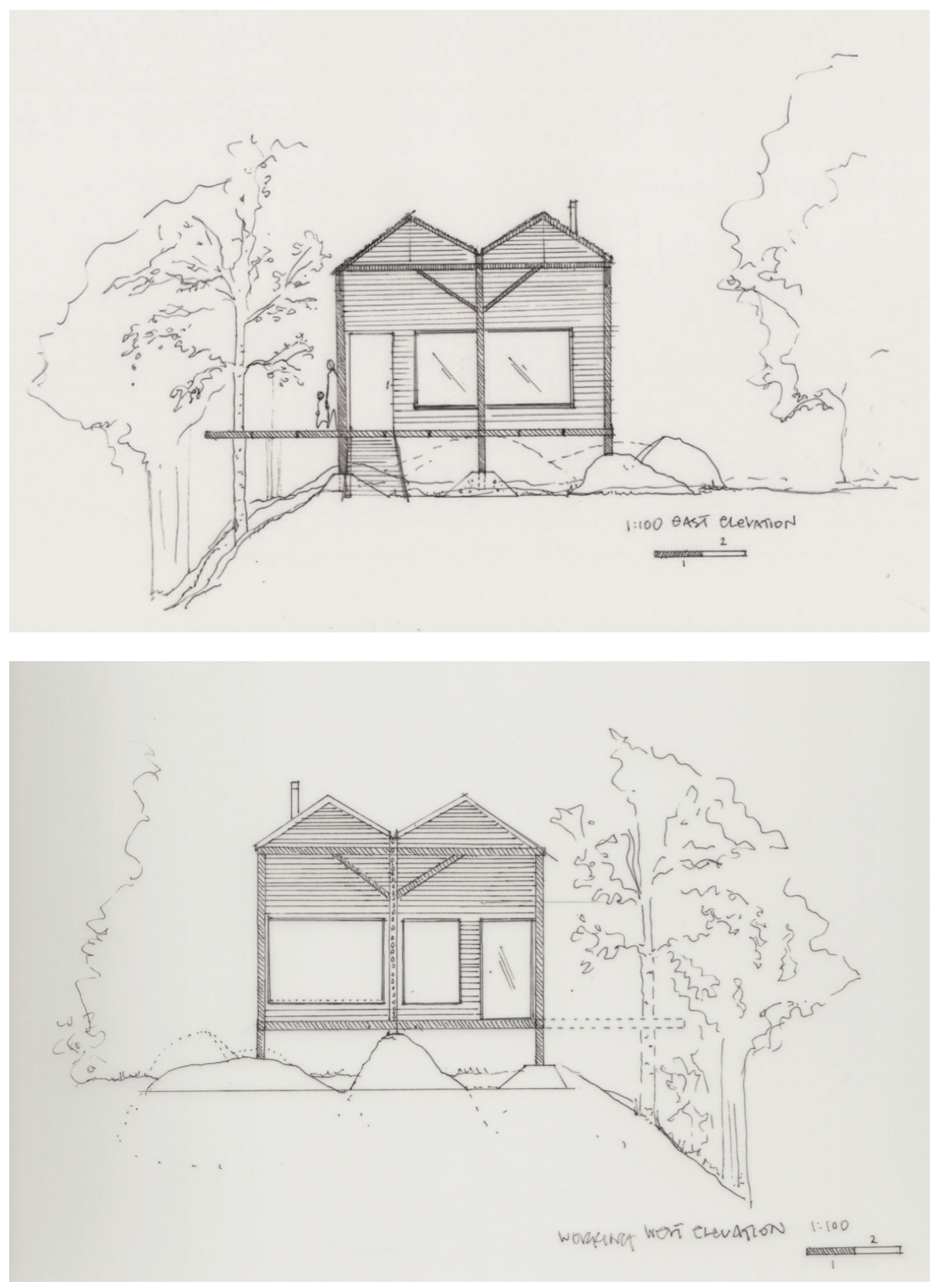


\section{A.5 Working Scaled Drawings on Mylar Paper: Section}

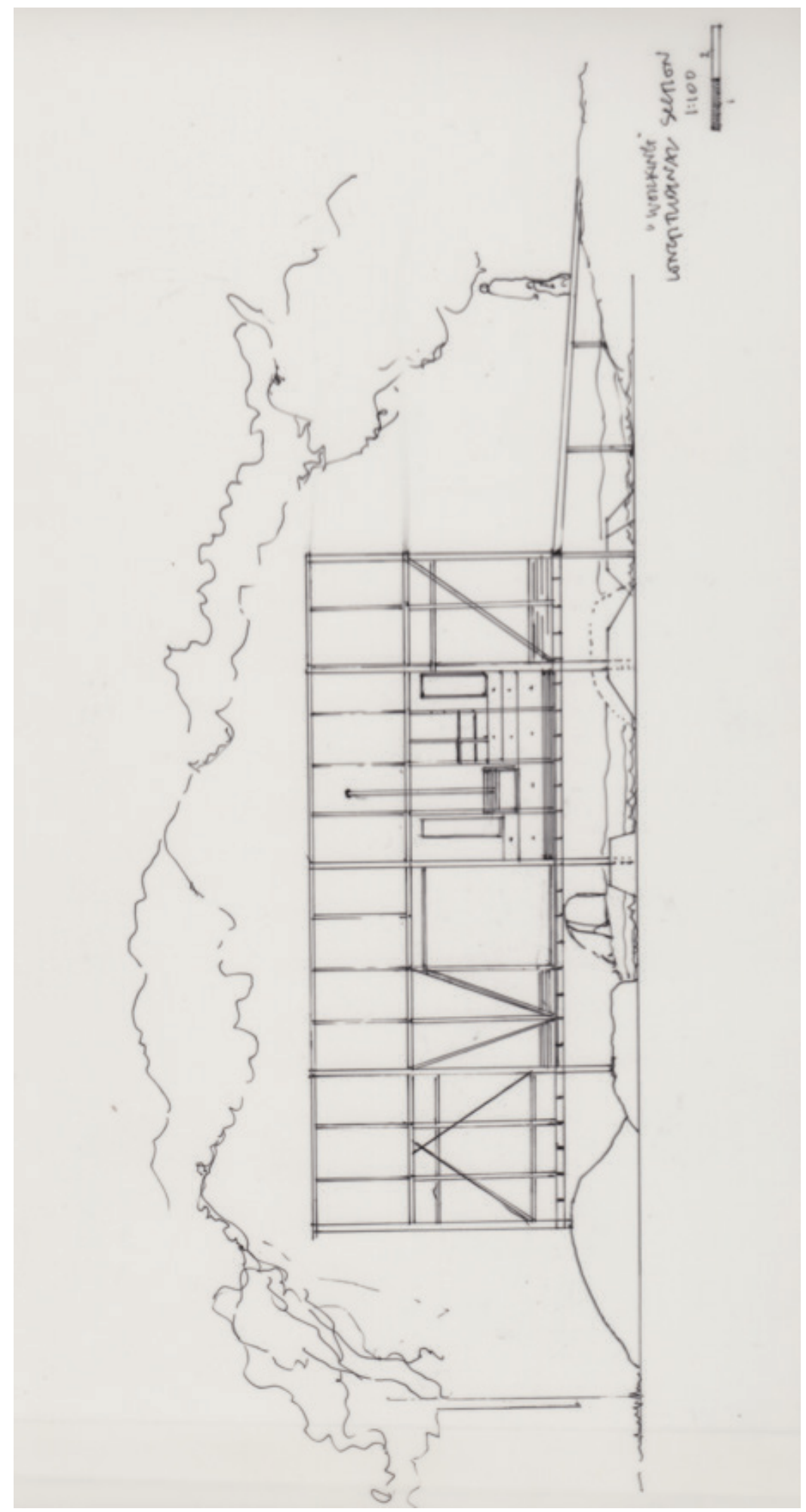




\section{Appendix B : Poetic References}

\section{B.1 The Country North of Belleville}

Bush land scrub land -

Cashel Township and Wollaston

Elzevir McClure and Dungannon

green lands of Weslemkoon Lake

where a man might have some

opinion of what beauty

is and none deny him

for miles -

Yet this is the country of defeat where Sisyphus rolls a big stone year after year up the ancient hills picknicking glaciers have left strewn with centuries' rubble

backbreaking days in the sun and rain

when realization seeps slow in the mind without grandeur or self-deception in noble struggle

of being a fool -

A country of quiescence and still distance a lean land

not like the fat south

with inches of black soil on earth's round belly -

And where the farms are it's as if a man stuck

both thumbs in the stony earth and pulled it apart

to make room

enough between the trees

for a wife

and maybe some cows and

room for some

of the more easily kept illusions -

And where the farms have gone back

to forest

are only soft outlines

shadowy differences -

Old fences drift vaguely among the trees

a pile of moss-covered stones 
gathered for some ghost purpose

has lost meaning under the meaningless sky

- they are like cities under water

and the undulating green waves of time

are laid on them -

This is the country of our defeat

and yet

during the fall plowing a man

might stop and stand in a brown valley of the furrows

and shade his eyes to watch for the same

red patch mixed with gold

that appears on the same

spot in the hills

year after year

and grow old

plowing and plowing a ten-acre field until

the convolutions run parallel with his own brain -

And this is a country where the young

leave quickly

unwilling to know what their fathers knew

or think the words their mothers do not say -

Herschel Monteagle and Faraday

lakeland rockland and hill country

a little adjacent to where the world is

a little north of where the cities are and

sometime

we may go back there

to the country of our defeat

Wollaston Elzevir and Dungannon

and Weslemkoon lake land

where the high townships of Cashel

McClure and Marmora once were -

But it's been a long time since

and we must enquire the way

of strangers -

Al Purdy

Beyond Remembering: The Collected Poems of Al Purdy 


\section{B.2 Trading Cities}

In Ersilia, to establish the relationships that sustain the city's life, the inhabitants stretch strings from the corners of the houses, white or black or gray or black-and-white according to whether they mark a relationship of blood, of trade, authority, agency. When the strings become so numerous that you can no longer pass among them, the inhabitants leave: the houses are dismantled; only the strings and their supports remain.

From a mountainside, camping with their household goods, Ersilia's refugees look at the labyrinth of taut strings and poles that rise in the plain. That is the city of Ersilia still, and they are nothing.

They rebuild Ersilia elsewhere. They weave a similar pattern of strings which they would like to be more complex and at the same time more regular than the other. Then they abandon it and take themselves and their houses still farther away. Thus, when traveling in the territory of Ersilia, you come upon the ruins of abandoned cities, without the walls which do not last, without the bones of the dead which the wind rolls away: spiderwebs of intricate relationships seeking a form.

Italo Calvino

Invisible Cities 


\section{Appendix C : Final Design Drawings}

\section{C.1 Plan}

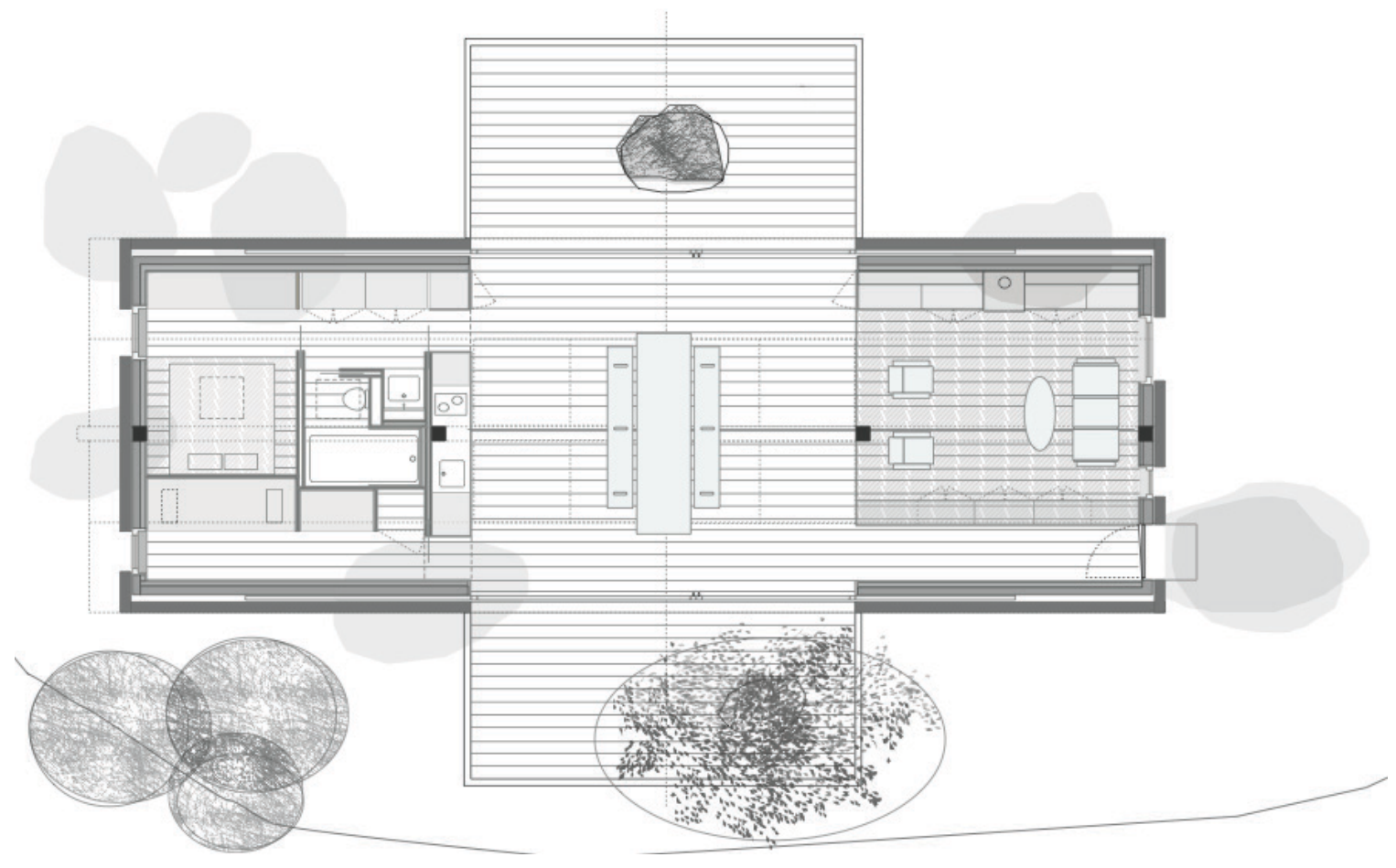




\section{C.2 East Elevation}

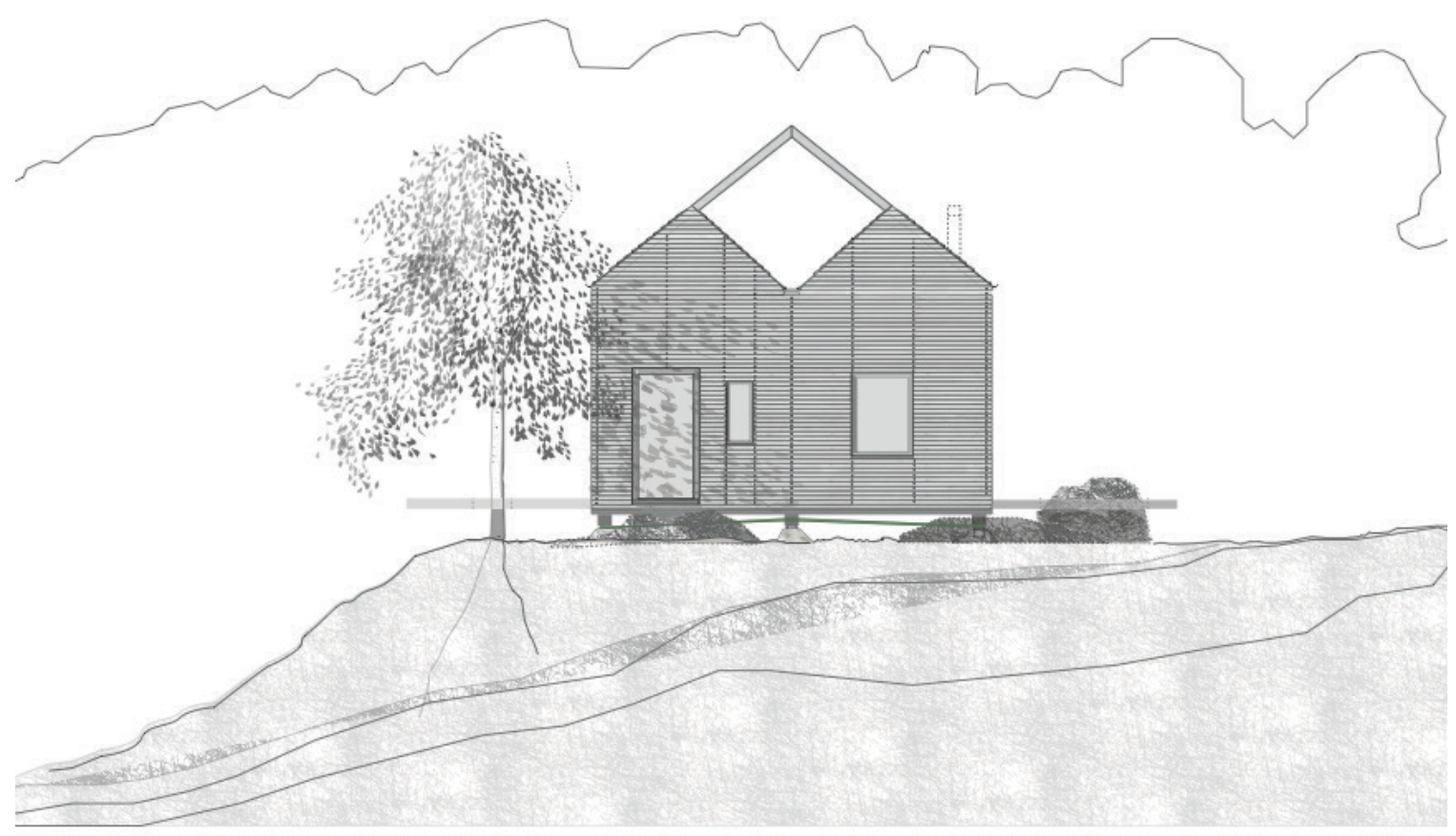

\section{C.3 West Elevation}

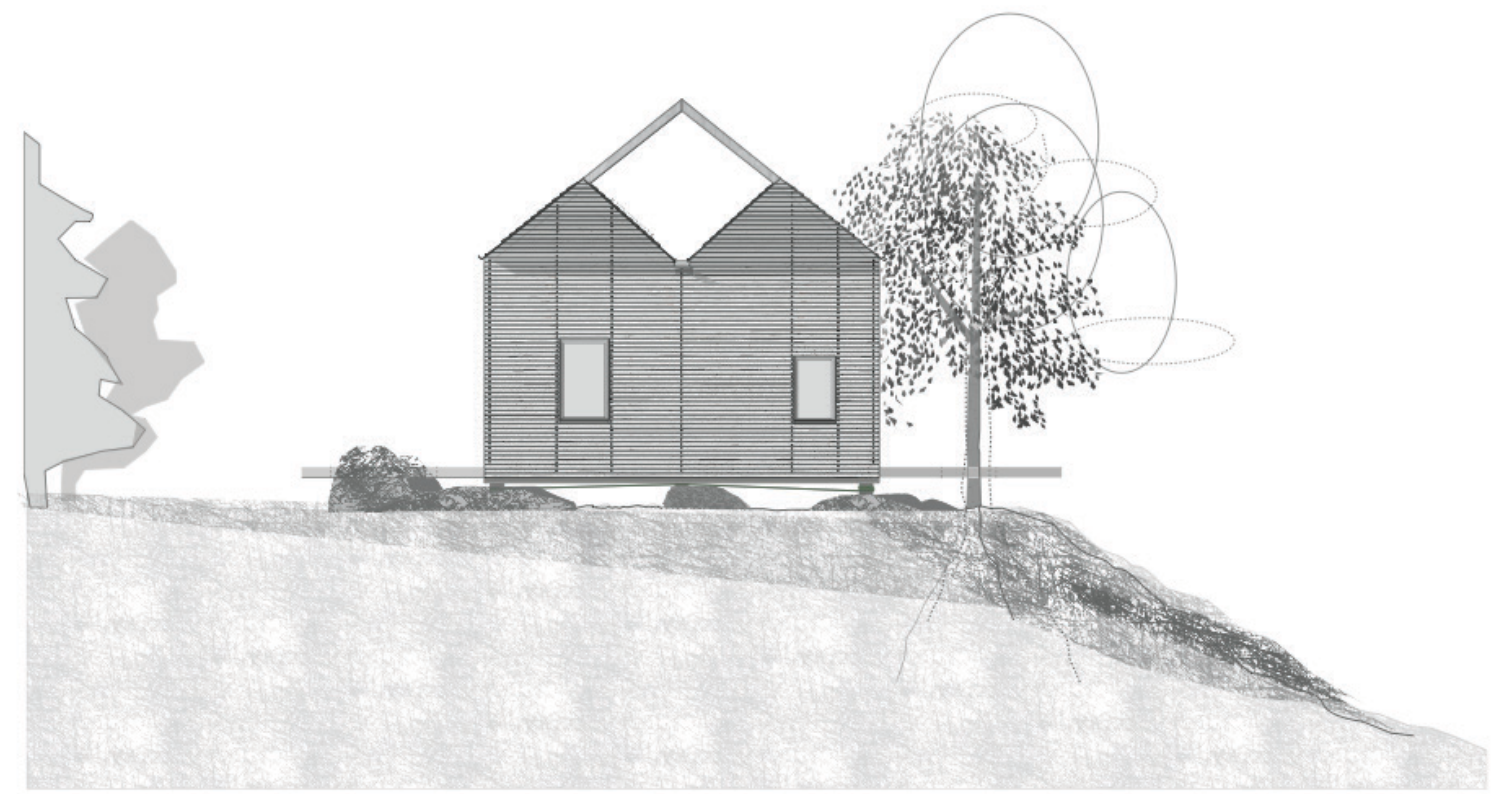




\section{C.4 South Elevation}

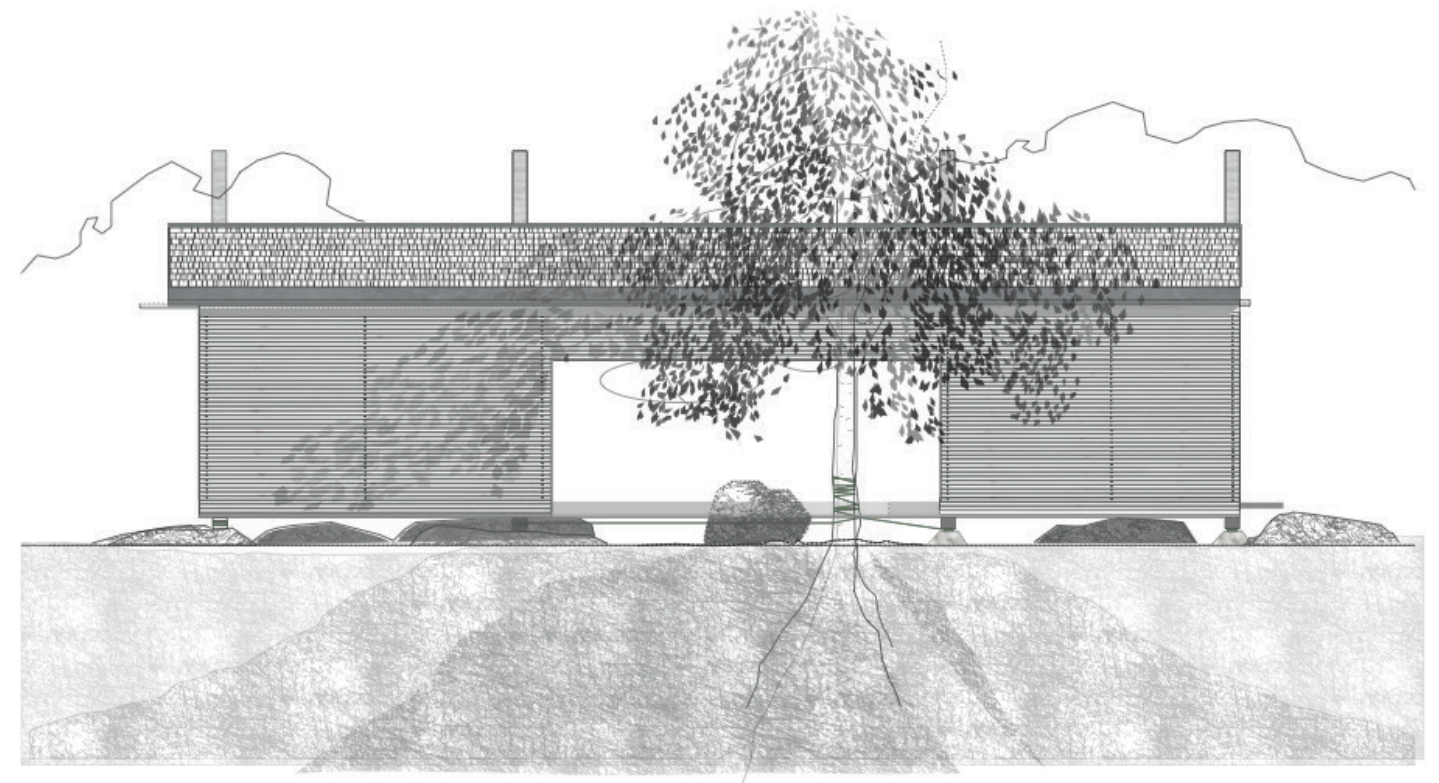

\section{C.5 North Elevation}

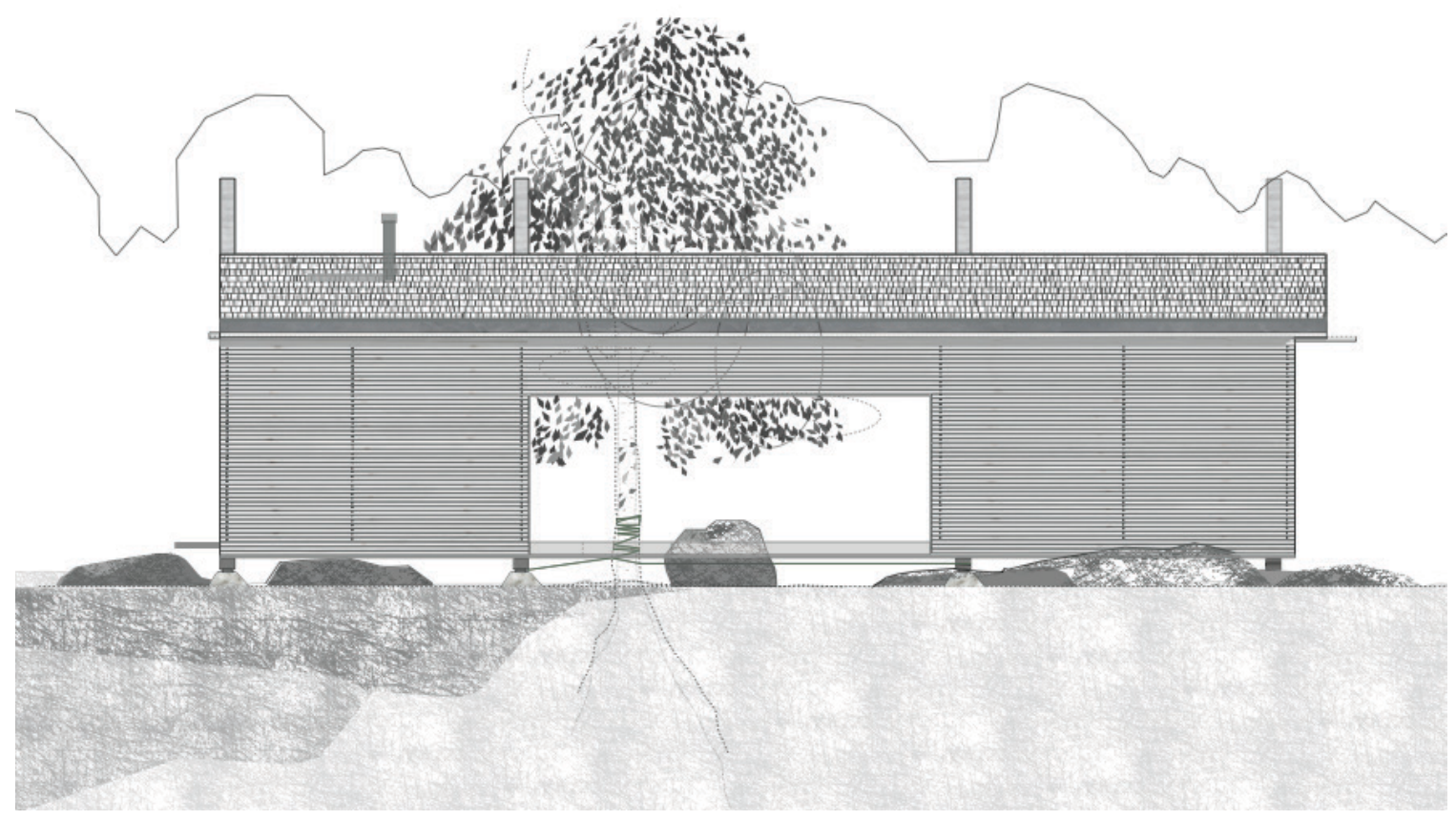




\section{C.6 Cross Section}

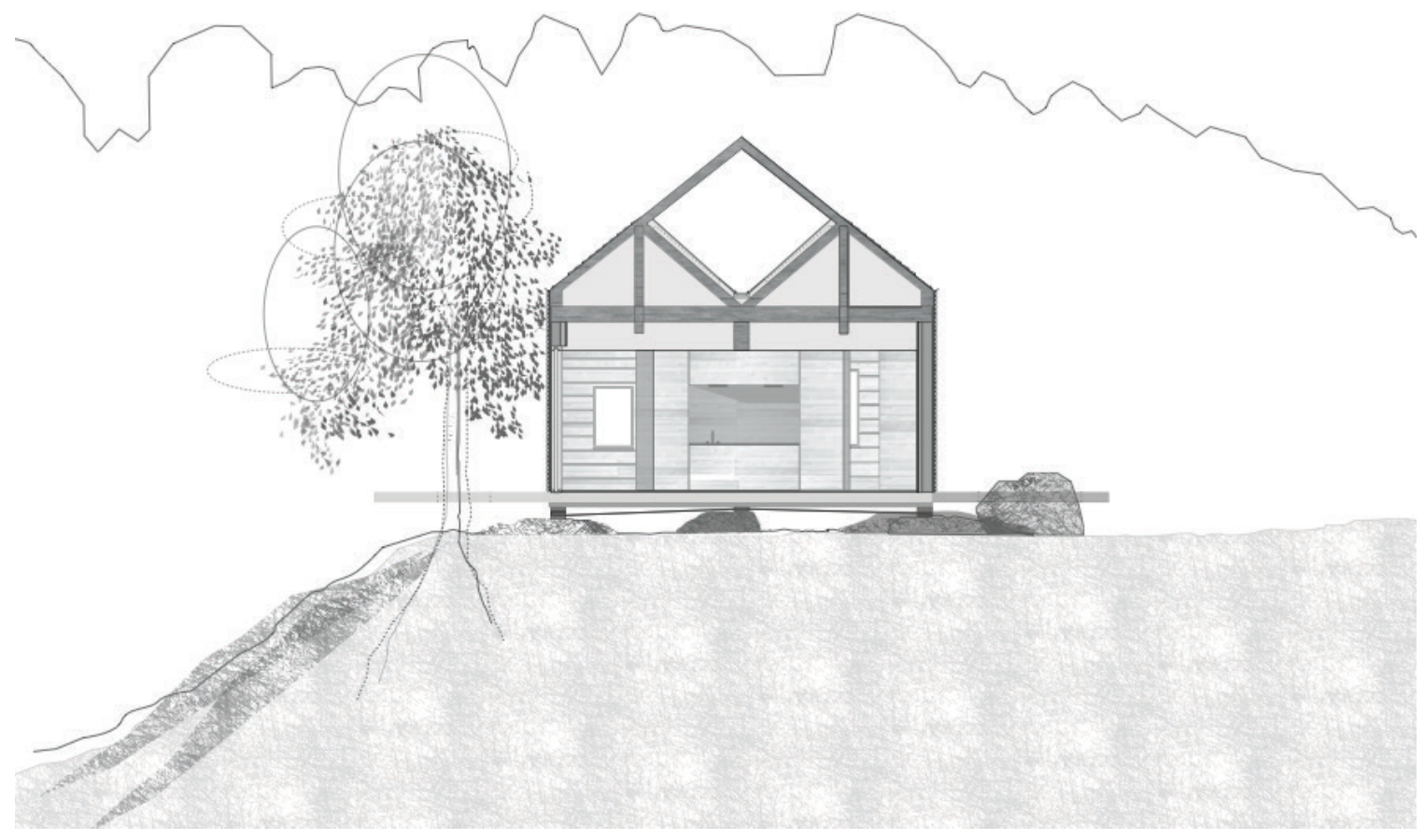

\section{C.7 Longitudinal Section}

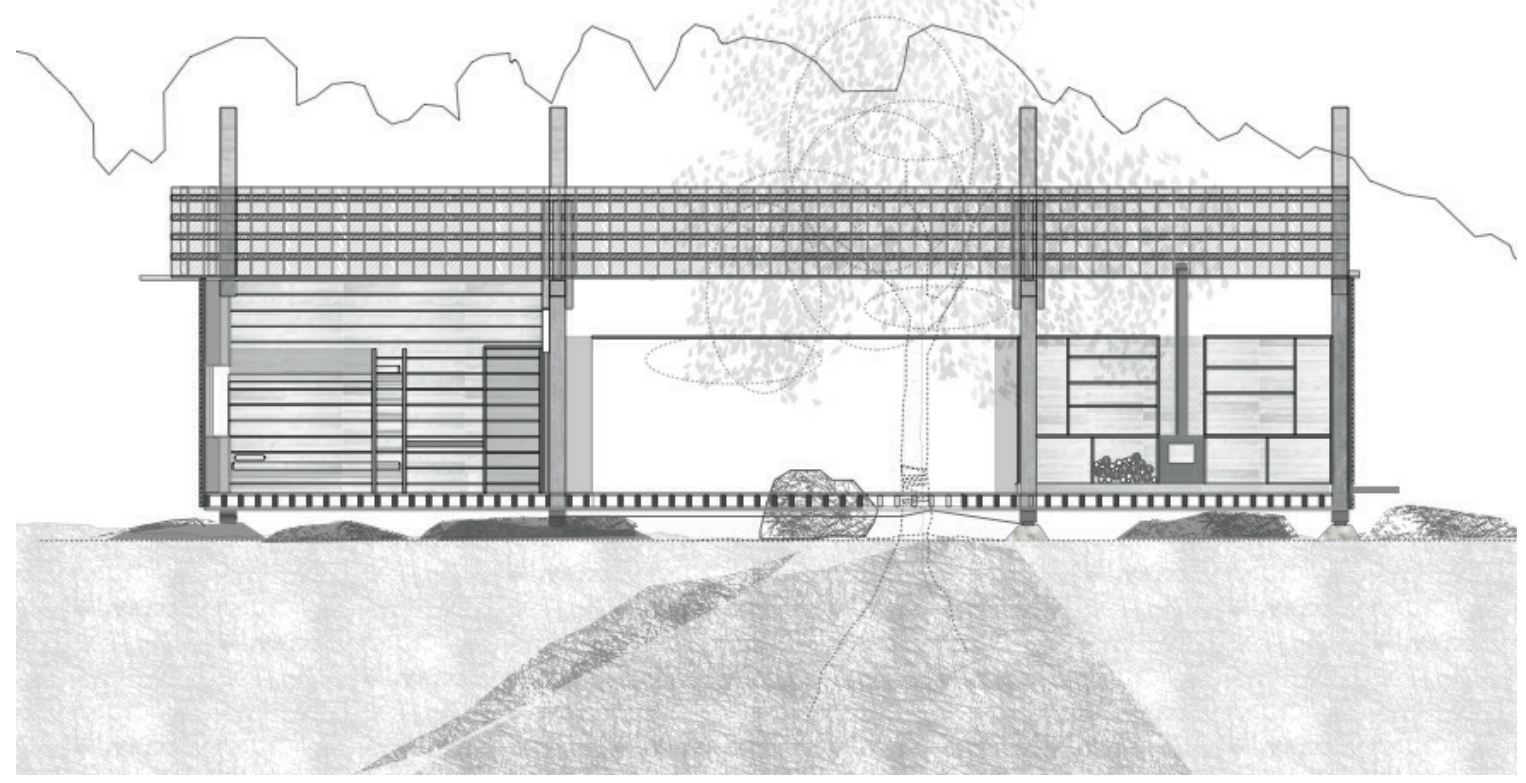




\section{C.8 Exploded Axonometric}

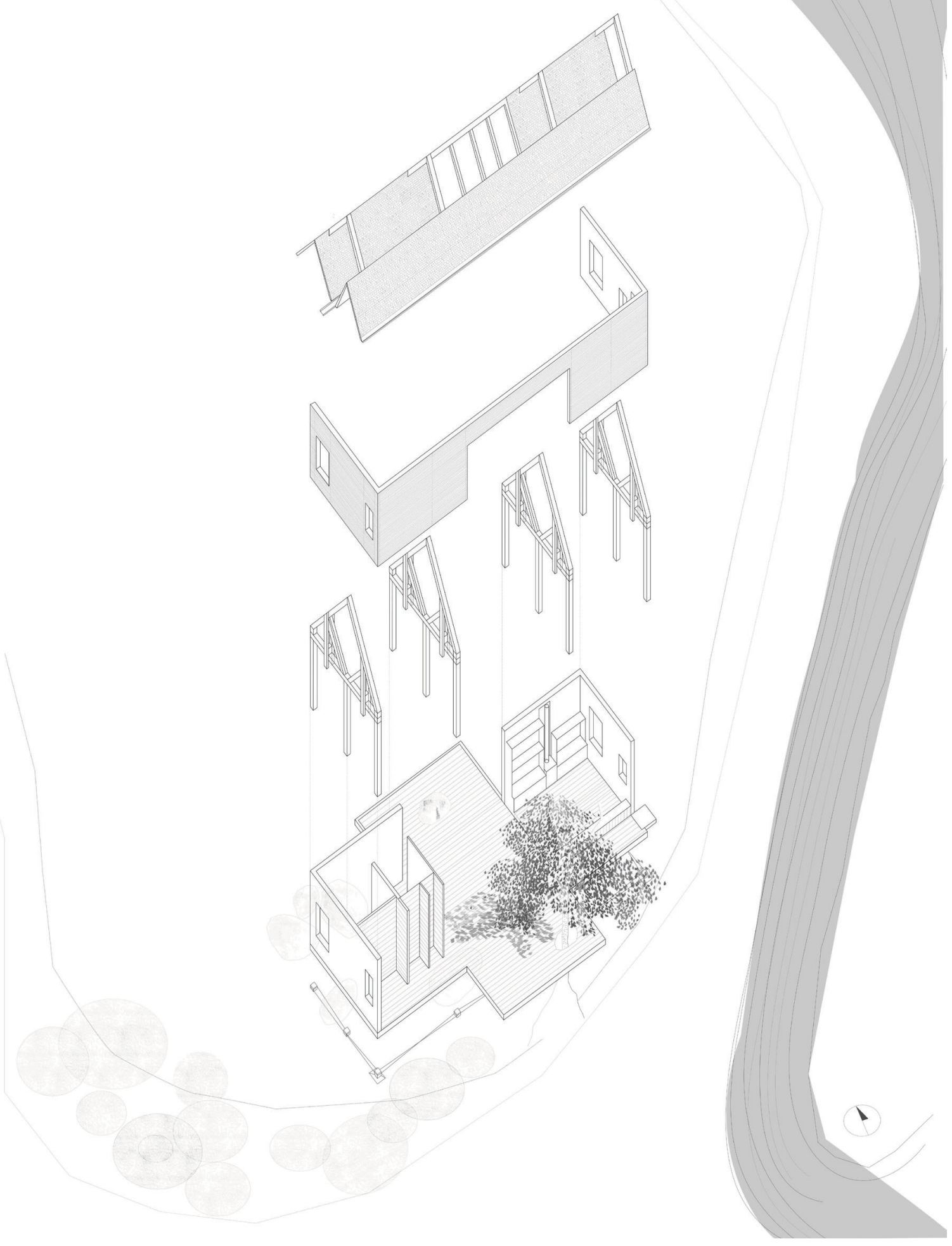




\section{C.9 Analytique Drawing}

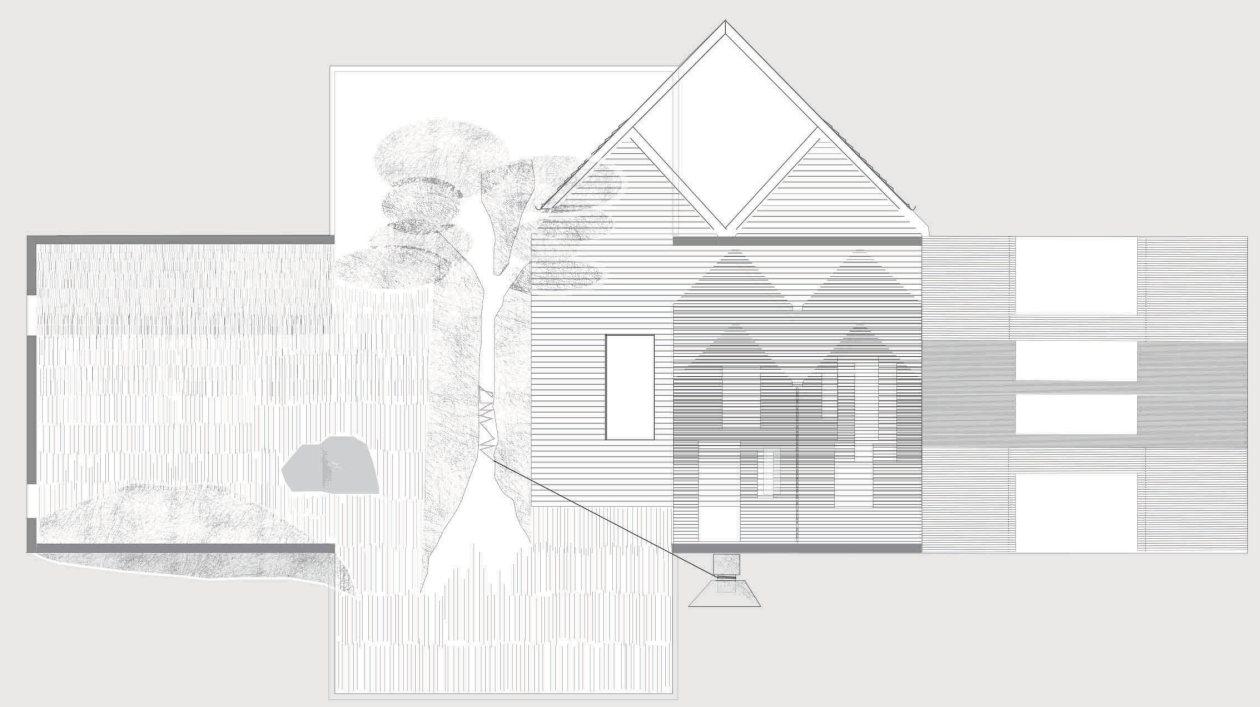




\section{References}

AGAMBEN, GIORGIO. What is the Contemporary? Redwood City: Stanford University Press, 2009.

ALBERTI, LEON BATTISTA. On Painting. London: Penguin Books Ltd., 1972.

AUDI, ROBERT, The Cambridge Dictionary of Philosophy, $2^{\text {nd }}$ Edition. Cambridge University Press, 1999.

AXFORD, MARGARET. The Oxen and the Axe. Cloyne, Ont: Cloyne and District Historical Society, 2008.

BACHELARD, GASTON, The Poetics of Space, translated by Maria Jolas, Boston: Beacon Press, 1969.

BERGER, JOHN. Bento's Sketchbook. London: Verso, 2011.

BENJAMIN, WALTER. The Work of Art in the Age of Technological Reproducibility, Cambridge: Belknap Press of Harvard University Press, 2008.

BENJAMIN, WALTER. Illuminations: Essays and Reflections. London: Pimlico Random House, 1999. 
BERGER, JOHN and MOHR, JEAN. Another Way of Telling. New York: Vintage Books, 1995.

BERGER, JOHN. Ways of Seeing. London: Penguin Books, 1972.

BERRIZBEITIA, ANITA and POLLAK, LINDA. Inside Outside: Between Architecture and Landscape. Gloucester, MA: Rockport Publishers, 1999.

BORGES, J. L. Collected Fictions (Trans. Hurley, H.) London: Penguin Books. 1999.

BOYCE, GERALD, E. Historic Hastings. Hastings City Council, 1967.

CALVINO, ITALO. Six Memos for the Next Millennium. London: Vintage Books, 1996.

CALVINO, ITALO. Collection of Sand (Trans. Martin McLaughlin) London: Penguin Classics. 2002

CALVINO, ITALO, Invisible Cities. London: Picador, 1974.

CLOYNE AND DISTRICT HISTORICAL SOCIETY. The Oxen and the Axe, second edition, 2008. 
CONNAH, ROGER. How Architecture Got its Hump. Cambridge MA: MIT Press, 2001.

CONNAH, ROGER ed. The Ark of Architecture: Selected Writings of Malcolm Quantrill. Helsinki: Rakennustieto Publishing, 2008.

DAYER, CAROLINA and EMMONS, PAUL. Marcia Feuerstein ed. Architecture as a Performing Art. London: Ashgate, 2013.

ECO, UMBERTO. The Limits of Interpretation. Indiana University Press, 1990.

EMMONS, PAUL and FOOTE, JONATHAN. "Making Plans: Albertis’ Ichnography as Cultural Artefact" in Adam Sharr ed. Reading Architecture and Culture: Researching Buildings, Spaces and Documents. London: Routledge, 2012.

FRAMPTON, KENNETH. The Evolution of 20th Century Architecture: A Synoptic Account. New York: Springer Wien, 2007.

FRAMPTON, KENNETH. Modern Architecture: A Critical History. London: Thames \& Hudson, 2004.

FRASCARI, MARCO, HALE, JONATHAN and STARKEY, BRADLEY. From Models to Drawings: Imagination and Representation in Architecture. London: Routledge, 2007. 
FRASCARI, MARCO. Eleven Exercises in the Art of Architectural Drawing: Slow Food for the Architect's Imagination. London: Routledge, 2011.

GADAMER, HANS-GEORG. Truth and Method. London: Continuum International Publishing Group, 1989.

GIEDION, SIGFRIED. Time and Architecture: The Growth of a New Tradition. Boston: Harvard University Press. Revised edition, 1969.

GOFFI, FEDERICA. Time Matter[s]: Invention and Re-Imagination in Built Conservation the Unfinished Drawing and Building of St. Peter's, the Vatican. London: Ashgate, 2013.

GRAY M. et al, Carl Schaefer. Toronto: Gage Publishing Ltd. 1977.

HARRIES, KARSTEN. The Ethical Function of Architecture. Cambridge, MA: MIT Press, 1998.

HEJDUK, JOHN. Mask of Medusa: Works 1947 - 1983. New York: Rizzoli International Publications, 1989.

HEJDUK, JOHN. Victims: A Work. London: Architectural Association, 1986. 
HEJDUK, JOHN. Berlin Night. Berlin: Nederlands Architectuurinstituut, 1993.

HEJDUK, JOHN. Berlin Masque. Copy of Sketchbook. Center for Canadian Architecture, Montreal, Canada.

HOLL, STEVEN, PALLASMAA, JUHANI and PEREZ-GOMEZ, ALBERTO.

Questions of Perception: Phenomenology of Architecture. San Francisco: William Stout Publishers. 2006; originally published as special issue of a + u, July 1994.

HOLMES, JEAN. Times to Remember in Elzevir Township. Madoc: Madoc Printing, 1984.

INGOLD, TIM. Lines: A Brief History. Oxford: Routledge, 2007.

ISHIKAWA, SARA and SILVERSTEIN, MURRAY . A Pattern Language: Towns, Buildings, Construction. Oxford: Oxford University Press. 1977.

JOHNSTON, GEORGE. Carl: Portrait of a Painter. Newcastle Ontario: Penumbra Press. 1986.

KLEE, PAUL. Pedagogical Sketchbook. London: Faber and Faber, 1953.

KLEE, PAUL. Paul Klee On Modern Art. London: Faber Paper Cover Editions, 1966. 
KRUFT, HANNO-WALTER. History of Architectural Theory: From Vitruvius to the Present. London; New York: Zwemmer; Princeton Architectural Press. 1994.

KUMA, KENGO. Anti-Object. London: Architectural Association, 2008.

LEATHERBARROW, DAVID. Topographical Stories: Studies in Landscape and Architecture. Pittsburg: University of Pennsylvania Press, 2004.

LEATHERBARROW, DAVID and MOSTAFAVI, MOSHEN. On Weathering: The Life of Buildings in Time. Cambridge, MA: MIT PRESS, 1993.

LOOS, ADOLF. Spoken Into the Void: Collected Essays,1897-1900. Cambridge MA: MIT Press, 1982.

MANGUEL, ALBERTO. A History of Reading. London: Penguin 1996.

MALLGRAVE, HARRY FRANCIS. The Architect's Brain: Neuroscience, Creativity, and Architecture. Wiley-Blackwell, Chichester,West Sussex, UK. 2011.

NABAKOV, VLADIMIR. Speak Memory. London: First Vintage International Edition, 1989. 
NESBITT, KATE ed. The Tell-The-Tale Detail. New York: Princeton Architectural Press, 1996.

ODATE, TOSHIO. Japanese Woodworking Tools : Their Tradition, Spirit and Use. Fresno CA: Linden Publishing, 1998.

PONTY, MERLEAU C. The Primacy of Perception. Evanston Ill: Northwestern University Press, 1964.

QUANTRILL, MALCOLM and WEBB, BRUCE eds. Constancy and Change in Architecture. College Station Texas: Texas A\&M University Press, 1991.

RENDELL, JANE. Site Writing: The Architecture of Art Criticism. London: I.B. Tauris and Co, 2010.

RICOEUR, PAUL. History and Truth. Evanston Ill: Northwestern University Press. 1965

RICOEUR, PAUL. Time and Narrative. Chicago: The University of Chicago Press, 1983.

RICOEUR, PAUL. Memory, History and Forgetting. Chicago: The University of Chicago Press, 2004. 
RICOEUR, PAUL. The Rule of Metaphor: Multi-disciplinary Sutdies of the Creation of Meaning in Language. Trans. Robert Czerny. Toronto: University of Toronto Press. 1977.

RYKWERT, JOSEPH. The Necessity of Artifice. New York: Rizzoli. 1982.

RYKWERT, JOSEPH, On Adam's House in Paradise: The Idea of the Primitive Hut in Architectural History. Cambridge, MA: MIT Press. 1972.

RYKWERT, JOSEPH, The Dancing Column: On Order in Architecture. Cambridge, MA: MIT Press. 1999.

STONER, JILL. Toward a Minor Architecture. Cambridge, MA: MIT Press, 2012.

SUMMERS, DAVID. Real Spaces: World Art History and the Rise of Western Modernism. London: Phaidon Press. 2003.

TURNBULL, DAVID. Maps are Territories: Science is an Atlas a portfolio of exhibits. Chicago: The University of Chicago Press. 1989.

VARLEY, CHRISTOPHER. Carl Schaefer in Hanover. Edmonton : Art Gallery. 1980. 
VESELY, DALIBOR. Architecture in the Age of Divided Representation: the Question of Creativity in the Shadow of Production. Cambridge, MA: MIT Press. 2004.

VESELY, DALIBOR. "The Architectonics of Embodiment," in Dodds, Tavernor and Rykwert, Body and Building: Essays on the Changing Relation of Body and Architecture. Cambridge MA: MIT Press. 2002.

VITRUVIUS. Ten Books on Architecture, trans. Ingrid D. Rowland, Commentary and Illustrations by Thomas Noble Howe. Cambridge: Cambridge University Press. 1999.

ZUMTHOR, PETER. Thinking Architecture, trans. Maureen Oberli-Turner and Catherine Schelbert. Basel: Birhauser. 2006.

ZUMTHOR, PETER. Atmospheres: Architectural Environments - Surrounding Objects. Basel: Birhauser. 2006. 